\title{
Assessment of \\ Coal Gasification/Hot Gas Cleanup Based Advanced Gas Turbine Systems
}

Greenfield Assessment

Final Report

December 1991

Work Performed Under Contract No.: DE-FC21-89MC26019

For

U.S. Department of Energy

Office of Fossil Energy

Morgantown Energy Technology Center

Morgantown, West Virginia

By

Southem Company Services, Inc.

Research and Environmental Affairs

Birmingham, Alabama 


\section{DISCLAIMER}

This report was prepared as an account of work sponsored by an agency of the United States Government. Neither the United States Government nor any agency thereof, nor any of their employees, makes any warranty, express or implied, or assumes any legal liability or responsibility for the accuracy, completeness, or usefulness of any information, apparatus, product, or process disclosed, or represents that its use would not infringe privately owned rights. Reference herein to any specific commercial product, process, or service by trade name, trademark, manufacturer, or otherwise does not necessarily constitute or imply its endorsement, recommendation, or favoring by the United States Government or any agency thereof. The views and opinions of authors expressed herein do not necessarily state or reflect those of the United States Government or any agency thereof.

This report has been reproduced directly from the best available copy.

Available to DOE and DOE contractors from the Office of Scientific and Technical Information, P.O. Box 62, Oak Ridge, TN 37831; prices available from (615)576-8401, FTS 626-8401.

Available to the public from the National Technical Information Servise, U.S. Department of Commerce, 5285 Port Royal Rd., Springfield, VA 22161. 


\title{
Assessment of \\ Coal Gasification/Hot Gas Cleanup Based Advanced Gas Turbine Systems
}

Greenfield Assessment

Final Report

Work Performed Under Contract No.: DE-FC21-89MC26019

\author{
For \\ U.S. Department of Energy \\ Office of Fossil Energy \\ Morgantown Energy Technology Center \\ P.O. Box 880 \\ Morgantown, West Virginia 26507-0880
}

\section{By}

Southern Company Services, Inc.

Research and Environmental Affairs

P.O. Box 2625

Birmingham, Alabama 35202

December 1991 


\begin{abstract}
This document is a sequel to an earlier assessment of the characteristics of advanced gasification-based power plants. The previous report compared capital costs, electricity costs, and environmental performance of six different case studies of coal gasification having hot gas cleanup integrated with different advanced gas turbine cycles. The study was sponsored by the U.S. Department of Energy (DOE) Morgantown Energy Technology Center (METC) and Southern Company Services, Inc. The different case studies nere designed to be as specific as possible for The Southern Company, with all the studies conducted at Georgia Power's existing Plant Wansley. This report focuses on a Greenfield cost assessment for three of the cases.
\end{abstract}

Both the KRW fluidized-bed gasifier and the transport gasifier case studies were used for this assessment. The transport technology is a high-velocity circulating fluidized-bed reactor currently under development by The M.W. Kellogg Company. In the earlier assessment, seven design concepts or cases were identified; a process design was developed; major equipment items were identified; estimates of capital cost, operation and maintenance cost, and cost of electricity were developed; reliability was predicted; and development issues were identified for six studies. Three of the most probable cases were further evaluated for a Greenfield assessment in this report to adequately determine all costs independent of facilities at Plant Wansley.

The primary costs that were changed are general facility costs such as coal delivery, coal handling, limestone handling, land purchase costs. A cost of electricity analysis was performed to adequately compare the three most probable cases.

Greenfield cost of electricity for IGCC Cases 1,3 , and 6 increased only 3.46, 4.80, and 4.17 percent to $50.8 \mathrm{mills} / \mathrm{kWh}, 56.8 \mathrm{mills} / \mathrm{kWh}$, and $47.5 \mathrm{mills} / \mathrm{kWh}$ respectively. Total capital requirement for cases 1,3 , and 6 increased to $\$ 645.3$ million, $\$ 376.0$ million, and $\$ 554.0$ million, respectively, for the Greenfield assessment. 


\section{ACKNOWLEDGEMENTS}

The following are the major participants:

Principal Investigators, Authors, and Contributors:

Southern Company Services, Inc.

Maria Jeffers Burke, Research \& Environmental Affairs

Robert B. Hinshaw, Power \& Systems Engineering - Mechanical

Richard Hovey, Power \& Systems Engineering - Mechanical

Paul H. Walker, Cost/Schedule

Kenneth W. Boyd, Engineering Publications

J. Douglas Maxwell, Research \& Environmental Affairs

Frank J. Sciarabba, Engineering Services

\section{Program Management and Oversight:}

R. Daniel Brdar, U.S. Department of Energy, Morgantown Energy Technology Center (COTR)

Rod E. Sears, Southern Company Services, Inc., Research \& Environmental Affairs 


\section{TABLE OF CONTENTS}

1.0 INTRODUCTION $\ldots \ldots \ldots \ldots \ldots \ldots \ldots \ldots \ldots \ldots \ldots \ldots \ldots$

2.0 CASE SELECTION FOR GREENFIELD ASSESSMENT . . . . . . . . 2-1

2.1 IGCC Cases Studies in Original Report . . . . . . . . . . . . 2-1

2.1.1 Case 1: 400-MW Air-Blown IGCC with Hot Gas Cleanup . . . 2-2

2.1.2 Case 2: 100-MW ISTIG . . . . . . . . . . . . . 2-2

2.1.3 Case 3: 200-MW Air-Blown IGCC with Hot Gas Cleanup . . . 2-2

2.1.4 Case 4: 400-MW ISTIG . . . . . . . . . . . . . . 2-5

2.1.5 Case 5: 400-MW IGCC with Bulk External

Desulfurization . . . . . . . . . . . . . . . . . 2-5

2.1.6 Case 6: 400-MW IGCC with Transport Gasifier and Sulfator . 2-5

2.1.7 Case 7: 400-MW IGCC with Mild Gasification, Transport

Reactors . . . . . . . . . . . . . . . . . . 2-8

2.2 Original Plant Performance and Cost Results . . . . . . . . . . . 2-8

2.2.1 Performance of the Original Six Cases ........... . 2-10

2.3 Overall Objectives ........................ 2-13

3.0 ADDITIONS TO GENERAL SITE CRITERIA FOR GREENFIELD

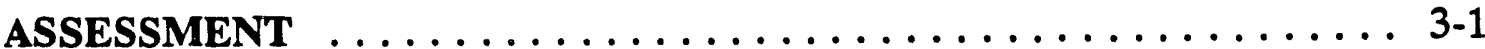

3.1 Greenfield Siting Assumptions . . . . . . . . . . . . . . 3-1

3.2 Site Preparation Requirements and Land Costs . . . . . . . . . 3-2

3.3 Water Supply Costs . . . . . . . . . . . . . . . . . . 3-9

3.4 Coal Handling Requirements . . . . . . . . . . . . . . . 3-9

3.4.1 Coal Handling Specifications . . . . . . . . . . . . . . . 3-9

3.4.2 Limestone Receiving, Storage, and Handling . . . . . . . . . . 3-10

3.5 Transportation, Road, and Railway Facilities . . . . . . . . . . 3-10

3.6 Ash Disposal Facilities . . . . . . . . . . . . . . . . . . . 3-11

3.7 Additional Miscellaneous Costs ................. 3-11

4.0 ENVIRONMENTAL HEALTH AND SAFETY AND SOCIOECONOMIC

ASSESSMENT ........................ 4-1

4.1 Environmental Permitting Process and Compliance Plan . . . . . . . . 4-1

4.1.1 Air Emissions . . . . . . . . . . . . . . . . . . . 4 4-1

4.1.1.1 Emissions Control ... . . . . . . . . . . . . 4-2

4.1 .1 .2 Modeling . . . . . . . . . . . . . . . . 4-2

4.1.1.3 Minor Constituents . . . . . . . . . . . . . . . . 4 4-4

4.1 .2 Waste Solids Disposal . . . . . . . . . . . . . . . . . . 4 4

4.1.3 Water Consumption Permits ................ 4-5

4.1.4 Water Discharge Permitting ................ 4-5

4.1 .5 Miscellaneous Permitting .................. 4-6

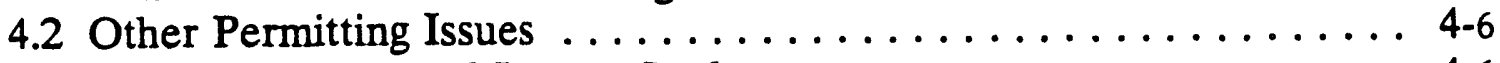

4.2.1 Environmental Impact Study . . . . . . . . . . . . 4 4-6

4.2.2 Endangered Species ................. . . . . . . 
Assessment of Coal Gasification/Hot Gas

Cleanup Based Advanced Gas Turbine Systems

4.2.3 Noise Survey $\ldots \ldots \ldots \ldots \ldots \ldots \ldots \ldots \ldots \ldots \ldots \ldots \ldots, 4,9$

4.2.4 Wetlands Evaluation .................. 4- 9

4.2.5 Archaeological Survey . . . . . . . . . . . . . . 4. 9

4.2.6 Health and Safety .................... 4- 9

4.2.7 Socioeconomic Impacts $\ldots \ldots \ldots \ldots \ldots \ldots \ldots \ldots \ldots$ 4- 10

5.0 CAPITAL AND OPERATING COST ESTIMATES $\ldots \ldots \ldots \ldots \ldots \ldots$ 5-1

5.1 Capital Cost Estimates . .................... 5-1

5.1.1 Estimating Assumptions and Procedures $\ldots \ldots \ldots \ldots \ldots$ 5-1

5.1 .2 Capital Cost Results . . . . . . . . . . . . . . . . 5-6

5.2 Operating and Maintenauce Cost Estimates ............ 5-13

5.2.1 Estimating Assumptions and Procedures $\ldots \ldots \ldots \ldots \ldots$ 5-13

5.2.2 Total and Net O\&M Cost Results . . . . . . . . . . . 5-17

5.3 Cost of Electricity Determination . . . . . . . . . . . . . 5-20

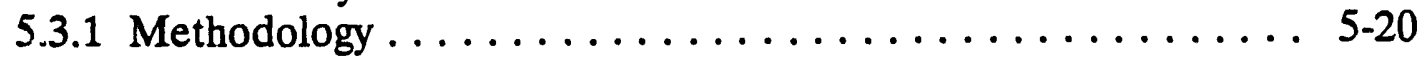

5.3 .2 Assumptions . . . . . . . . . . . . . . . 5.20

5.3.3 Summary: Total Costs of Electricity $\ldots \ldots \ldots \ldots \ldots \ldots, 5-22$

6.0 CONCLUSIONS AND RECOMMENDATIONS $\ldots \ldots \ldots \ldots \ldots \ldots$.

REFERENCES $\ldots \ldots \ldots \ldots \ldots \ldots \ldots \ldots \ldots \ldots \ldots \ldots \ldots \ldots \ldots \ldots$ R-1

ACRONYMS AND ABBREVIATIONS $\ldots \ldots \ldots \ldots \ldots \ldots \ldots \ldots$ AC-1

\section{APPENDIX A}

PLANT DESCRIPTION AND DETAILS - CASES 1, 3, and $6 \ldots \ldots \ldots$ A-1

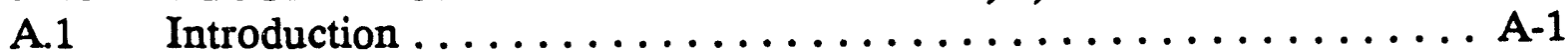

A.2. Air-Blown IGCC with KRW Gasification, Bulk Sulfur Removal in the Gasifier (Cases 1 and 3) . . . . . . . . . . . . . . . A-1

A.2.1 Process Description ..................... A-1

A.2.1.1 Overall Process Arrangement ............. A-1

A.2.1.2 Coal and Limestone Receiving, Handling, and

Preparation .................... A-12

A.2.1.3 Air Compression and Supply ............ A-15

A.2.1.4 Coal Gasification and Recycle Gas Compression ... A-16

A.2.1.5 Gas Conditioning ................. A-23

A.2.1.6 External Desulfurization ............... A-23

A.2.1.7 Gasifier Solids Sulfation .............. A- 24

A.2.1.8 Gas Turbine System ................ A- 31

A.2.1.9 HRSG System ................. A- 31

A.2.1.10 Steam Turbine System $\ldots \ldots \ldots \ldots \ldots \ldots \ldots$ A- 34

A.2.1.11 Ash Handling and Disposal $\ldots \ldots \ldots \ldots \ldots \ldots$ A- 34

A.2.1.12 General Facilities ................ A- 36

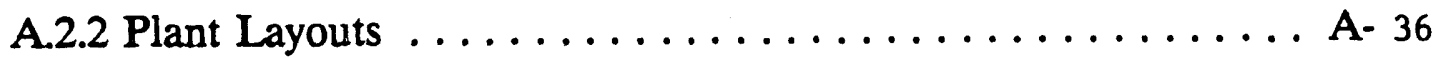

A.3 400-MW IGCC with Transport Gasifier (Case 6) . . . . . . . A A 40 
A.3.1 Process Discussion ...................... A. 40

A.3.1.1 Overall Arrangement ................. A. 40

A.3.1.2 Coal and Limestone Receiving, Handling, and Preparation ..................... A. 50

A.3.1.3 Air Compression and Supply ............. A. 52

A.3.1.4 Coal Gasification and Recycle Gas Compression ... A. 52

A.3.1.5 Gas Conditioning .................. A. 56

A.3.1.6 Gasifier Solids Sulfation . . . . . . . . . . . A. 59

A.3.1.7 Gas Turbine System ................ A. 60

A.3.1.8 HRSG System .................... A. 60

A.3.1.9 Steam Turbine System ................. A. 64

A.3.2 Plant Layout $\ldots \ldots \ldots \ldots \ldots \ldots \ldots \ldots \ldots \ldots \ldots \ldots \ldots \ldots \ldots \ldots \ldots$

A.4 IGCC PLANT OPERATIONS AND PERFORMANCE

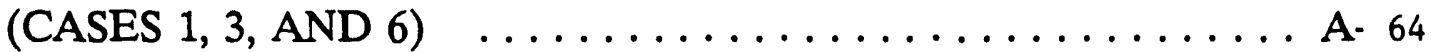

A.4.1 Plant Equipment and Supplies ............... A. 64

A.4.1.1 Spare Equipment and Material................ A- 64

A.4.1.2 Catalysts and Chemicals ................ A. 64

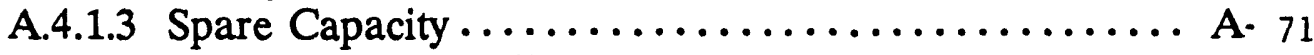

A.4.1.4 Equipment Reliability $\ldots \ldots \ldots \ldots \ldots \ldots \ldots$ A. 72

A.4.2 Process Performance ................... A. 72

A.4.2.1 Heat and Material Balances .............. A- 72

A.4.2.2 Gasifier Island Performance and Interfaces ...... A. 73

A.4.2.3 Power Island Performance . . . . . . . . . . A. 73

APPENDIX B

DETAILED COST OF ELECTRICITY RESULTS FOR GREENFIELD B-1

ASSESSMENT (DOE MODEL) CASE 1, 3, AND 6 


\section{LIST OF FIGURES}

2-1 Simplified Schematic of the System Configuration for IGCC Cases 1 and 3 . 2-3

2-2 Simplified Schematic of the System Configuration for ISTIG Cases 2 and 4 2-4

2-3 Simplified Schematic of the System Configuration for IGCC Case $5 \ldots \ldots$ 2-6

2-4 Simplified Schematic of the System Configuration for IGCC Case $6 \ldots \ldots$. . 2-7

2-5 Simplified Schematic of the System Configuration for IGCC Case $7 \ldots \ldots$ 2-9

3-1 Greenfield General Arrangement for IGCC Case $1 \ldots \ldots \ldots \ldots \ldots$. . . . . . .

3-2 Greenfield General Arrangement for IGCC Case $3 \ldots \ldots \ldots \ldots . . \ldots$ 3-5

3-3 Greenfield General Arrangement for IGCC Case $6 \ldots \ldots \ldots \ldots \ldots$. . . . . . .

4-1 Solid Waste Landfill Location for Case $1 \ldots \ldots \ldots \ldots \ldots \ldots . \ldots . \ldots .7$

5-1 Capital Cost of all Cases by Cost Element ............... 5-11

5-2 Process Plant Cost Component Comparison ............... 5-12

5-3 Comparison of O\&M Cost Components . . . . . . . . . . . . . 5-19

5-4 Cost of Electricity by Components for Gasification-Based Power Plants . . 5-24

5-5 Cost of Electricity Comparison to Siie-Specific Study . . . . . . . . 5-25 


\section{LIST OF TABLES}

2-1 Primary System Components and Parameters for the Study Cases . . . . . . 2-1

2-2 Summary of Gasification Power Plant Performance $\ldots \ldots \ldots \ldots \ldots$ 2-10

2-3 Summary of Gasification Power Plant Costs . . . . . . . . . . 2-12

4-1 ISCST Model Predicted Impacts of IGCC Plants on Air Quality . . . . . . 4-3

5-1 Capital Cost Summary: Mid-1990 Dollars ............... 5-7

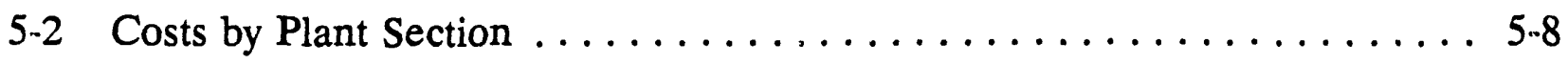

5-3 Breakdown of Owners Costs: Mid-1990 Dollars . . . . . . . . . . . 5 5-9

5-4 Major Unit Costs for Annual O\&M Items $\ldots \ldots \ldots \ldots \ldots \ldots \ldots$ 5-13

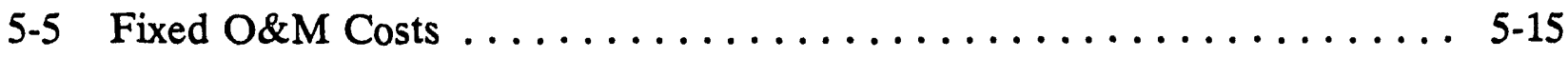

5-6 Maintenance Material Cost as Percentage of Process Plant Cost by Area . 5-16

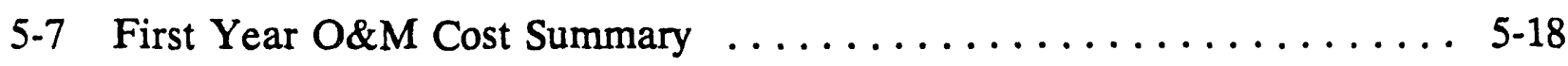

5-8 Base Case Economic Assumptions for Cost of Electricity Calculation ... 5-21

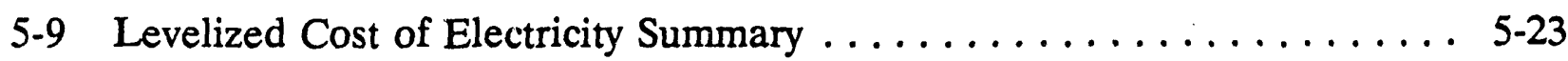




\subsection{INTRODUCTION}

The Southern Company is one of the nation's largest investor-owned electric utility systems, supplying energy to approximately 10 million people across the Southeastern United States. The Southern Company is the parent firm of five electric utilities: Alabama Power Company, Georgia Power Company, Gulf Power Company, Mississippi Power Company, and Savannah Electric and Power Company. Southern Company Services, Inc., (SCS) provides engineering, research, and technical support for the five utilities. The companies of The Southern Company represent over \$18 billion in assets and over 30,000 MW of generating capacity, of which approximately 80 percent is coal fired.

The current expansion plan for The Southern Company estimated that the next baseload generation would be added in 2006. Between 1995 and 2006, more than $6000 \mathrm{MW}$ of peaking, storage, and intermediate-capacity generation was projected to be added; however, the great uncertainty in the availability and prices of oil and natural gas was also a major concern. Options being considered to supply peaking fuels in the event of a major oil shortage included stockpiling petroleum and direct production of synthetic fuels from coal.

In addition, the increasing emphasis on combustion turbines in The Southern Company generation expansion plan, along with concerns about their fuel supply, focused attention on coal gasification as a means of deriving premium fuels from coal. Moreover, integrated gasification combined cycle (IGCC) is viewed as a potentially attractive technology for baseload expansion. IGCC plants also have the potential to produce methanol for use as a peaking fuel. IGCC plants are highly efficient, have a relatively low operating cost, and have the best environmental performance of any coal-fired plants. A site-specific study conducted by SCS for the Electric Power Research Institute (EPRI) indicated that an IGCC plant based on a KRW gasifier could be a competitive baseload power generation technology compared to a baseload pulverized-coal-fired unit.(1)

To further investigate the effects of air-blown IGCC power plants with hot gas cleanup, SCS entered into a follow-on site-specific study with the U.S. Department of Energy (DOE) Morgantown Energy Technology Center (METC).(2) The focus of the December 1990 study of various power plant configurations was to determine whether air-blown gasification with hot gas cleanup is competitive against either oxygen-blown IGCC with cold gas cleanup or a conventional pulverized-coal-fired plant. 'The study included investigating the effects that different power island configurations, plant sizes, methods of sulfur removal, and gasifier types had on the design and costs of the air-blown gasification-based power plant with hot gas cleanup. As in the previous EPRI IGCC study, the airblown gasification power plants were assumed to be located at Plant Wansley. 
To get a more generalized cost estimate for air-blown gasification, DOE/METC requested additional information from the December 1990 study which would estimate Greenfield costs for the most probable cases. Three case studies were selected, all being air-blown gasification with in-bed hot gas sulfur cleanup, and an established GE MS7001F turbine. The focus of the additional study was the additional general facilities and operation and maintenance (O\&M) costs. No technical assumptions associated with the gasifier or power islands were changed for this report. 


\subsection{CASE SELECTION FOR GREENFIELD ASSESSMENT}

\subsection{OVERALL OBJECTIVES}

The major objective of this follow up report of air-blown gasification power plants with hot gas cleanup is to evaluate and compare three power plant configurations to determine a Greenfield cost estimate for an air-blown gasification-based power plant with hot gas cleanup.

Three of the seven previously evaluated design concepts were selected for the study to accomplish the overall objectives.

\subsection{IGCC CASES STUDIES IN ORIGINAL REPORT}

This section is given as background information from the December 1990 DOE report concerning the six original IGCC case studies developed. Each case study differed in either gasifier technology, sulfur cleanup method, size of capacity, or turbine generator size. Table 2-1 outlines the original six cases and how they differed. A summary paragraph about each original case study and the seventh case (not actually developed) is included in this section.

Table 2-1

Primary System Components and Parameters for the Study Cases

\begin{tabular}{|c|c|c|c|c|c|c|}
\hline \multirow[b]{2}{*}{ CASE } & \multirow{2}{*}{$\begin{array}{l}\text { GASIFIER } \\
\text { TYPE }\end{array}$} & \multirow{2}{*}{$\begin{array}{l}\text { NOMINAL } \\
\text { PLANT } \\
\text { SIZE(MW) }\end{array}$} & \multirow[b]{2}{*}{ CYCLE } & \multicolumn{2}{|c|}{ SULFUR CLEANUP } & \multirow[b]{2}{*}{ FEATURES } \\
\hline & & & & $\overline{\text { IN-BED }}$ & ZINC FERRITE & \\
\hline 1 & $\mathbf{K R W}$ & 400 & IGCC $^{1}$ & YES & POLISHING & \\
\hline 2 & KRW & 100 & iSTIG ${ }^{2}$ & YES & POLISHING & $\mathrm{LM}=8000 \mathrm{CT}^{3}$ \\
\hline 3 & KRW & 200 & IGCC & YES & POLISHING & \\
\hline 4 & $\mathbf{K R W}$ & 400 & ISTIG & YES & POLISHING & LM8000 CT \\
\hline 5 & KRW & 400 & IGCC & No & BULK & $\mathrm{H}_{2} \mathrm{SO}_{4}$ PLANT \\
\hline 6 & TRANSPORT & 400 & IGCC & YES & NONE & HYBRID \\
\hline 7 & TRANSPORT & 400 & IGCC & YES & NONE & $\begin{array}{c}\text { MILD } \\
\text { GASIFICATION }\end{array}$ \\
\hline
\end{tabular}

1. Integrated gasification combined-cycle

2. Integrated steam injected gas turbine

3. Combustion turbine 


\subsubsection{Case 1: 400-MW Air-Blown IGCC With Hot Gas Cleanup}

This system configuratio 7 represented the base case design and consisted of a nominally 400-MW powes plant with air-blown, KRW fluidized-bed gasifiers employing in-bed desulfurization. Figure 2-1 presents a simplified schematic of the system configuration. The system included two heavy-duty GE MS7001F industrial gas turbines $\left(2300^{\circ} \mathrm{F}\right.$ firing temperature) coupled with one reheat steam turbine bottoming cycle. Spent limestone and ash from the gasifier were oxidized in an external sulfator prior to disposal.

The hot gas cleanup system consisted of hot particulate removal followed by hot gas desulfurization. Hot particulate removal consisted of a cyclone followed by an absolute, ceramic-candle-type filter. Gas temperatures were maintained at approximately $1000^{\circ} \mathrm{F}$. Solids collected in the particulate-capture equipment were sent to the external sulfator prior to disposal. Supplemental hot gas desulfurization was accomplished by means of a fixed-bed zinc ferrite system for sulfur polishing, or removal of a final increment of sulfur not easily removed in the fluidized bed. Regeneration off-gas from the polishing desu.furization system was recycled to the gasifier for in-bed sulfur capture.

\subsubsection{Case 2: 100-MW Intercooled Steam Injected Gas Turbine (ISTIG)}

The gasifier island portion of this system was similar in configuration to the system described in Case 1. The power island was based on a GE aeroderivative ISTIG turbine rather than the industrial turbine used in Case 1; however, in this case, only one train of gasification was employed, so that the total power output is reduced to the range of $100 \mathrm{MW}$. Due to the use of an ISTIG, the steam turbine cycle was eliminated and steam from the heat recovery steam generator (HRSG) is used as a reactant in the gasifier and for power generation in the gas turbine. Additionally, the high-pressure steam system is eliminated in this case. A simplified block flow diagram of the system configuration is given in Figure 2-2.

\subsubsection{Case 3: 200-MW Air-Blown IGCC With Hot Gas Cleanup}

The configuration for Case 3 was identical to that in Case 1 with the exception of the number of trains of gasification, cleanup, and gas turbine power generation. The primary objective of examining this case was to evaluate the effect of plant size on the cost of air-blown gasification with hot gas cleanup. This system was based on a single advanced GE MS7001F gas turbine, and therefore is the minimum size IGCC configuration possible with this turbine. Despite the small size of this plant, a reheat steam cycle is available and has been used. The gasification configuration is identical to that in Case 1. 


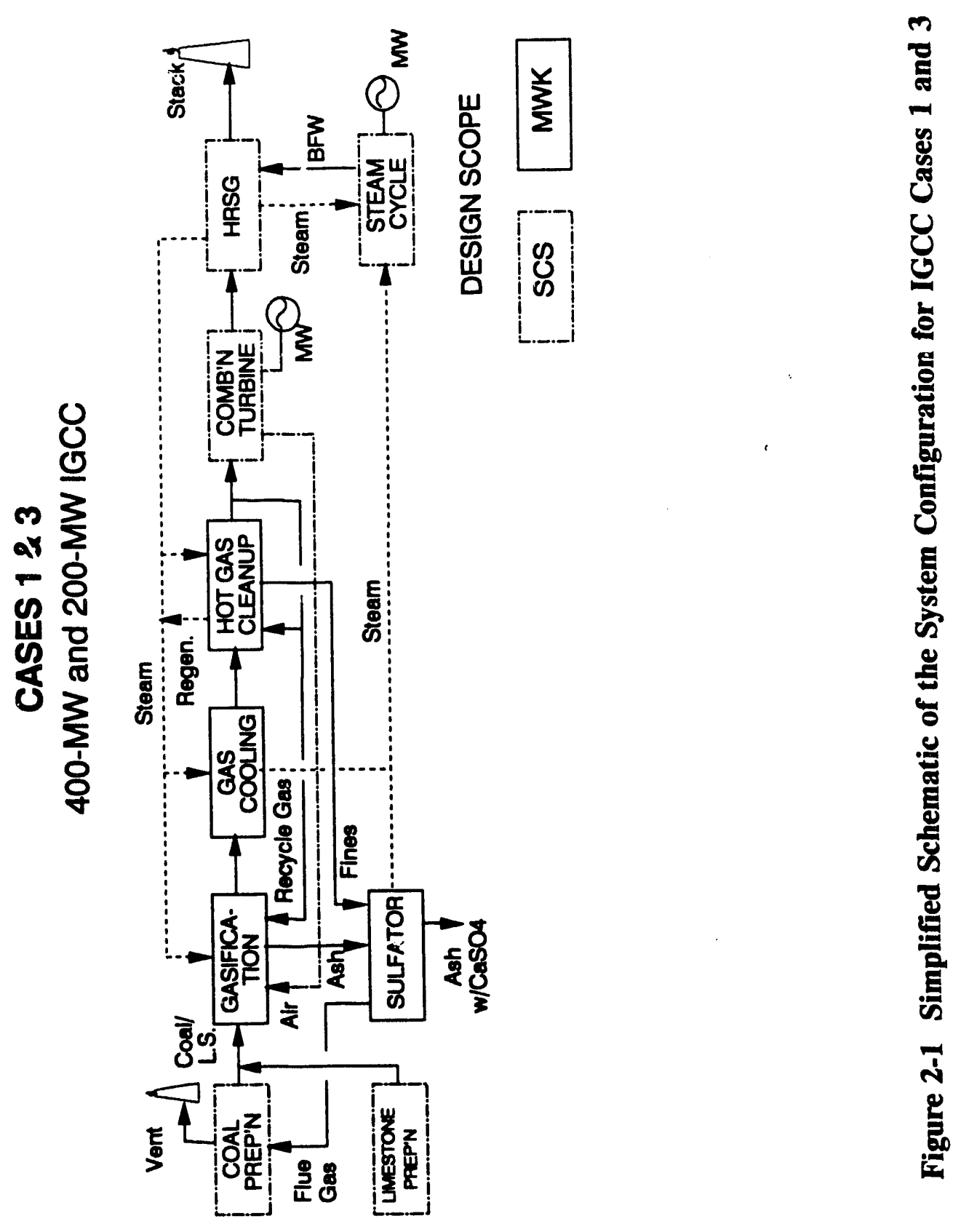




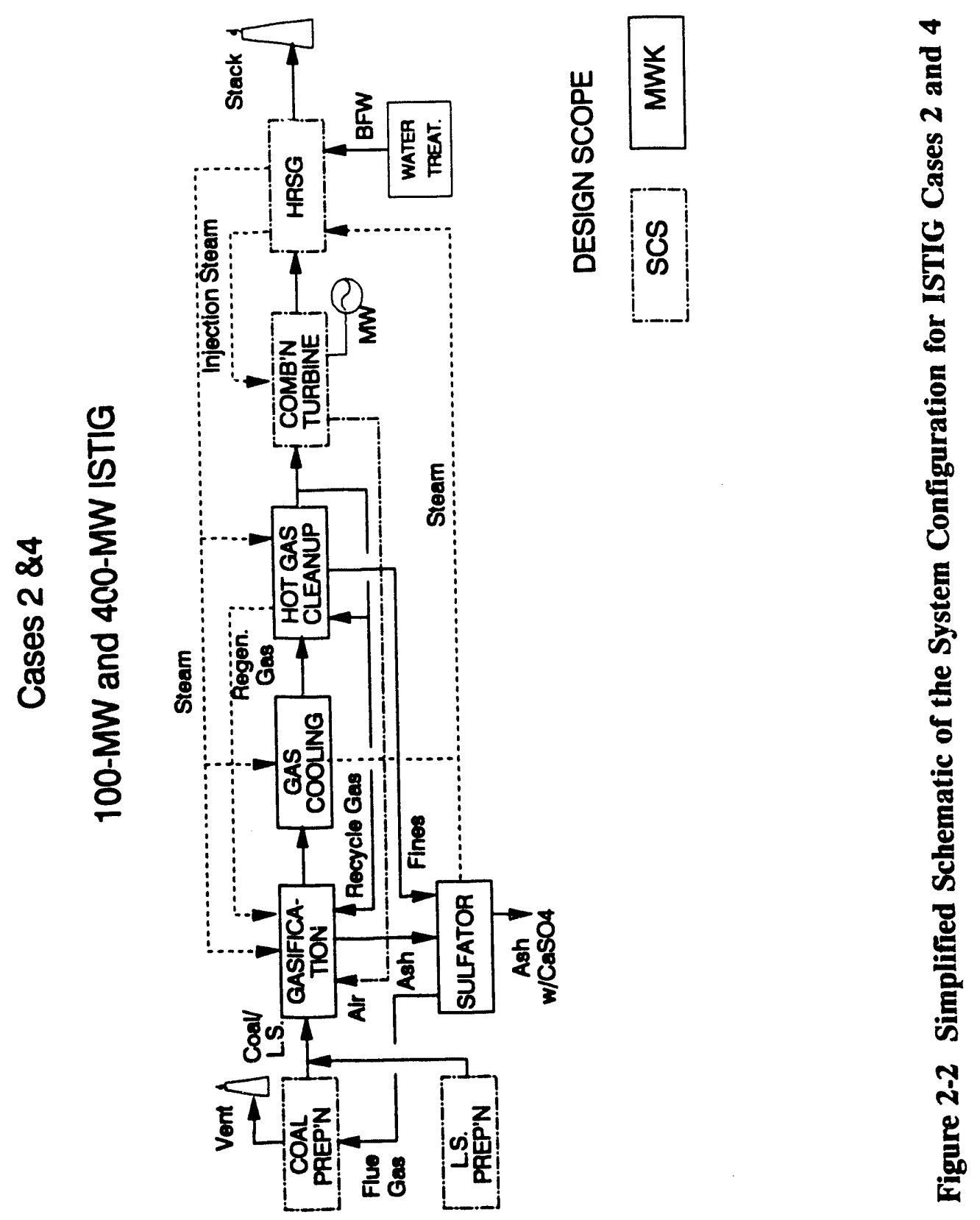




\subsubsection{Case 4: 400-MW ISTIG}

For this case, four GE ISTIG trains were powered by a fluidized-bed gasification system configured as in Case 2. The total power output of this plant was a nominal $400 \mathrm{MW}$, and therefore this case compared closely to the base case. This configuration was a modular scaleup of Case 2 with respect to the gasification and combustion turbine systems, with a total of four trains each equivalent to the single train of Case 2.

\subsubsection{Case 5: 400-MW IGCC with Bulk External Desulfurization}

The configuration for this case was similar to the base case except that desulfurization with limestone in the KRW fluidized-bed gasifier was eliminated. Bulk fuel gas desulfurization was done externally by zinc ferrite. In this design, a sulfuric acid plant was added to treat the zinc ferrite regeneration gas, producing sulfuric acid as a saleable byproduct. Because of the elimination of in-bed desulfurization with limestone, no sulfator vessel was required. The power island design for this case is essentially the same as that in the base case. Figure 2-3 illustrates the overall system configuration for Case 5.

\subsubsection{Case 6: 400-MW IGCC with Transport Gasifier and Sulfator}

Case 6 was similar to Case 1 except that the KRW fluidized-bed gasifier was replaced with a Kellogg circulating-bed gasifier. This gasifier operated at gas velocities which extend beyond those necessary for fluidization into the regime of particle transport or pneumatic conveying, and thus was termed a "transport" reactor. The system configuration illustrated in Figure 2-4 included a pressurized transport sulfator which was fed with char/ash from the gasifier. The transport gasifier operates with in-bed desulfurization by limestone. Because of the small coal and limestone particle sizes, sulfur capture was very rapid in the gasifier, and high levels of sulfur removal are obtained. Therefore, no external zinc ferrite system was required for this case, and consequentially chloride guard beds were eliminated. With respect to the power island, the flowsheet for Case 6 is similar to that described for Case 1. It is important to note that the transport reactor is still in the conceptual design phase of development. 


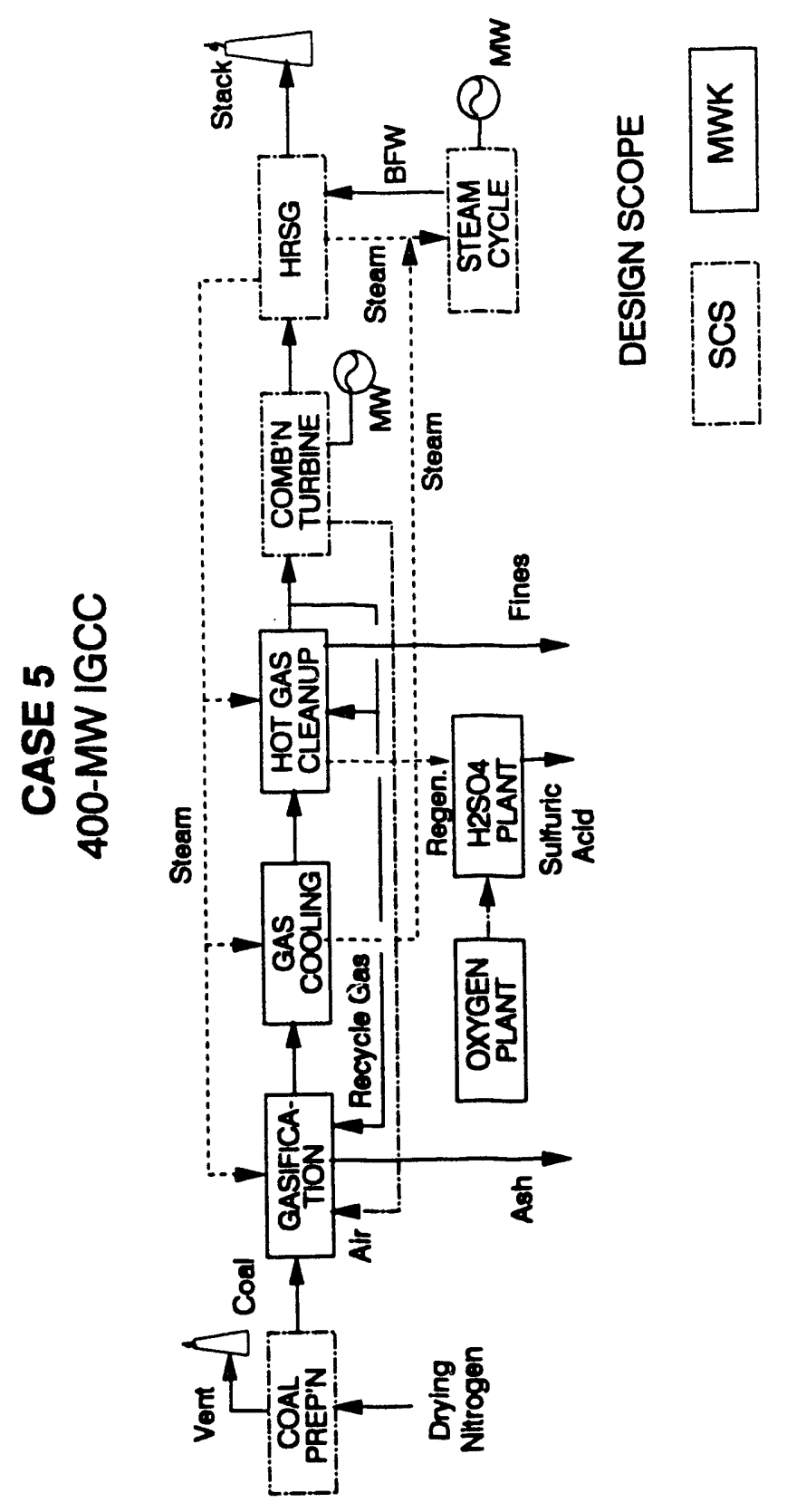

U 


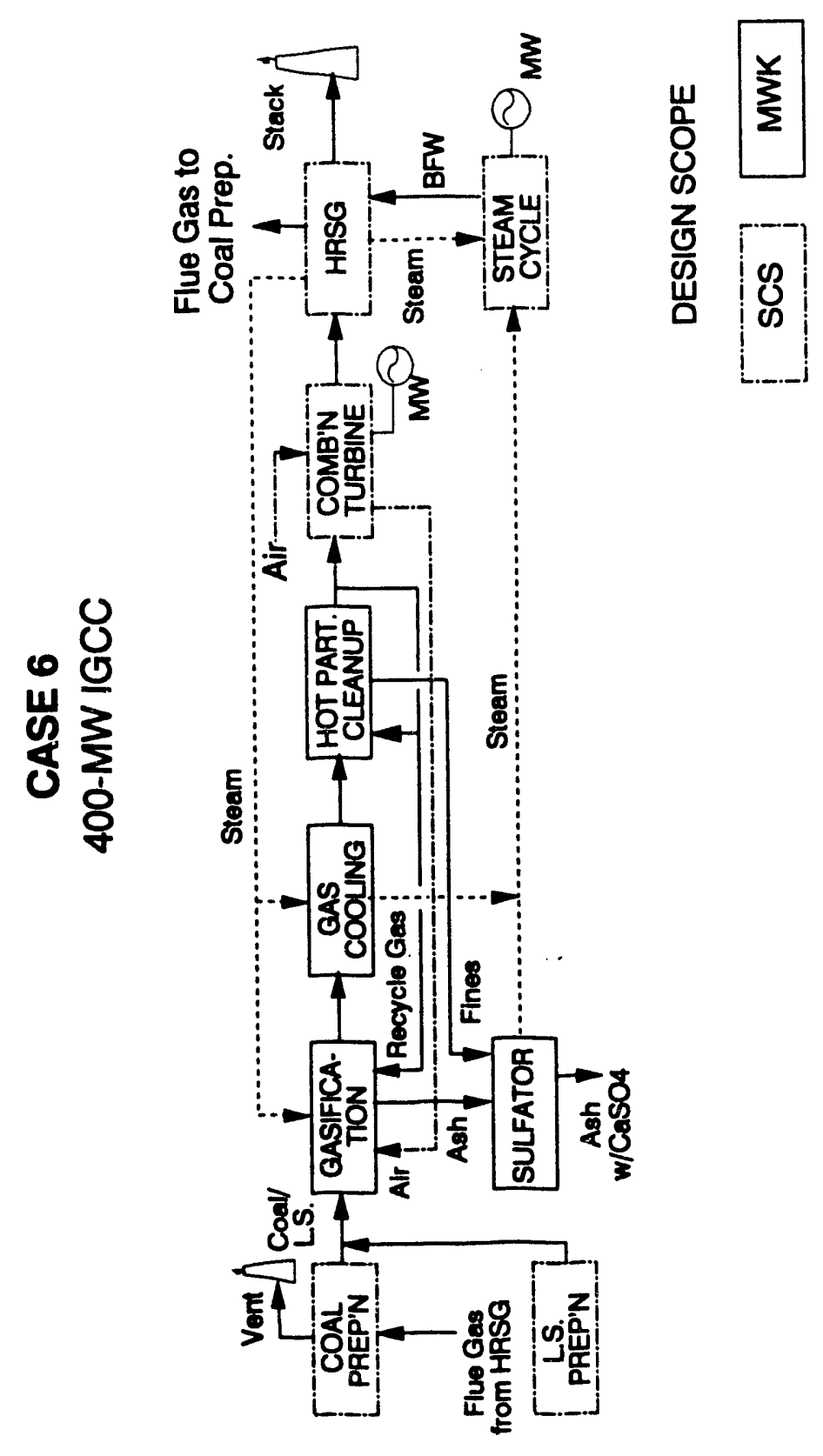

ป 


\subsubsection{Case 7: 400-MW IGCC with Mild Gasification, Transport Reactors}

The final case was similar to Case 6 with the addition of a mild gasification upstream of the char gasifier, as shown in the simplified system configuration for Case 7 in Figure 2-5. The char produced in the mild gasifier was used as the gasifier feed and the liquid product was stored for peaking turbine fuel. As in Case 6, the gasifier was a Kellogg transport design rather than the KRW fluidized-bed type. A transport sulfator was included to oxidize the ash produced by the gasifier. Again, no external zinc ferrite system was required for final sulfur polishing. The power island portion of this plant was based on the GE MS7001F advanced industrial combustion turbine and a reheat steam bottoming cycle, as in the base case. This case, however, was not considered to be technically feasible and therefore no detailed design was conducted in the original report.

\subsection{ORIGINAL PLANT PERFOPMANCE AND COST RESULTS}

The original study compared several primary parameters and system components for the six study cases.

Table 2-2 is a summary of the features and performance of the cases addressed in the study. Also included for comparison is an updated oxygen-blown case with conventional cold gas cleanup. The oxygen-blown case is based on a prior sitespecific study conducted by Southern Company Services with EPRI co-funding (1). Among the DOE cases, the best performance was achieved by the transport IGCC (Case 6), which uses a cycle that includes both gasification and pressurized combustion, called a hybrid cycle. The heat rate of $8153 \mathrm{Btu} / \mathrm{kWh}$ (HHV) for this case would be better than virtually any other coal-fired plant (generating only electric power) currently in existence. This performance compares to heat rates ranging from 8595 to 9357 design. The substantial performance advantage of this case over the KRW-based designs is attrik atable in large measure to the high cold gas efficiency predicted for the transpcit gasifier (82.1 percent vs 70 percent), which is due in turn to the good gasification kinetics and the low reactor temperature. Therefore, Case 6 was selected for the Greenfield assessment.

While the transport IGCC case appears to be very attractive for future consideration, this case is by far the least developed of the IGCC technologies addressed in the study. Although the transport is conceptual in status, the potential reductions in costs and heat rate justify further testing at a proof-ofconcept scale to demonstrate the technology. 


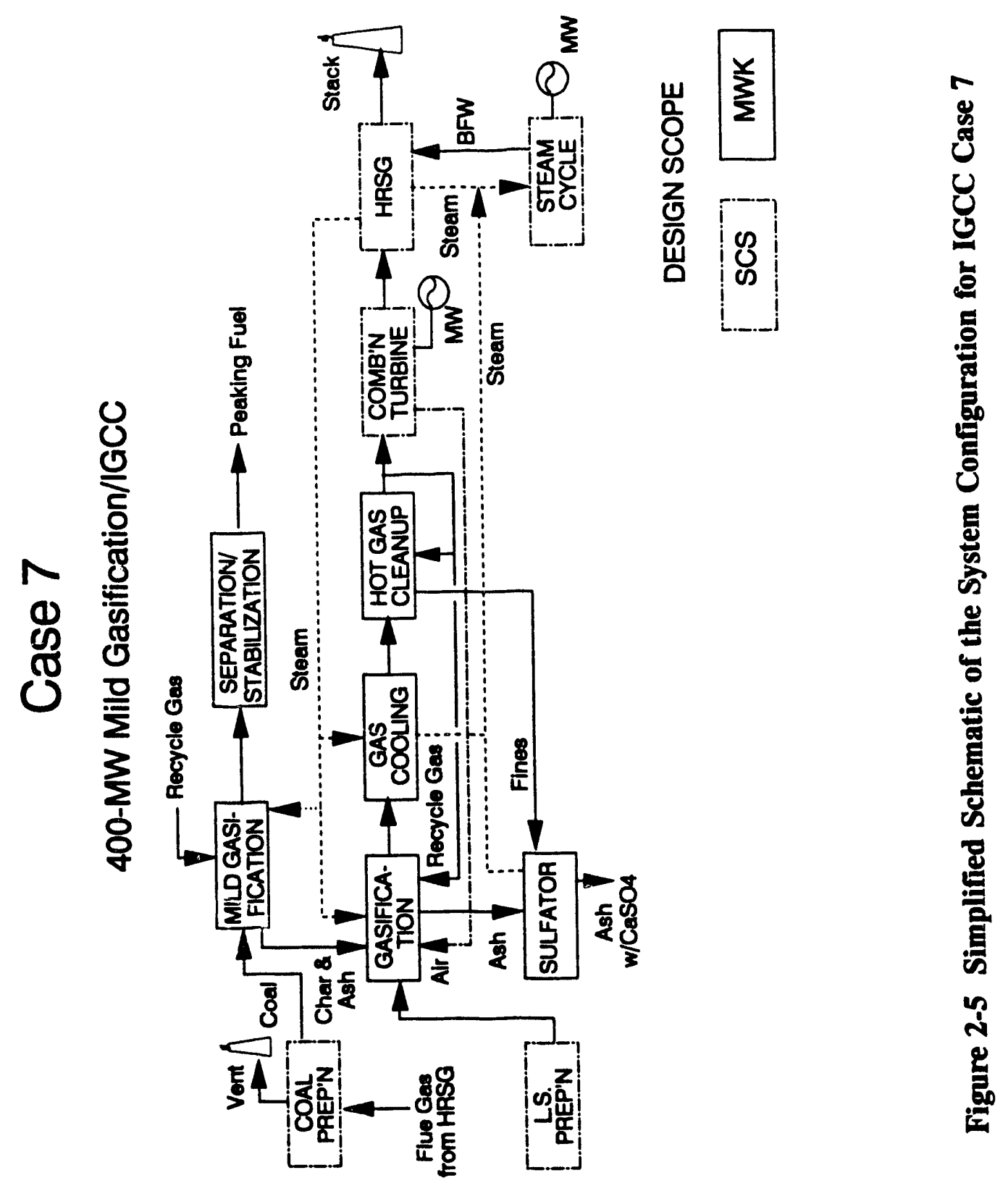


Assessment of Coal Gasification/Hot Gas

Cleanup Based Advanced Gas Turbine Systems

Table 2-2

Summary of Gasification Power Plant Performance

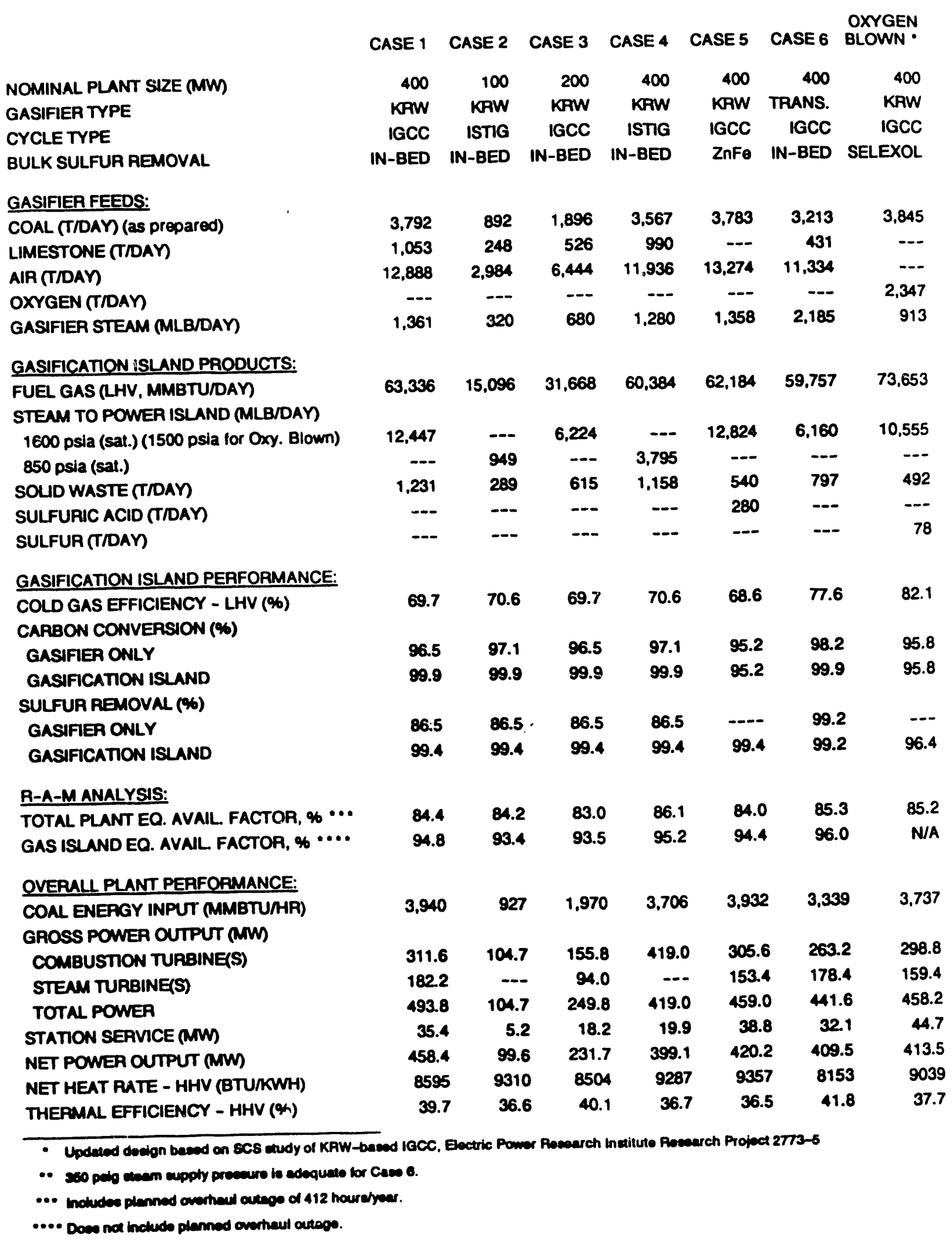


With regard to the relative costs of the IGCC cases (Table 2-3), transport IGCC again has a substantial advantage due to both high efficiency and low capital cost. The capital cost advantage, like high efficiency, stems from superior gasification and desulfurization performance assumed for the transport reactor, which reduces reactor size and eliminates the need for external desulfurization. Cornparing Case 1 with the reference case, air-blown gasification with hot gas cleanup is projected to have a 9-percent advantage in cost of electricity over oxygen-blown IGCC. An important conclusion of this study is that the major advantage of the Case 1 plant may be a substantial reduction in capital cost, amounting to 13 percent versus the oxygen-blown plant. Thus Case 1 was also selected for the Greenfield assessment.

A true capital cost savings would probably be of greater importance than operating cost advantages for The Southern Company. In particular, operating cost advantages arising from byproduct sales, as in the oxygen-blown reference case and DOE Case 5, would not be viewed as favorably as capital-derived savings because of market risks and added operating complexity.

Based on the current study, full hat gas cleanup using fixed beds of zinc ferrite sorbent coupled with sulfuric acid production (Case 5) would not appear to be an attractive IGCC alternative. Complete reliance on a zinc ferrite desulfurization system would not be acceptable to The Southern Company at the current level of development. Moreover, the higher capital cost and overall plant complexity for this case do not apply well to The Southern Company system. Because Case 5 had a higher cost of electricity in the original report, it was not considered for the Greenfield evaluation. Potential improvenients in this technology, some of which are outlined in Appendix A, must be pursued if this plant design is to gain widespread acceptance.

With regard to scale economies, Cases 1 and 3 provide an excellent indication of how plant scale affects both capital and operating costs, since Case 3 is essentially a half-scale version of Case 1 . The conclusion from this analysis is that the capital-cost scale economies over this size range are rather low (proportional to size in megawatts raised to the power of 0.8 ), which is a reasonable conclusion for highly modular technologies. Nonetheless, smaller plants would not be of significant interest for The Southern Company because of the large growth increments of the 30,000-MW system. However, in an effort to determine the effect of plant size on a Greenfield basis, Case 3 was also selected for this assessment.

The ISTIG cases developed in the project were of more interest to DOE than to SCS. The advantages cited for this cycle include higher efficiencies and reduced capital costs due to elimination of the steam turbine cycle. These advantages were not seen in the current study, as noted in Tables 2-2 and 2-3. The ISTIG cases were less efficient than expected because of a limitation in the ability of the 


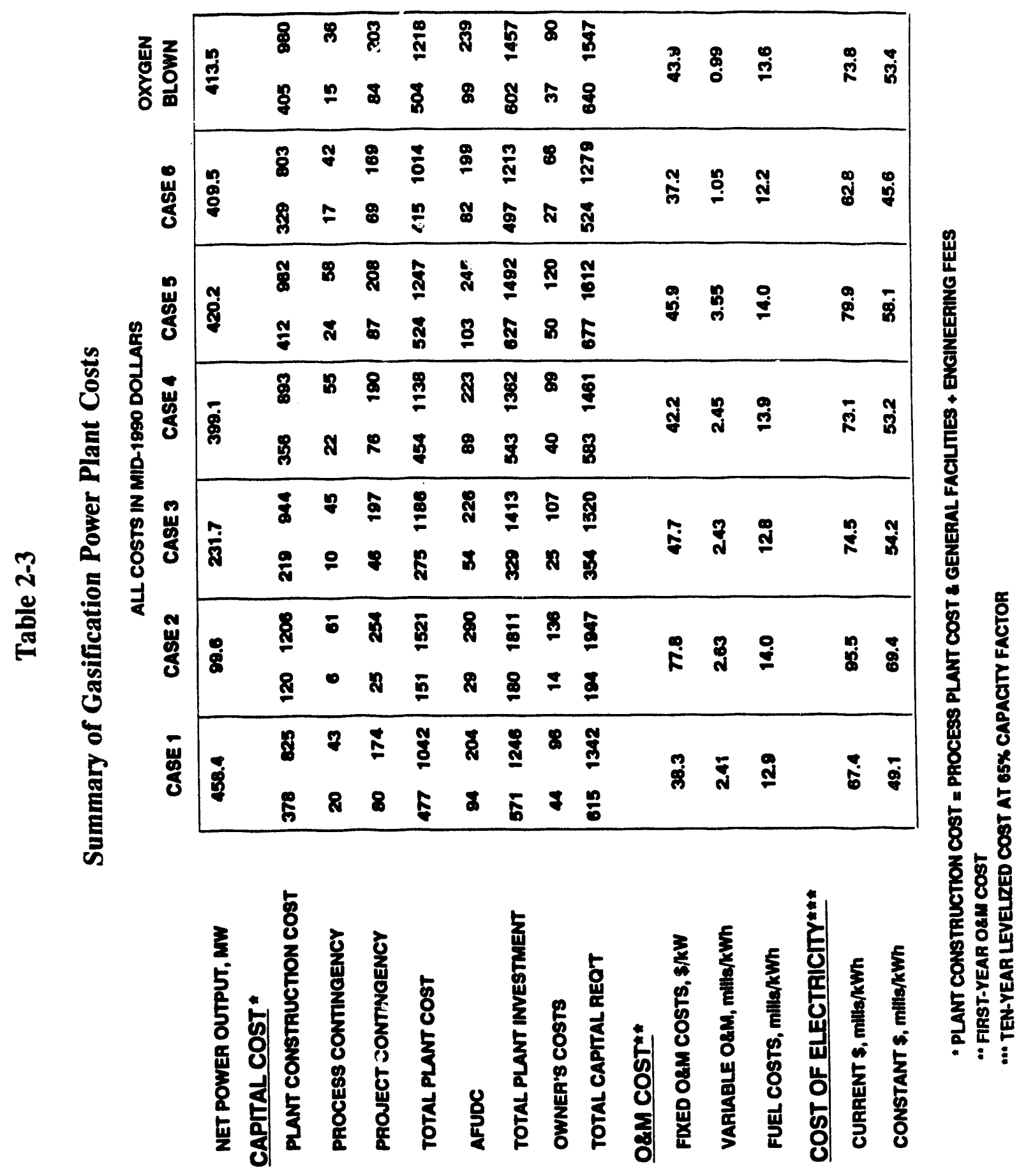


LM-8000 aeroderivative gas turbine to accommodate the full steam raising potential of the gasification island. It is not clear how this limitation could be overcome with the equinment specified in the study. Therefore, Cases 2 and 4 were not considered for this assessment. 


\subsection{ADDITIONS TO GENERAL SITE CRITERIA FOR GREENFIELD ASSESSMENT}

A Greenfield industrial facility would need to consider many items regarding site selection and site development. Some of the primary site selection items for an electric generating facility are:

- Availability of resources (e.g., coal, limestone, water)

- Disposal of wastes (e.g., ash, wastewater)

- Environmental considerations (e.g., emissions, noise)

- Proximity to electrical transmission facilities

The original Plant Wansley study utilized as much of the existing Plant Wansley facilities as possible; however, considerations for the potential siting of future pulverized coal fired plants at Plant Wansley limited those items that could be shared as common facilities with the IGCC plant. Overall, the IGCC facility designed for the Plant Wansley site was largely a standalone farility utilizing only the following existing items:

- Land and the cost of land acquisition

- Coal unloading and coal storage facilities

- Roads and railroad facilities

- General offices and administration Ash disposal facilities

For the Greenfield assessment, the addition of the above mentioned items to the overall cost estimate was necessary to convert the original study to a Greenfield assessment. In addition, a redesign of the coal and limestone handling facilities was required since the original coal and limestone handling facilities were designed specifically to fit within the existing coal handling scheme at Plant Wansley. This section discusses each of the modifications and additions to the original Plant Wansley study that were necessary for the Greenfield site conversion. Figures 3-1, 3-2, and 3-3 show the overall IGCC plant general arrangement, based on the new Greenfield site design for cases 1,3 , and 6 , respectively.

\subsection{GREENFIELD SITING ASSUMPTIONS}

The location of the Greenfield site for the IGCC unit was assumed to be a centrally located site within the boundaries of the Southern electric system. The site was assumed to be within close proximity to the Southern electric system electrical distribution system and within close proximity to existing major roads and railways. The prevalent terrain was assumed to be slightly rolling. 
Coal and limestone delivery would be accomplished by rail, and disposai of ash would be accor.splished by trucking accumulated ash to an onsite dry ash landfill.

\subsection{SITE PREPARATION KEQUIREMENTS AND LAND COSTS}

Although some costs associated with site preparation were included in the original Wansley study, a significantly larger amount of site preparation was required for development of the Greenfield site. These items included the cost of land, the cost of land acquisition, clearing and grubbing of the land, site grading and leveling, and compacting the soil for foundation preparation. For the Greenfield site these costs were estimated, using the basis of a gently rolling landscape with an approximate elevation change of 10 feet per 1000 feet. Each of these site preparation costs could vary significantly depending on the specific location of the site, the associated terrain, proximity to population centers, proximity to industrial facilities, etc.

For the Greenfield site, the cost of land was assumed to be approximately $\$ 1500$ per acre, with an additional land acquisition cost of $\$ 1500$ included. This cost is based on the average cost of land for rural southeastern undeveloped areas. The amount of land required for the IGCC facility was determined based on providing a buffer of approximately 1200 feet between the operating facility and any adjoining neighbor:s that could be potentially inpacted from a noise or environmental aspect of operation.

A variety of factors could dictate significant changes to the quantity of land required. Decisions regarding ash use or disposal, quantities of coal and limestone storage, potential integration with industrial facilities for cogeneration applications, proximity to required resources, and other major siting factors could greatly affect the amount and the cost of land required for the facility. It should therefore be noted, that the land requirement utilized within this economic evaluation is not technology dependent, but is site and management specific. In the original assessment, no land costs were considered because the acreage needed for the facility and the associated landfill were already owned by Georgia Power Company.

Due to similarities in the basic footprint of the IGCC unit for cases 1, 3, and 6 the total additional site preparation costs are virtually the same for each of the cases. Case 1 and 6 are exactly the same and case 3 is approximately 95 percent of the cost of case 1 . 


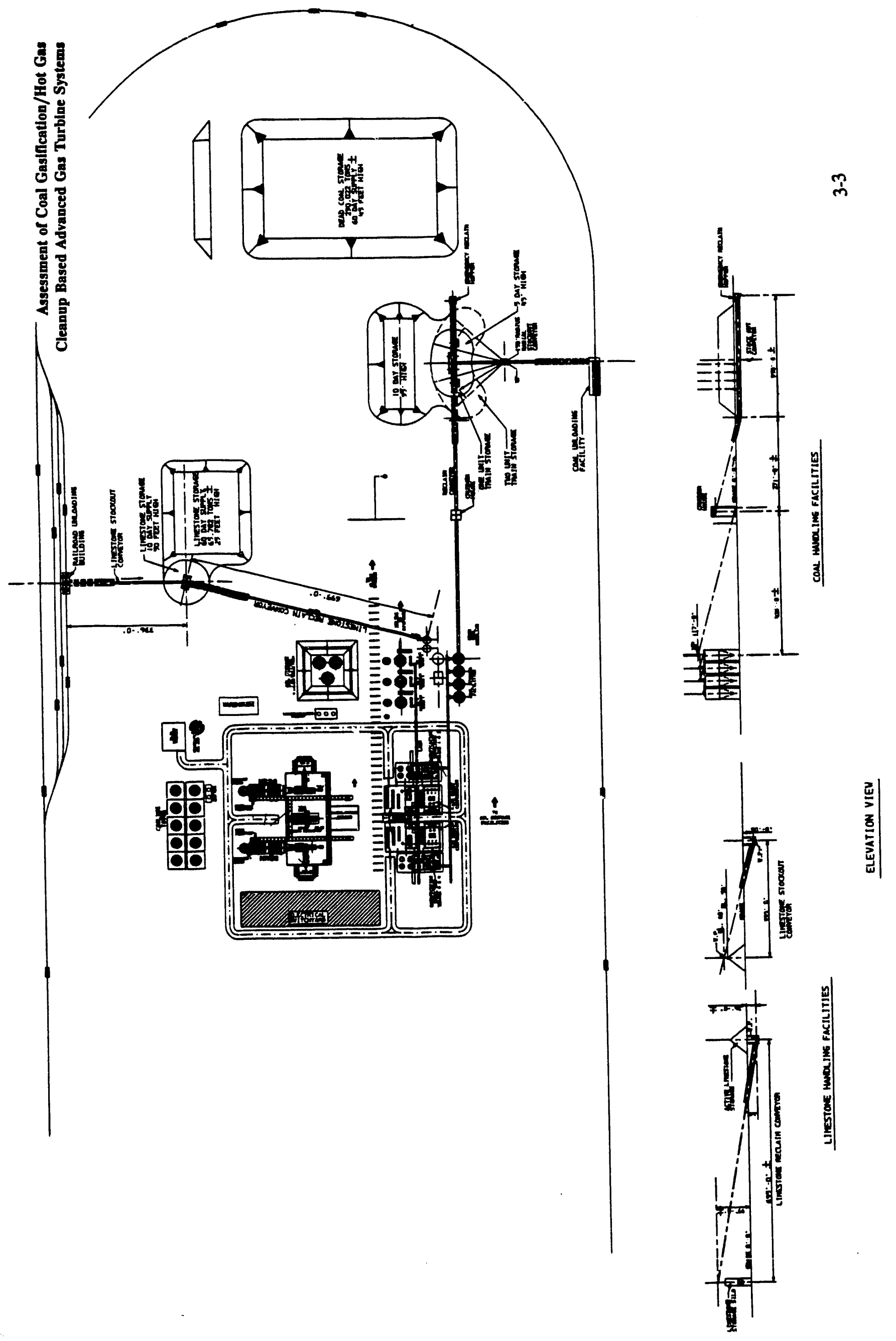




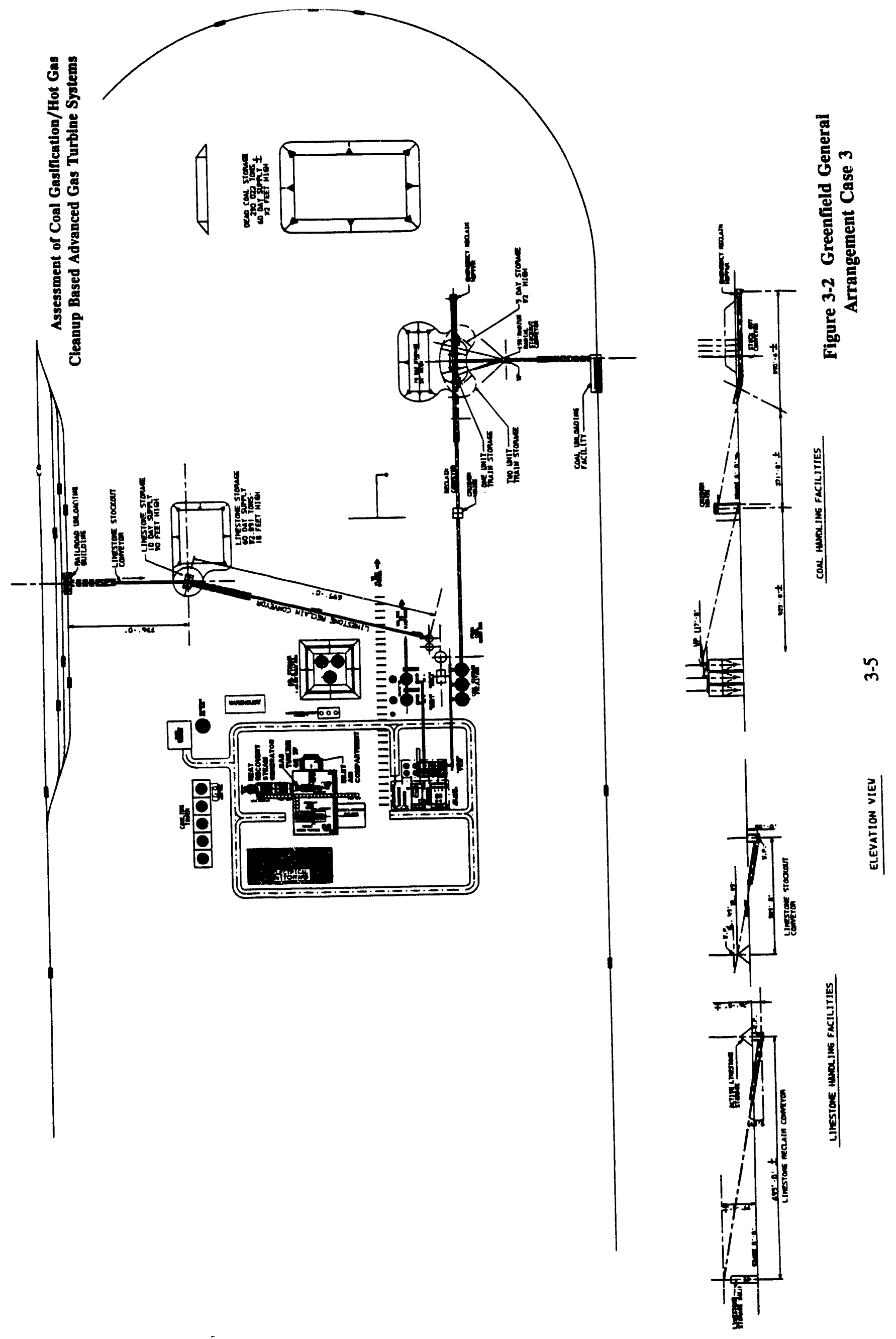




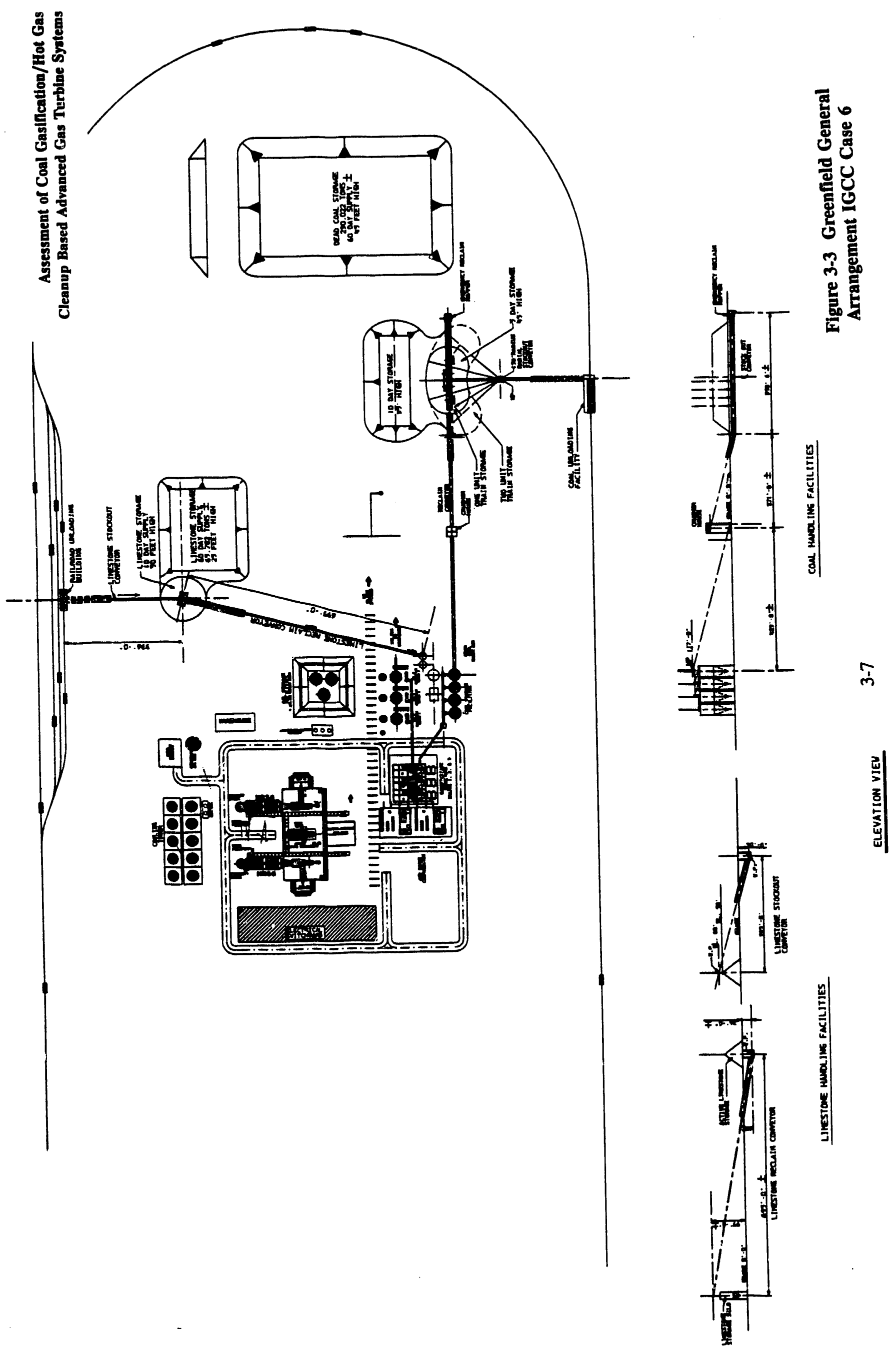




\subsection{WATER SUPPLY COSTS}

For the most part, the original Plant Wansley IGCC study included facilities and equipment to provide the necessary water supply to the IGCC plant. This included a water intake structure at the river, makeup water supply piping, and pumps to supply the water for plant makeup and cooling. A potable water supply and distribution system was added to the Greenfield site design.

\subsection{COAL HANDLING REQUIREMENTS}

For the Greenfield assessment, a railroad loop was added to the facility as well as a coal receiving structure, coal crushing equipment, a 60-day coal storage facility, and a fuel spreader known as a radial stacker. This section discusses the design criteria for the new facilities added to the IGCC designs, for Cases 1, 3 and 6 , to build a Greenfield plant.

\subsubsection{Coal Handling Specifications}

It was assumed that coal (sized 3 in. $x 0$ ) would be delivered by 100 -car unit trains, with bottom dump cars. For Cases 1 and 6, the unit trains would arrive at the plant site every 2 to 3 days, for Case 3 , delivery would be less frequent. The material handling system was sized the same for all three cases because the facility had to be capable of unloading the unit train in 4 hours. The first two cars of the unit train would be positioned over the two-car track hopper. The unloading of the bottom dump cars would be assisted by two heavy duty car shakers. Once these cars are emptied, the unit train will index and position two new cars over the unloading hopper. This sequence will continue until the train is empty.

The discharge of the hopper will have four slide gates and four belt feeders. The coal from the four belt feeders will transfer to collecting conveyor \#1. The material is then passed to conveyor \#2, which discharges onto the radial stacker to conveyor \#3. The radial stacker will have a capacity of two train loads and the unloading rate needs to be 2800 tph for all cases.

The dead storage pile was sized for 60 days, based on design operating conditions. It should be noted that the DOE cost of electricity model includes 60 days of fuel supply in the cost model. Therefore, the only additional cost to the original report for the Greenfield assessment will be the capital costs associated with the dead storage pile. The reclaim system was designed as a single line conveyor system to the coal silos. Conveyor \#4 has four vibrating pile dischargers with four belt feeders that will reclaim coal from under the live storage pile. Conveyor \#4 can also be fed from the emergency reclaim hopper located at the end of the conveyor. Conveyor \#4 also has a self cleaning magnetic separator at the discharge chute which leads into the crusher surge bin. A belt feeder transfers 
the coal into the coal crusher to reduce the coal to $1-1 / 4$ in. $\times 0$. The coal from the crusher discharges to conveyor \#5 which will discharge onto the cascade conveyor \#6. Conveyor \#6 distributes the coal into four storage silos. For Cases 1 and 6 the reclaim system should have a capacity of 1050 tph and shall operate two shifts per day.

The coal will be fed from the silos into four pulverizers. Three milling trains operate continuously, one mill as a backup unit. Hot gases from the sulfator will be used for drying the crushed coal. An oil-fired air heater was assumed for startup. The coal from the operating pulverizers will be transported to a common coal/limestone bunker.

\subsubsection{Limestone Receiving, Storage, and Handling}

The limestone handling system was not changed significantly from the December 1990 report. Crushed limestone will be received by train and unloaded on a spur. The rail car system will consist of a covered single car receiving hopper with a car shaker and two belt feeders. The belt feeders discharge onto conveyor L1, which forms a 50-foot high pile adjacent to the 60-day limestone storage pile. A dust suppression system will be used at the receiving hopper and the stockout conveyor.

The limestone reclaim system will have two reclaim hoppers located under the live storage pile. At the bottom of each hopper is a slide gate and belt feeder. The belt feeders discharge onto conveyor L2, which transports the limestone to two storage silos.

The limestone is fed from the silos into two pulverizers to be milled and dried with an oil fired heater. The limestone mills operate two shifts per day, with the third shift for maintenance. The pulverized limestone from the mills is collected in a 24-hour milled limestone silo. Two 100-percent capacity pneumatic conveying systems transport the limestone to the coal/limestone bunker.

The coal and limestone are fed separately with weigh feeders from the coal/limestone bunker into the transport tanks. Four pneumatic conveying systems transport the coal and limestone mixture to the four gasifier surge bins. Each weighing and pneumatic system will be capable of filling any gasifier surge bin.

\subsection{TRANSPORTATION, ROAD AND RAILWAY FACILITIES}

The original Plant Wansley IGCC unit utilized as much of the existing roads and railways as possible. A large savings was realized in the original study by utilizing the existing railways, with only the addition of some spurs required. The Greenfield assessment added the costs for a complete railway loop for coal and 
limestone delivery. This amounts to approximately 12,000 linear feet of railway for each of the three cases.

Roadways for the original Plant Wansley study were integrated into the existing roadways at Plant Wansley. The original study included most roads required for personnel access to all equipment but did not include a plant access road. A 2-mile plant access road has been added to the Greenfield facility to account for this requirement.

\subsection{ASH DISPOSAL FACILITIES}

In the original December 1990 report, a separate ash disposal landfill was designed for the IGCC facility, primarily because the existing ash handling system at Plant Wansley was a wet sluice and insufficient capacity and environmental concerns would not allow for use of the existing facility. A determination was made that the ash generated by the IGCC plant would be a dry ash and would be better managed with a dry landfill. The technology for ash disposal did not change for the Greenfield assessment, as a separate dry ash landfill was also utilized.

For the Greenfield site, the same dry ash landfill design is utilized, however a more detailed cost estimate of this facility was developed during the study and the costs for the Greenfield site have been updated to reflect this change. The landfill costs for Cases 1 and 6 are the same, with the overall landfill cost for Case 3 being approximately 58 percent of the Case 1 cost due to the lower quantity of ash production.

\subsection{ADDITIONAL MISCELLANEOUS COSTS}

Additional miscellaneous costs added for the Greenfield site development included:

- Office and shop space

- Security facilities

- Potable water supply

- Transmission access

In the original study, each of these items was previously accounted for to some degree within the existing Plant Wansley facility. Additional shop and office space of 10,000 square feet was added to assure that adequate space would be available to perform administrative and maintenance activities at the standalone facility. Perimeter fencing and a guardhouse were added to provide for the proper security facilities. A potable water supply and distribution system was added to provide for site potable water needs. 
The Greenfield study uses the same electrical distribution system as the original Plant Wansley study, which was based on a substation design that stepped up the power generation voltage to $500 \mathrm{kV}$ for transmission on a $500-\mathrm{kV}$ transmission line. For the Greenfield site the assumption is made that the facility will be located within 500 feet of an existing $500-\mathrm{kV}$ transmission line. A substantial cost increase could be realized if siting was a significant distance from existing electrical distribution system. A generic cost of $\$ 1,500,000$ per mile of required transmission line could be applied to the overall Greenfield site cost if desired. Additional cost changes would be realized if a lower voltage was required, such as $230 \mathrm{kV}, 115 \mathrm{kV}$. 


\subsection{ENVIRONMENTAL HEALTH AND SAFETY AND SOCIOECONOMIC ASSESSMENT}

Siting and permitting a Greenfield industrial site is much different from adding or replacing industrial facilities at an existing site. Local citizens, environmental groups, and even nearby Federal land managers have the right to intervene in the environmental permitting process. Public hearings and reviews of the industrial project are required for permits for each air emissions source, such as waste water discharge, solid waste disposal.

Permits for a new air emissions source can be time consuming because onsite data concerning ambient air quality and meteorological conditions are usually not available. Typically, ambient air monitoring is required for at least one year for permit modeling. New Source Performance Standards (NSPS) do not exist for IGCC at this time, and therefore baseline air emission limits have not been established, and this adds even more uncertainty to the permitting process.

The three IGCC plants considered in this study were designed to efficiently reduce all air emissions and effluents to regulatory limits or below, and to produce a solid waste suitable for landfilling. This section discusses the environmental impacts of the Greenfield IGCC facility, along with the safety and health impacts, and the socioeconomic impacts of construction.

\subsection{ENVIRONMENTAL PERMITTING PROCESS AND COMPLIANCE PLAN}

The environmental permit applications for constructing the plant will be submitted 2 years prior to the start of construction of the plant. Environmental permits will be required for air emissions, water discharge, and solid waste disposal. Each of these items is discussed in further detail in the following sections, along with the key design features, to ensure environmental compliance for the plant.

\subsubsection{Air Emissions}

Air emissions are primarily from five sources: coal storage and handling, limestone storage and handling, fines lockhopper vent gas, flue gas from the HRSGs, and flue gas from the sulfator. The lockhopper vent gas contains particulate from the fines-removal lockhopper. The flue gas from the HRSG contains $\mathrm{SO}_{2}$ and $\mathrm{NO}_{x}$ particulate and $\mathrm{CO}$. The hot particulate removal step removes virtually all the particulate from the gas stream that goes to the HRSG. The flue gas from the sulfator contains $\mathrm{SO}_{2}, \mathrm{SO}_{3}, \mathrm{NO}_{\mathrm{x}}$, and particulate produced during the oxidation of the sulfides and unburned carbon in the spent limestone containing ash (LASH). 


\subsubsection{Emissions Control}

\section{Vent Gas}

The vent gas from the fines removal lockhopper is filtered in order to meet particulate emission standards prior to being flared. Carbon monoxide in trace amounts is the only pollutant that remains in this gas after flaring. However, the volumetric flow of the vent gas is expected to be very small. With the small flow and low concentration of carbon monoxide, the ambient air quality standard concentrations will be below National Ambient Air Quality Standards (NAAQS):

\section{HRSG and Sulfator Flue Gas}

$\mathrm{SO}_{2}$ emissions are controlled by in-bed desulfurization in the gasifier and by removal of most of the remaining sulfur by a zinc ferrite sorbent. Sulfur removal efficiencies greater than 99 percent are achieved in all three cases for the fuel gas supplied to the combustion turbine.

Pilot plant measurements by M.W. Kellogg (MWK) have indicated that $\mathrm{NH}_{3}$ in the fuel gas results in $\mathrm{NO}_{\mathrm{x}}$ emissions ranging from 0.05 to 0.2 pound $\mathrm{NO}_{\mathrm{x}}$ per MMBtu when limestone is used for in-bed desulfurization and up to 0.6 pound $\mathrm{NO}_{x}$ per MMBtu without limestone.

Efficient particulate removal is achieved in the fuel gas by a cyclone and a ceramic candle gas filter. Pilot plant data from MWK indicate that particulate concentrations in the fuel gas are well below $10 \mathrm{ppm}$.

$\mathrm{SO}_{2}$ and $\mathrm{NO}_{\mathrm{x}}$ emissions from the sulfator are controlled by limiting the temperature in the sulfator. Sulfur released from the char in the sulfator reacts with the limestone and is converted to calcium sulfate. In Cases 1 and 3 the sulfator flue gas is used for coal drying, then filtered to meet particulate emission standards prior to release.

\subsubsection{Modeling}

In the site specific study, the Industrial Source Complex Short Term (ISCST) model was used to estimate the impact of the gasification-based power plant on air quality for all cases. The maximum 1-hour concentrations for $\mathrm{SO}_{2}, \mathrm{NO}_{\mathrm{x}}$, and particulate emissions were estimated. Then 3-hour and 24-hour concentrations were determined by factoring the 1-hour concentrations as recommended by the U.S. Environmental Protection Agency (EPA).

Initially, the model was run with "worst case" meteorological conditions to estimate the maximum 1-hour concentrations for $\mathrm{SO}_{2}, \mathrm{NO}_{\mathbf{x}}$, and particulate matter below 10 micrometers in size (PM10) for Cases 1 and 6. For the case without a separate discharge point for sulfator flue gas (Case 6), the model indicates that 
short-term impacts are below the ambient standards for $\mathrm{SO}_{2}, \mathrm{NO}_{\mathrm{x}}$, and particulate. For Case 1, the model indicates that short-term impacts of $\mathrm{NO}_{\mathrm{x}}$ and particulate are less than the Prevention of Significant Deterioration (PSD) significant impact levels. The $\mathrm{SO}_{2}$ impact exceeds the trigger level for preconstruction ambient monitoring. The concentration of $\mathrm{SO}_{2}$ for Case 1 is due primarily to the emissions from the sulfator. In Cases 1 and 3 the sulfator flue gas is released from a separate stack and the volumetric flow rate from this stack is much less than the flow from the stacks at the HRSG. The plume from the sulfator stack cools rapidly due to the small flow. The rapid cooling results in a relatively small plume rise and consequently results in less dispersion of the gas.

Because of the impacts calculated for Case 1, the model was run for all cases using meteorological data from the region near Plant Wansley instead of the "worst case" data. The impacts predicted by the model for $\mathrm{SO}_{2}, \mathrm{NO}_{x}$, and PM10 are listed in Table 4-1 for Cases 1, 3, and 6. The impacts for $\mathrm{NO}_{\mathrm{x}}$ and particulate are below the monitoring trigger level for all cases. The monitoring trigger level for $\mathrm{SO}_{2}$ was exceeded in Cases 1 and 3, but only slightly. Under PSD regulations, exceeding the monitoring significant impact level may require preconstruction $\mathrm{SO}_{2}$ monitoring for a period of up to one year at the plant site. This monitoring serves to determine the existing air quality and meteorological conditions at the plant site. Although the monitoring trigger level for $\mathrm{SO}_{2}$ may be exceeded, the actual concentration of $\mathrm{SO}_{2}$ should be far below the NAAQS.

Table 4-1

ISCST Model Predicted Impacts of IGCC Plants on Air Quality

$\begin{array}{lrrrrr} & \underline{3 \mathrm{hr}} & \begin{array}{r}\mathrm{SO}_{2} \\ \underline{24 \mathrm{hr}}\end{array} & \underline{\underline{\text { Annual }}} & \begin{array}{r}\mathrm{PM}-10 \\ \underline{24 \mathrm{hr}}\end{array} & \begin{array}{r}\mathrm{NO}_{\mathrm{x}} \\ \text { Annual }\end{array} \\ \text { Case 1 Impact } & 85 & 23 & 3.0 & 0.1 & 3.0 \\ \text { Case 3 Impact } & 56.7 & 16 & 2.1 & 0.4 & 1.2 \\ \text { Case 6 Impact } & 39.3 & 10.4 & 1.2 & 0.5 & 0.6 \\ \text { Monitoring Sig.b } & & & & & \\ \text { Impact Level } & -- & 13 & - & 10 & 14 \\ \text { PSD Increments } & 512 & 91 & 20 & 30 & 25 \\ \text { NAAQS } & 1,300 & 365 & 80 & 150 & 100\end{array}$

Concentrations in micrograms/cubic meter

Predicted impacts are "highest-second-high" for 3- and 24-hour averaging times. 
Since the $\mathrm{SO}_{2}$ monitoring level is exceeded due to the small flow from the separate stack, rearranging the plant or making other design changes to allow the sulfator gas to share a common stack with the flue gas from the HRSG may be recommended. Modeling indicates that the significance level would not be exceeded if a common stack was used.

\subsubsection{Minor Constituents}

Environmental test programs were carried out in the KRW pilot plant to determine the fate of the minor constituents in the coal and limestone feed such as alkali and heavy metals, halides, and hydrocarbons. Some of these minor constituents, such as alkali metals and halides in the fuel gas, can be tolerated by the gas turbine at only very low levels. A significant amount of analytical work related to the fate of these minor constituents was completed. The Radian Corporation performed two environmental sampling series of studies at the pilot plant. A 1983 testing study involved oxygen-blown gasifier operation with Pittsburgh No. 8, Wyoming, and North Dakota lignite coals (3). The second testing study was performed during a 1988 proprietary test series involving airblown gasifier operation with and without in-bed desulfurization. Because the gasifier conditions do not vary significantly between the operating modes and the bituminous feedstocks, it is reasonable to draw general conclusions about the minor constituents applicable to this study.

The minor constituents, chloride, alkali metals, trace elements such as calcium and vanadium, volatile organics, and high molecular weight organics were studied in the 1988 testing series and are reported in the December 1990 report. To permit a Greenfield facility, the amount of air toxics emitted per year would need to also be estimated.

\subsubsection{Waste Solids Disposal}

The solid wastes, including spent limestone, ash, spent zinc ferrite sorbent, and nahcolite sorbent, are disposed of in a dry landfill at the plant site. All of these wastes are nonhazardous using the EP toxicity test. Various leaching studies of solid wastes from the KRW gasifier at Waltz Mill, Pennsylvania, were conducted using materials produced in the pilot plant with and without in-bed desulfurization. Also, samples of LASH material from the pilot plant in-bed desulfurization tests, both before and after sulfation treatment were tested. In every case the EP-toxicity test results of LASH showed compliance with the requirements of the Resource Conservation and Recovery Act (RCRA) of 1976. The LASH material has not ben tested using the new Toxicity Characteristic Leachate Procedure (TCLP). Sulfation tests were conducted for MWK by DorrOliver to determine the extent to which sulfides in the LASH could be converted to sulfate. Results of the Dorr-Oliver tests were reported in the December 1990 report. 
The original landfill for the gasification facilities' solids disposal was lined with a 3 -ft thick clay liner, and all leachate and surface runoff from the landfill were routed to a sedimentation pond (also lined with clay) for removal of entrained solids prior to discharge at an existing water discharge point. For the Greenfield assessment, a synthetic liner was added to the landfill design. Although the liner may not be specifically required, since the waste materials are not RCRA hazardous waste, Greenfield siting may be much easier if the community understands that the landfill is double lined. A leachate collection system is still included in the cost of the landfill.

Four groundwater monitoring, wells are located around the landfill. When ash is stacked to the maximum design height for the landfill, the material will be covered with a 2-ft layer of soil, and grass will be planted. Figure 4-1 shows the location of the landfill for Case 1.

\subsubsection{Water Consumption Permits}

A Consumptive Use Permit and/or a Water Withdrawal Permit may be required if the need for ground or surface water meets the thresholds outlined in state regulations. Most likely, all of the three cases discussed in this report would fall within these thresholds and thus be required to obtain a Water Consumption Permit and or a Water Withdrawal Permit. To obtain these permits where groundwater is withdrawn, potential impacts of groundwater usage cn surrounding permitted wells will need to be addressed. This analysis often requires groundwater modeling.

\subsubsection{Water Discharge Permitting}

Water discharge to a surface water is regulated by EPA or state agencies through a National Pollutant Discharge Elimination System (NPDES) Permit. Effluent limitations in the permit would probably be established pursuant to the Steam Electric Effluent Guidelines (40 CFR 423) or Best Engineering Judgement, depending on the process similarities with familiar steam generating facilities. State administered surface water discharge permits and Federal NPDES permits may be issued only if the expected discharges are determined to result in no violation of water quality standards. The water quality damage determination depends on the classification of the receiving stream (the stream flow) and may require surface water modeling. Stormwater discharges would also be permitted through the NPDES program.

The waste water from the KRW IGCC design differs considerably from the waste water typically associated with coal gasification facilities. Typical IGCC plant designs include many different water streams leaving the facility that have had direci contact with the coal, ash, char, or process gas streams which would have high levels of contaminants. However, the MWK gasifier design does not include 
a coal slurry feed system or an ash slag quenching section. In addition, because of the limestone in-bed sulfur recovery system, there is no Rectisol, Selexol, Claus, or Stretford system to generate a waste water stream.

Most of the water streams to be discharged from the gasification-based plant are the same as streams in conventional power plants, such as boiler blowdown, cooling tower blowdown, stormwater. In this study, water streams are treated by conventional techniques for coal pile runoff and structure runoff. Runoff from the limestone storage area, combined with the coal pile, run off to a small settling basin, which will allow sufficient time for solids to settle prior to discharge.

In all cases, leachate and surface runoff are collected from the ash landfill and routed to a sedimentation pond. The sedimentation pond and existing sedimentation ponds at the site have sufficient capacity to contain the 24-hour, 10-year rainfall runoff from the landfill. This scheme allows all solids to settle prior to discharge at an existing point. No further treatment is anticipated, but by collecting the water, additional treatment, such as $\mathrm{pH}$ adjustment, would be possible if it became necessary.

\subsubsection{Miscellaneous Permitting}

Depending on the location of the IGCC site, environmental permitting of the facility will be subject to a number of state or local requirements. Some states have authority to administer their own water and/or air programs that may have additional restrictions and permitting requirements. In addition, some states have other siting regulations for industrial facilities. For example, Florida has a Power Plant Citing Act that must be followed for Greenfield facilities over $25 \mathrm{MW}$.

\subsection{OTHER PERMITTING ISSUES}

Other permitting issues or important tasks for a Greenfield project in the environmental permitting process include an Environmental Impact Study (EIS) or Environmental Assessment (EA), an endangered species study, a noise survey, a wetlands evaluation, and an archaeological survey. Each of these are discussed in this section.

\subsubsection{Environmental Impact Study}

An EIS, or an EA, would be required to site a Greenfield IGCC facility. This document will include site specific information about major and minor impacts of an industrial facility on the surrounding area. Information about wetlands on the site, potential endangered species in the area, and potential for archeological discovery to be found are included in this document. Typically the EIS or EA is placed on public review for comments before any governmental permits are issued. 


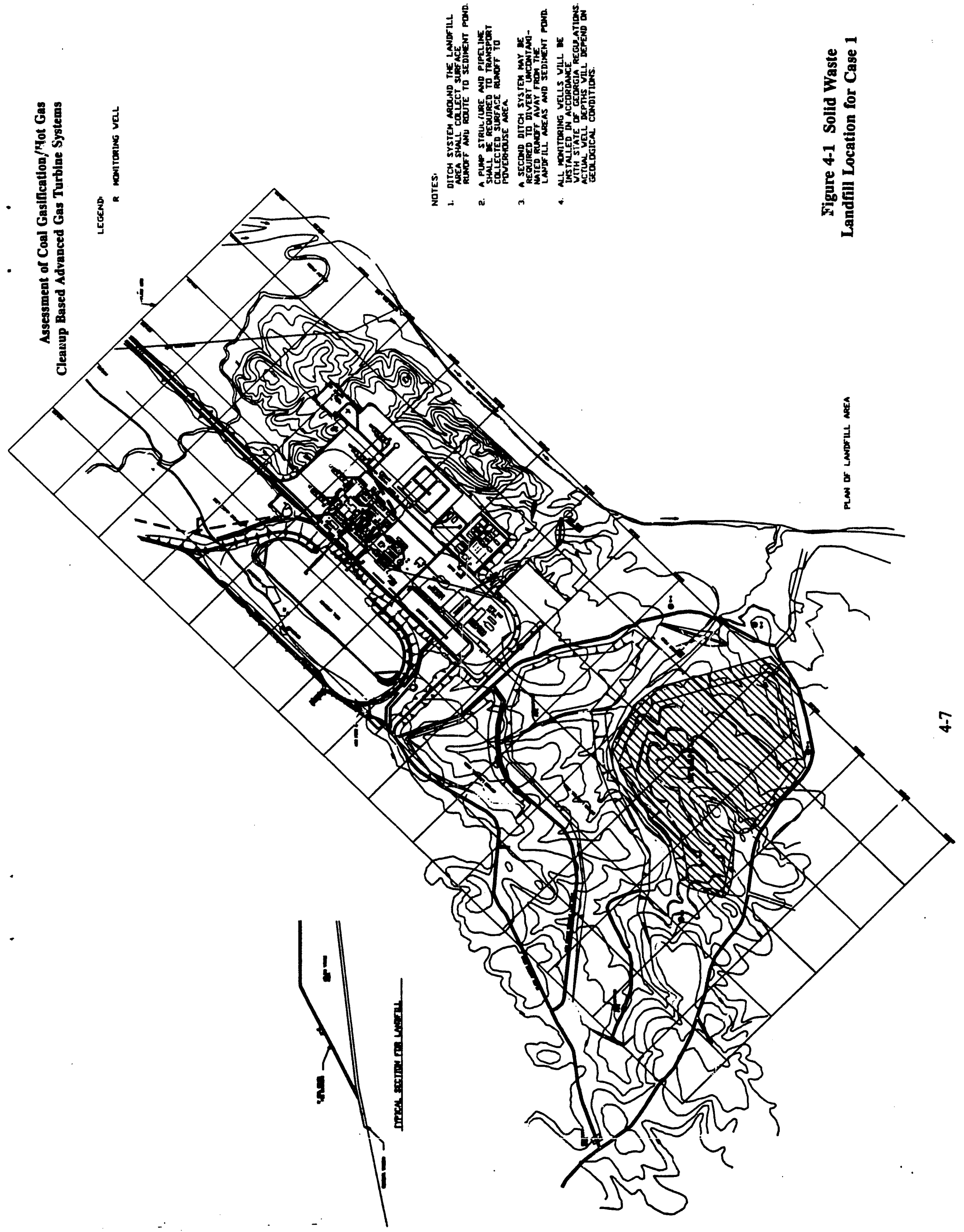




\subsubsection{Endangered Species}

Listed, threatened, and endangered species will need to be identified for the area chosen as the site for an IGCC facility. Typically, lists of endangered species can be obtained from the United States Fish and Wildlife Service. Appropriate mitigative and protective measures may need to be taken to ensure minimal impacts on endangered species.

\subsubsection{Noise Survey}

A noise survey for the facility should be conducted to ensure that any local ordinances concerning noise can be met at the property boundary. In this cost assessment, a 1000 - $\mathrm{ft}$ boundary was assumed around the IGCC facility to ensure that any noise from the facility would have a minimal impact on the surrounding area.

\subsubsection{Wetlands Evaluation}

To site a Greenfield facility, care must be taken to minimize adverse effects on wetlands during construction and operation. Permitting agencies for wetlands include the United States Army Corps of Engineers, the EPA, and state and local soil and water conservation boards. Permits to disturb or impact wetlands are increasingly difficult to obtain and, therefore, all appropriate efforts to enhance or protect existing wetlands should be undertaken.

\subsubsection{Archaeological Survey}

Usually an archaeological survey is conducted as a part of the EIS or EA to ensure historic preservation.

\subsubsection{Health and Safety}

The health and safety requirements applicable to operation of the proposed gasification power plant include the construction and general industry standards of the federal Occupational Health and Safety Administration, as listed in 29 CFR, Parts 1910 and 1926, respectively. These standards include walking-working surfaces, means of ingress and egress, operation of powered equipment, adequate ventilation, noise exposure, fire protection, and electrical equipment safeguards. It is believed that current procedures are adequate to ensure that federal and state standards are met. 


\subsubsection{Socioeconomic Impacts}

The socioeconomic impacts of the IGCC facility may differ considerably depending on the site chosen. The socioeconomic impacts will be expressed differently during construction and operation. The labor pool geographical source for construction workers and plant operations personnel will normally be the local and nearby counties. The required workers are expected to be available from the local area and no adverse effects to area public services are anticipated. 


\subsection{CAPITAL AND OPERATING COST ESTIMATES}

\subsection{CAPITAL COST ESTIMATES}

Sections 1 and 2 and Appendix A describe plant designs for three IGCC power plants (Cases 1, 3, and 6). Based on these plant designs, conceptual capital cost estimates were developed using the standard methods, data sources, and costing philosophies employed by SCS and MWK. This section presents the capital cost results for these plant designs and includes costs for Greenfield siting and operation.

\subsubsection{Estimating Assumptions and Procedures}

Using information on design criteria, flow diagrams, equipment lists and specifications, material and energy balances, and equipment layouts reported in the December 1990 report, SCS and MWK prepared process area plant costs from which total capital requirement estimates were built. MWK developed the basis for the gasification costs, while SCS was responsible for the power island, materials handling, solids handling and disposal, and the general facilities. SCS used these costs to prepare the overall capital cost estimates for Greenfield IGCC plants. To remain consistent with the December 1990 report, all capital costs are expressed in mid-1990 dollars.

The total capital requirement is projected by estimating the following components:

Process plant cost

General facilities, engineering, contingencies

Total plant cost

AFUDC

Total plant investment

Royalties, initial inventory, startup, spare parts, working capital, and land (=owner's costs)

Total capital requirement
A
B
$\mathrm{C}=\mathrm{A}+\mathrm{B}$
$\mathrm{D}$
$\mathrm{E}=\mathrm{C}+\mathrm{D}$
F
$\mathrm{G}=\mathrm{E}+\mathrm{F}$

The cost of electricity was calculated in the same format as the December 1990 report. DOE supplied a cost-of-electricity model and format for calculation of costs developed in the study. The usual EPRI Technology Assessment Guide (TAG) format for presenting capital costs was adapted in minor ways to conform to the DOE cost model format, as will be pointed out subsequently.

The major cost items specified above are described in more detail in this section. 


\section{Process Plant Cost}

The process plant cost is the compilation of the individual process section costs. None of the process section costs were changed for the Greenfield assessment. Only plant support costs in the coal, limestone, and ash handling areas, as well as the general facilities area, were changed as a result of the Greenfield report. In the original report, both SCS and MWK employed engineers and professional cost estimators to develop these costs using the following sources: a) firm vendor quotes, b) budgetary vendor quotes, c) recent procurement of similar items, d) historical, in-house experience and data bases. Most of the Greenfield costs were derived from historical and recent procurement costs. The components of the process plant cost are direct field material costs, direct field labor and subcontract costs, indirect field material and labor costs, and costs of freight and sales tax.

The definition of direct field material costs did not change and are the costs of the permanent physical plant facilities which include the following:

- Equipment - includes all machinery, such as tanks, vessels, rotating machinery, boilers, and exchangers used in the completed facility.

- Material - includes the cost of all physical materials, such as cement, aggregate, sand, steel, building materials, pipe and fittings, valves, wire and conduit, instruments, insulation, and paint used in constructing the plant.

Direct field labor costs are unchanged and were determined by estimating field labor manhours and multiplying those manhours by wage rates. In some cases, direct labor costs were supplied by the vendors who provided quotes for specific major equipment pieces or subcontracts. The direct field labor wage rate was based on appropriate crafts applicable to the project type covered in this study and reflects a closed-shop project. As in the previous study, union rates appropriate for Georgia Power Company were used as a basis to determine the labor rate, which does not include indirect field costs such as benefits and burdens. It should be noted that the exact site location can influence field labor manhour estimates and wage rates; for assumption purposes, this study assumed the same location as Plant Wansley, but that no previous industrial operation existed. Therefore, field labor rates remained unchanged and cost estimates projected in this study may be substantially different from those for other locations.

Subcontract costs are the costs charged by a subcontractor for providing equipment or materials and installation. Included in these costs are the subcontractor's overheads and profits. In some instances, costs are represented in a lump-sum fashion and listed as subcontract items during the cost estimation. 
For the Greenfield assessment, in some cases additional costs were re-allocated to a subcontractor rather than a direct material cost.

Indirect field cost estimates were still based on construction experience with similar projects in The Southern Company and covered the following areas:

- The labor and material costs for temporary construction facilities, such as temporary buildings, roads, utilities, and railroads.

- The labor and material costs for construction services such as medical and first aid, janitorial work, final job cleanup, handling and servicing of construction equipment, and consumables (e.g., welding supplies).

- Contractor overhead and profit, which includes field staff and expenses.

- Field staff and craft burdens and benefits. Burdens include legally stipulated costs such as FICA, workmen's compensation, public liability and property damage, and state and federal unemployment insurance. Nonlegislated benefit costs include health, welfare, vacation, sick leave, holiday, travel expenses and mileage, pension fund, and apprentice fund.

- Construction equipment (purchased and rented) and small tools.

Freight charges were still included in the direct field material costs for the Greenfield assessment. Vendor-supplied freight costs were used when possible; otherwise, a 3-percent charge, based on total direct field material, was applied.

A sales tax rate of 4 percent was assumed in the previous report and is applied to the total direct equipment and material costs and to the material portion of the indirect costs and subcontract costs (where applicable). The sales taxes are included in the indirect field costs.

\section{Total Plant Cost}

The total plant cost (TPC) is the sum of the following:

- Process plant cost

- General plant facilities

- Engineering fees

- Process contingency

- Project contingency 
The major items constituting general plant facilities include plant and instrument air, buildings (such as the powerhouse and control room, warehouses, fire protection house, and service and cooling water houses), cooling water system, fire protection system, fuel oil storage and handling, gasification island support including the main flare system and fuel gas piping, intrasite communication systems, potable and utility water systems, road and rail facilities, sewer and effluent water treatment, site preparation and improvements, electrical switchyard and distribution, service water system, miscellaneous pipe racks, and instrumentation and controls. Since estimating the costs of general plant facilities fell completely within the scope of work for SCS for the original report, revising these numbers for the Greenfield assessment was also performed by SCS. As in the December 1990 report, the general facilities were actually treated as a process plant section for estimating purposes but were reported outside the process plant cost category to match the DOE cost-of-electricity format. In the DOE model, the default value for general facilities is 12.5 percent of the process plant cost. However, for the Greenfield assessment, the 1300 area actually totaled 11 to 15 percent of the TPC for the three cases.

The engineering fees covered the home office and outside contractor costs for engineering, design, and procurement for SCS and outside contractors such as MWK and GE. Also included are office and personnel expenses (e.g., computer costs, reproduction costs, and travel), licenser costs for basic process engineering, office burdens and benefits, wrapup and all-risk insurance, environmental permitting costs, and project management costs. These fees typically range from 7 to 15 percent of the process plant cost, and in the DOE model the default value is 11 percent of the process plant cost.

Two separate contingencies (i.e., a process contingency and a project contingency) are applied to the capital cost estimate. The process contingency is an effort to quantify the uncertainty in the design, performance, and cost of the commercialscale equipment. The different process contingency allowances applied to each major subsection of the plant in the original report remained unchanged.

\section{Total Plant Investment}

As in the original report, the total plant investment (TPI) is the sum of the TPC and the allowance for funds used during construction (AFUDC). AFUDC was the adjustment to the capital cost (based on TPC) to reflect the cost of using money over the period of construction. For comparison purposes, the AFUDC remained 10.83 percent compounded semi-annually. The AFUDC is also a function of the required construction schedule and the expenditure schedule during this period. The assumed construction period and expenditure schedule for the AFUDC calculations also remained unchanged as shown below: 


\begin{tabular}{lc} 
Cases & Case \\
$1 \& 6$ & $\underline{3}$ \\
\hline
\end{tabular}

Construction period, years

4.5

4.0

Expenditure schedule

Year 1

Year 2

Year 3

Year 4

Year 5
$5 \%$

$15 \%$

$30 \%$

$35 \%$

$15 \%$
$10 \%$

$20 \%$

$40 \%$

$30 \%$

$0 \%$

The estimated AFUDC is about 19.6 percent of the TPC for Cases 1 and 6 and about 19.1 percent of the TPC for Case 3.

Total Capital Requirement

The total capital requirement (TCR) was the sum of the TPI and the other remaining capital costs necessary to complete the entire project. These remaining capital items, which are often referred to as owner's costs, included the following:

- Prepaid royalties

- Initial catalyst and chemical inventory

- Startup costs

- Spare parts

- Working capital

- Land

Because vendor information on prepaid royalties was considered proprietary, the original report assumed a typical royalty of 0.5 percent of the process plant for all cases. The Greenfield assessment did not change this assumption.

The initial catalyst and chemical inventory covered the initial cost of any catalysts or chemicals contained in the process equipment. Because the majority of these costs in this study are for the gasification island, no changes were made in this category. 
Startup costs were intended to cover preproject administrative costs and operator training, equipment checkouts, changes in plant equipment, extra maintenance, and inefficient use of fuel and other naterials during plant startup.

Startup costs did not change for the Greenfield assessment. Similarly, spare parts inventory estimates stayed the same also.

The value of inventories of fuels, consumables, and byproducts was capitalized and included in the working capital account. As in the original report, the working capital cost included a 60-day supply of fuel and consumables and a 30day byproduct inventory.

Land costs were added to the costs for the Greenfield assessment. The DOE model assumed land costs to be $\$ 6500$ per square acre, with 435 acres needed for the Greenfield site. The land requirement increased for the Greenfield assessment because of the rail loop and a desire to have a noise barrier around the facility. The rail loop and noise barrier dictate the land requirement reguardless of plant size. A noise barrier should make siting the facility easier. In addition, a 40-year storage/disposal area for ash and fines is included at the site. In the event that ash disposal would be offsite, land requirements could be substantially reduced. In the previous report, no land costs were included because sufficient acreage existed at the Plant Wansley site.

\subsubsection{Capital Cost Results}

The capital cost results are presented in detail as the output from the DOE cost-of-electricity model in Appendix B for all Cases (1,3, and 6). The capital requirements are summarized in both millions of dollars and $\$ / \mathrm{kW}$ for the original report and the Greenfield assessment in Table 5-1. Because of the net output megawatt differences among the cases, most of the comparisons which follow are made with reference to the $\$ / \mathrm{kW}$ values. A more detailed breakdown of process plant costs by plant section is provided in Table 5-2. A breakdown of owner's costs is given in Table 5-3. 
Table 5-1

Capital Cost Summary

Mid-1990 Dollars

CAPITAL COST

Net power output, MW

Plant construction cost

Process contingency

Project contingency

Total plant cost

AFUDC

Total plant investment

Owner's costs

Total capital requirement
Case 1 $\$ \times 10^{6} \$ / \mathrm{kW}$

458.4

231.7

409.6

Case $3 \quad$ Case 6

$\$ \times 10^{6} \$ / \mathrm{kW} \quad \$ \times 10^{6} \$ / \mathrm{kW}$

$399.6 \quad 872$

$19.8 \quad 43$

$10.3 \quad 45$

$17.3 \quad 42$

$83.9 \quad 183$

49.1212

$73.5 \quad 179$

503.31098

294.71272

441.01077

93.7204

$52.4 \quad 226$

81.5199

596.91302

347.11498

522.51275

48.4106

28.8124

376.01623

Note: Plant construction cost $=$ Process plant cost plus general facilities and engineering fees. 


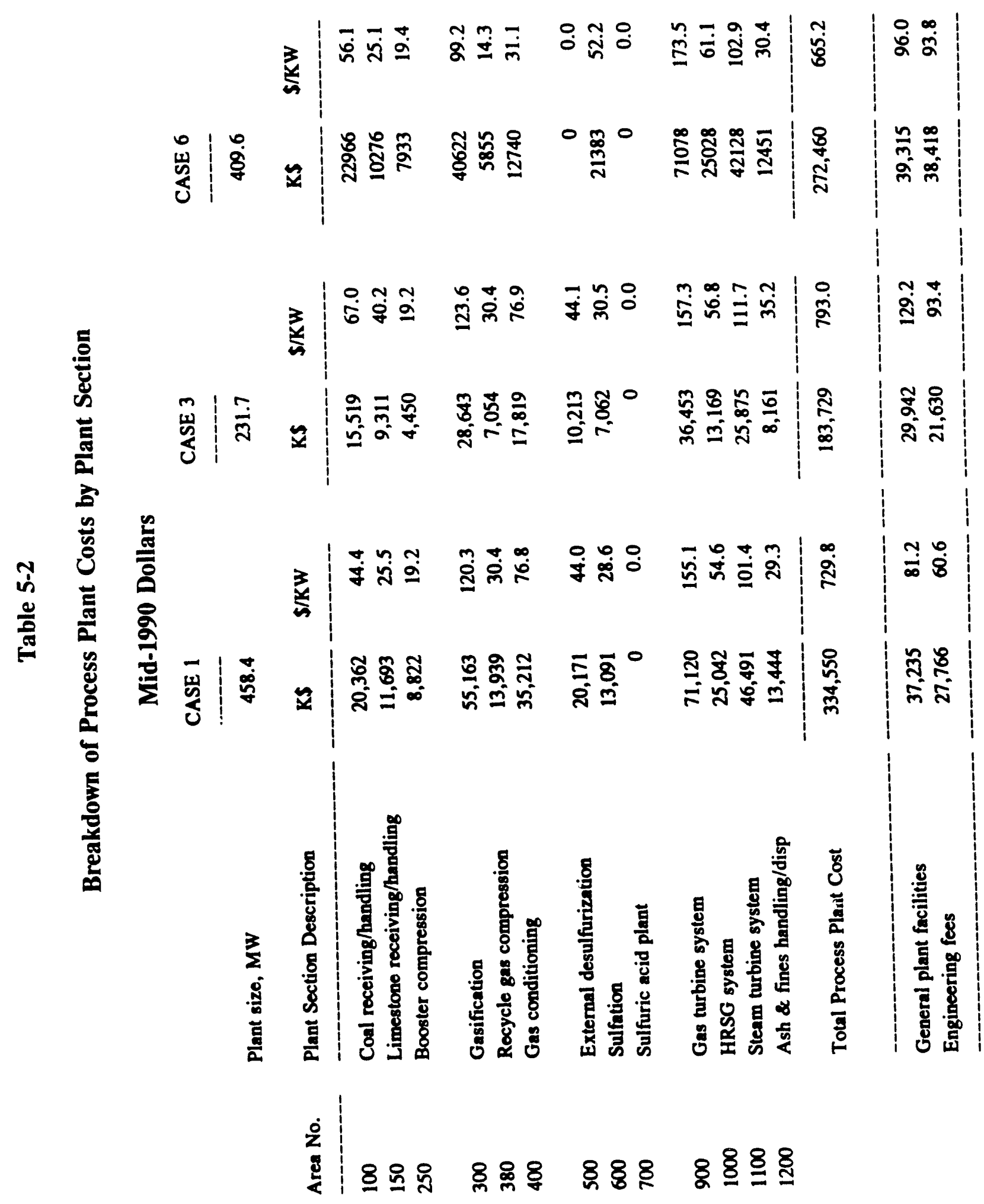




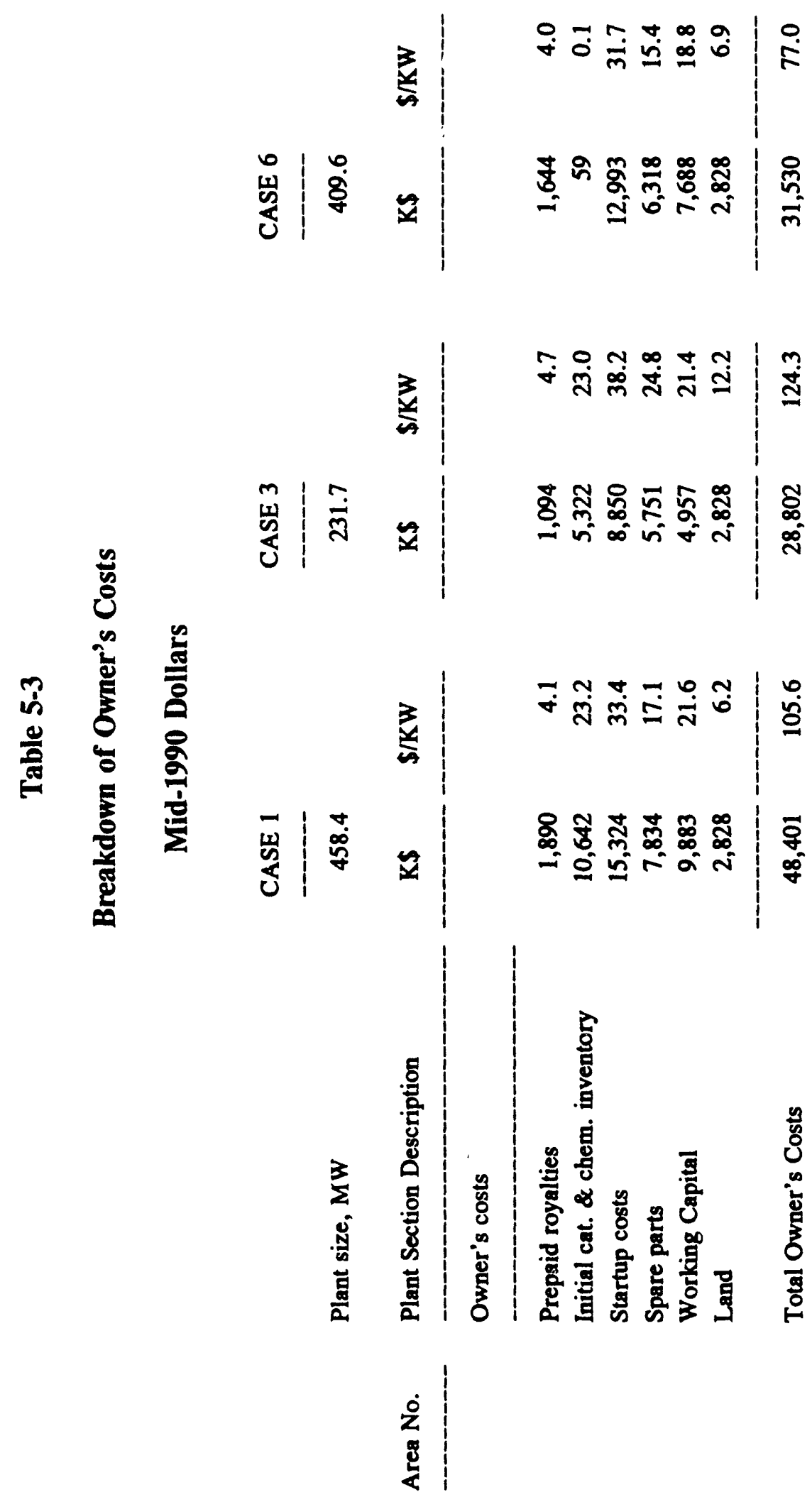


As in the original report, Case 6 possesses the lowest TCR of all the cases, and Case 1 is the second lowest TCR, due to economies of scale. This cost advantage for Case 6 is related to the rapid gasification and sulfur-capture reaction rates predicted for the transport reactor, leading to significant reductions of gasification island equipment and material costs. In the Greenfield assessment, the TCR is $1353 \$ / \mathrm{kW}$ for Case 6 and $1408 \$ / \mathrm{kW}$ for Case 1 . Compared to the original sitespecific study where Case 6 TCR was $1279 \$ / \mathrm{kW}$ and Case 1 TCR was 1342 $\$ / \mathrm{kW}$, the TCR increased an average of 5.83 percent.

Figure 5-1 is a bar chart displaying the TCR results for the three cases broken down into the following four components:

- Plant construction costs $=$ process plant cost + general facilities + engineering fees

- Contingencies $=$ process contingency + project contingency

- AFUDC

- Owner costs $=$ royalties + initial inventory + startup costs + spare parts working capital + land

As noted in Figure 5-1, the plant construction cost is still the major component of the TCR, representing about 60 percent of the TCR in each case. Also, variations in the plant construction costs account for the majority of the differences in the TCR results among the different cases. The contingency and AFUDC items are the next most costly components. These are about equal for the various cases, each representing approximately 15 to 17 percent of TCR owner's costs.

A breakdown of the process plant costs by major plant area groupings is given in Figure 5-2. Just as in the previous report, the single largest component in the process plant costs for all cases is the power island (composed of the gas turbine system, the HRSG system, and the steam turbine system). If the gasification and gas conditioning components are combined, the joint costs are slightly greater than the power island costs for most cases, except Case 6. Case 6 has much smaller gasification island requirements because of the high gasification and sulfur-capture efficiency predicted for the transport reactor. Most of the differences in the total process plant costs among the six cases results from variations in the materials handling, gasification, and gas conditioning costs, since power island equipment is virtually identical for similar size plants. 


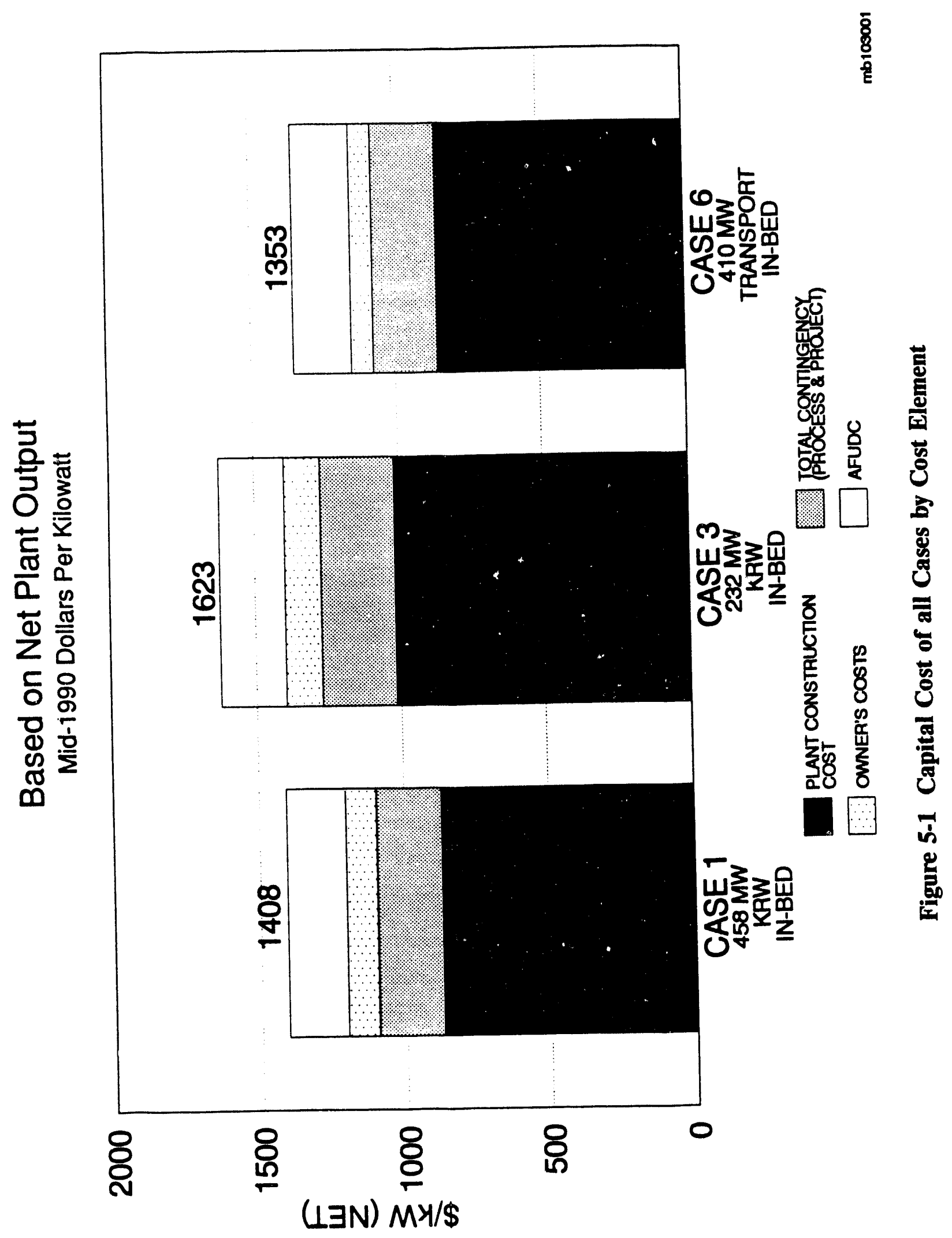




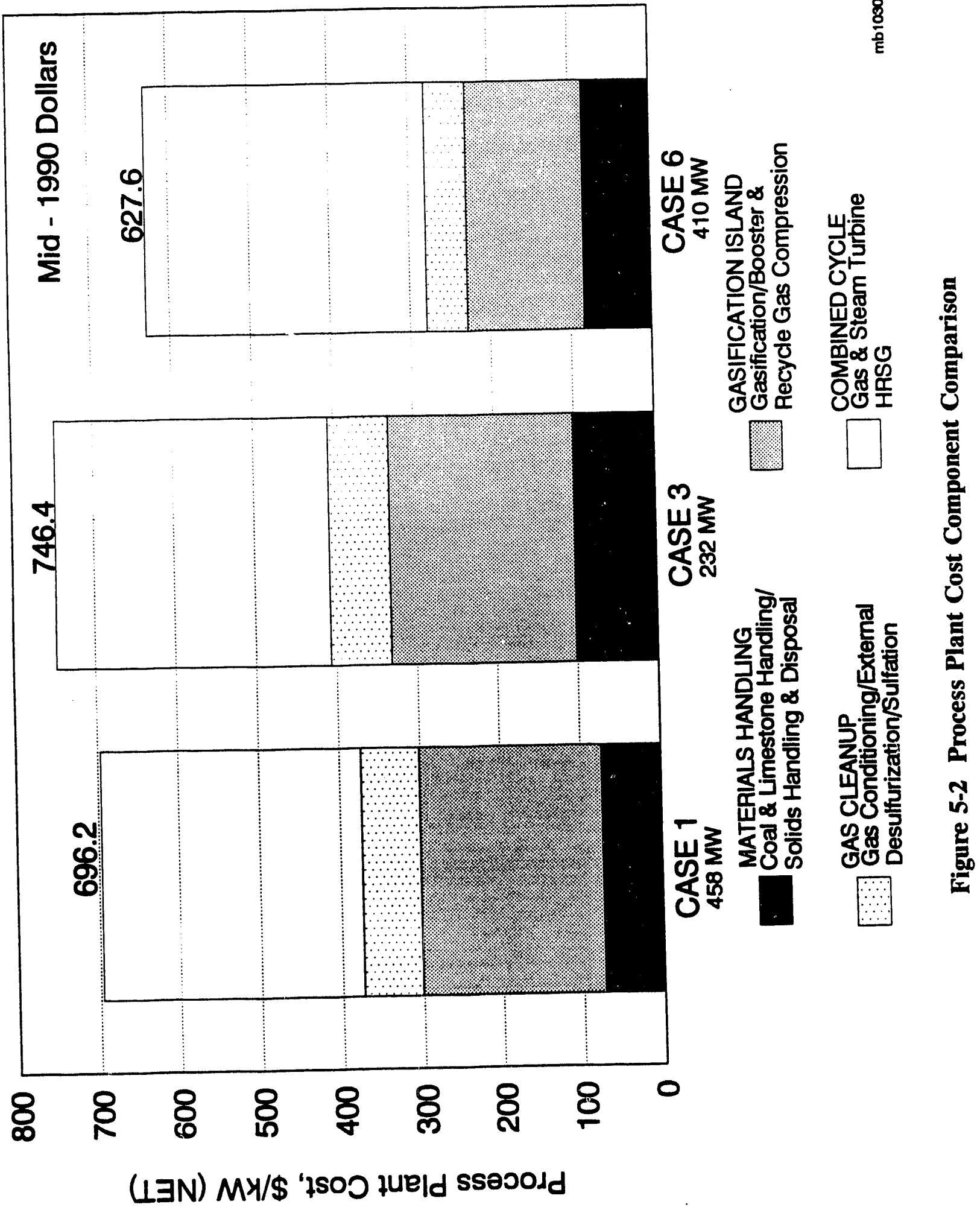




\subsection{OPERATING AND MAINTENANCE COST ESTIMATES}

\subsubsection{Estimating Assumptions and Procedures}

The assumptions for the O\&M costs for the Greenfield assessment remain the same as for the site-specific study. In the Greenfield assessment, both the coal handling and the limestone handling sections were redesigned. The additional manpower required for the coal handling section was estimated to be the same as the manpower reduction in the limestone handling section. However, because the original study utilized an average cost of raw materials, a cost savings was not recognized for rail delivery of limestone rather than truck delivery.

The O\&M costs are estimated for a year of normal operation at a 65 -percent capacity factor and are expressed in mid-1990 dollars. The 65-percent capacity factor was used because of the DOE requirement that costs of electricity be developed on this basis. The major unit costs for annual O\&M items are shown in Table 5-4. O\&M costs include fuel, variable O\&M, and fixed O\&M, which are described in the following paragraphs.

Table 5-4

Major Unit Costs for Annual O\&M Items

\section{Cost Item}

Fuel, Illinois No. 6 coal

Limestone

Nahcolite

Zinc ferrite

Solids disposal, Cases 1,3 , and 6

O\&M labor, wage rate (average including burden)
$\$ /$ Unit

$$
\begin{array}{r}
35.00 / \text { ton } \\
11.20 / \text { ton } \\
261.25 / \text { ton } \\
6,270.00 / \text { ton }
\end{array}
$$

$2.94 /$ ton

$21.80 / \mathrm{hr}$

The fuel type for all cases is unchanged and is Illinois No. 6 bituminous coal. The DOE cost model (Appendix B) calculates the annual fuel cost for each plant from the specified capacity factor, coal rate, and unit price. The delivered cost of coal was assumed to be unchanged for this stuf; , \$35/ton, based on the as-received coal costs for Georgia Power. 
The variable O\&M also did not change for the Greenfield assessment and is composed of consumable costs, ash/sorbent disposal costs, and byproduct credits. Byproduct credits, however, were applicable only to Case 5 which was not considered for this Greenfield study. Consumable costs cover the consumption of limestone, nahcolite, zinc ferrite, and other miscellaneous items. The annual costs for limestone, nahcolite, and zinc ferrite are calculated based on material balance data for each case. The miscellaneous items include the following:

- Fuel oil for startups

- Natural gas for operation of the emergency flare

- Cooling water treatment chemicals

- Service viater corrosion inhibitor

- Demineralization

- Nitrogen and hydrogen for inerting, purging, and cooling

Ash/sorbent disposal costs are another variable O\&M cost. A disposal unit cost of $\$ 2.94 /$ ton was used for all cases, which is representative of current ash disposal costs being incurred by plants within The Southern Company.

The fixed O\&M components remain unchanged and consist of operating labor, supervision and clerical labor, maintenance material and labor, insurance and taxes, and general and administrative (G\&A) expenses. The basis for estimating these fixed costs is summarized in Table 5-5 and further described below.

The operating labor for all cases is based on estimates of the number of operating jobs required per shift as shown in Table 5-5. A shift multiplier of 4.2 is assumed. The labor rate of $\$ 21.80$ per hour includes a 40 -percent payroll burden and reflects an average O\&M labor rate appropriate for Plant Wansley. Under the assumptions for the Greenfield study, these labor rates were not changed. It should be noted that labor rates are also site specific and could change depending on the location of the Greenfield facility.

In the December 1990 report, supervision and clerical labor was estimated as 20 percent of the operating and maintenance labor. However, because this is a Greenfield site and all administrative and support labor will need to be provided, supervision and clerical is assumed to be 30 percent of the O\&M labor.

For studies ir which maintenance costs are not known from experience, the EPRI TAG recommends that total maintenance be estimated as a percentage of process plant costs. A maintenance material-to-labor ratio of $60 / 40$ is then 
applied to these costs. For the current study, however, maintenance labor costs were estimated directly from plant staffing plans. The annual maintenance labor cost is equal to the number of personnel times the burdened wage rate $(\$ 21.80$ /hour) times 1920 hours per year. Maintenance material costs were estimated based on a weighted average of percentages applied to individual process plant area costs as shown in Table 5-6.

These percentages were developed based on an analysis of The Southern Company O\&M costs as well as a number of published studies of gasificationbased power plants. The total annual maintenance cost is the sum of the maintenance labor and material estimates.

Table 5-5

Fixed O\&M Cost Basis

$\underline{\text { Item }}$

Maintenance material

Supervision and clerical

Insurance and taxes

G\&A expenses

Plant Staffing

Operating labor, persons/shift

Maintenance labor, total persons
Basis

Weighted average from projected percentage of area process capital

$30 \%$ of operating and maintenance labor

$0.6 \%$ of total plant cost

$10 \%$ of operating and maintenance labor
23

30
17

20
21

30 
Table 5-6

Maintenance Material Cost as Percentage of Process Plant Cost by Area

Area No. Area description

100 Coal receiving, handling

150 Limestone receiving, handling

250

300

380

400

500

600

700

900

1000

1100

1200

1300

Booster compression

KRW gasification

Recycle gas compression

Gas conditioning

External desulfurization

Sulfation

Sulfuric acid plant

Gas turbine system

HRSG system

Steam turbine system

Ash and fines handling and disposal

General facilities

Maintenance

Material

\% of PPC*

1.2

1.2

2.4

2.4

2.4

2.4

2.4

0.9

0.9

0.9

1.2

0.9

Weighted Averages, Maintenance Materials (\% of PPC)

Case $1 \quad 1.54$

Case $3 \quad 1.45$

Case $6 \quad 1.35$

* These percentages are applied to the sum of each area process plant cost and the prorated engineering fees, but excluding contingencies, to yield a total weighted average percent. The resulting value is multiplied by TPC to produce maintenance material costs. Maintenance labor costs are estimated based on plant staffing plans. 
Insurance and local taxes were calculated as a percentage of the total plant cost. A 0.6-percent value, based on The Southern Company data, is used. As in the December 1990 study, insurance and local taxes are included as an annual O\&M charge for calculation of cost of electricity, as is stipulated in the DOE cost model. The Southern Company accounting normally treats these as components of the capital carrying charge, which is consistent with the EPRI TAG approach.

No annual royalty costs are assumed for cases in this study. (Prepaid royalties were included as a capital cost item.)

The final annual cost is general and administrative expenses. These are estimated as 10 percent of O\&M labor and are a fixed O\&M cost component (Figure 5-3).

\subsubsection{Total and Net O\&M Cost Results}

The lowest first-year O\&M cost is for Case 6 at 20.23 mills $/ \mathrm{kWh}$. This is primarily a result of lower fuel and variable costs. Case 6 has the best predicted heat rate, which leads to the lowest fuel consumption and cost of the six cases (mills/kWh basis). Also, the predicted sulfur removal is better in the gasifier for Case 6, with less limestone consumption and no zinc ferrite system requirements; therefore, the variable costs are significantly less for Case 6. Case 1 has the next best O\&M cost at 22.42 mills $/ \mathrm{kWh}$, which represents an increase of approximately 10.8 percent over Case 6. As expected, the Greenfield O\&M costs are higher than in the site-specific study. For example, in the site specific study the first-year O\&M cost for Case 6 was 19.8 mills/kWh, which was 2.2 percent lower than the Greenfield site.

As shown in Table 5-7, fuel is the single highest production cost for all cases. Fuel costs range from 52 to 60 percent of the total O\&M (mills/kWh basis). Case 6 has the lowest proportion of variable costs at 5 percent of the total O\&M. As described above, this is a result of the reduced limestone consumption requirements in the gasifier and elimination of nahcolite and zinc ferrite consumption. 
Table 5-7

\section{First Year O\&M Cost Summary*}

Net MW $\left(90^{\circ} \mathrm{F}\right)$

Fuel, $\$ \times 1000$

Variable O\&M, \$X 1000

Limestone

Nahcolite

Zinc ferrite

Miscellaneous

Solids disposal

Total, \$ X 1000

Fixed O\&M, \& X 1000

Operating labor

Supervision

Maintenance

Insurance/taxes

Other

Total, \$ X 1000

Byproduct

Credit, $\$$ X 1000

Total First Year

O\&M Costs,

$\$ \mathrm{X} 1000$

Fuel, mills/kWh

Variable w/o

byproduct credit, mills/kWh

Fixed, \$/kW-yr

Total First Year

O\&M Costs

mills $/ \mathrm{kWh}$
Case 1 Case 3 Case 6

$\begin{array}{lll}458.4 & 231.7 \quad 409.6\end{array}$

$33,656 \quad 16,828 \quad 28,513$

$\begin{array}{rrr}2,885 & 1,441 & 1,182 \\ 296 & 148 & 0 \\ 1,648 & 824 & 0 \\ 595 & 360 & 703 \\ 859 & 429 & 557\end{array}$

$6,284 \quad 3,202 \quad 2,441$

$\begin{array}{rrr}4,380 & 3,238 & 3,999 \\ 1,691 & 1,222 & 1,577 \\ 8,921 & 5,166 & 7,470 \\ 3,019 & 1,768 & 2,645 \\ 564 & 407 & 526\end{array}$

$18,575 \quad 11,801 \quad 16,217$

$\begin{array}{lll}0 & 0 & 0\end{array}$

$58,514 \quad 31,832 \quad 47,171$

$\begin{array}{lll}12.89 & 12.76 & 12.23\end{array}$

$\begin{array}{lll}2.41 & 2.43 \quad 1.05\end{array}$

$\begin{array}{lll}38.3 & 47.7 \quad 37.2\end{array}$

$\begin{array}{lll}22.42 & 24.13 & 20.23\end{array}$

*Based on mid-1990 dollars and 65-percent capacity factor. Capacity factor of 65 percent specified by DOE for comparison to other studies. 


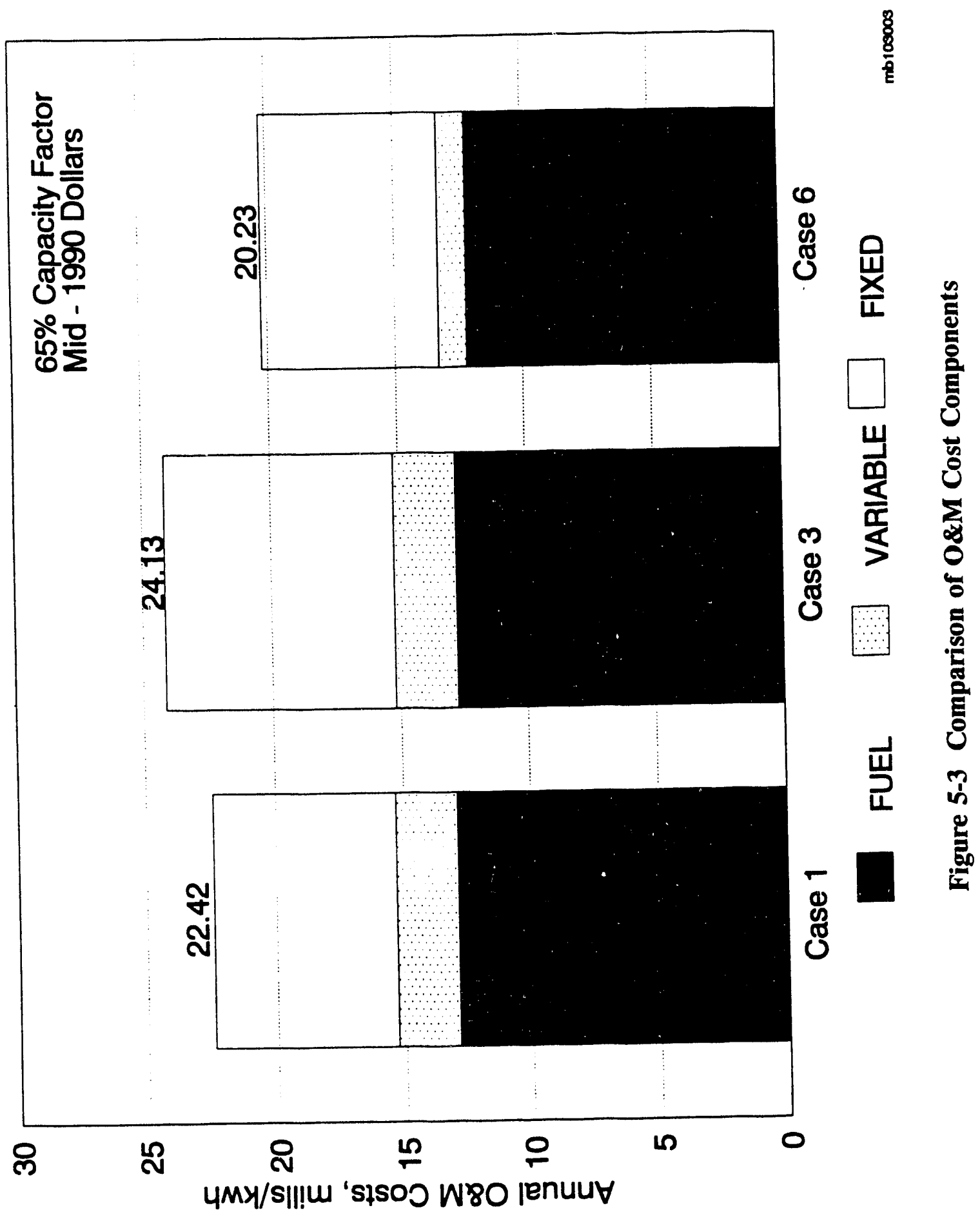




\subsection{COST OF ELECTRICITY DETERMINATION}

\subsubsection{Methodology}

The methodology for the cost of electricity (COE) determinations did not change for the Greenfield assessment. To evaluate the relative performance of the various study cases on a busbar cost basis, the ivelized COE was calculated using the cost data described in Section 5.2. The U.s. Department of Energy's cost-ofelectricity program, a Lotus 1-2-3 ${ }^{\mathrm{TM}}$ spreadsheet developed at METC, was used to calculate the COE for all cases. The DOE spreadsheet embodies standard busbar electricity cost calculations. The DOE spreadsheet has a number of built-in costing assumptions which are consistent with experience and utility costing approaches and is generally consistent with EPRI's Technical Assessment Guide (TAG).

The first two portions of the DOE spreadsheet calculate the total capital requirement and the net annual operating costs, based on the input and calculation methods described in the preceding section of this report. Upon completion of the data entry, the COE is also automatically calculated and displayed. The COE is stated in terms of 10-year levelized costs, in both current and constant dollars. The COE is broken down into capital, fuel, and operating and maintenance cost components.

\subsubsection{Assumptions}

The basic financial parameters assumed for COE calculation are given in Table 5-8. The project, book, and tax lives; the tax depreciation method; and the investment tax credit values were specified by the DOE COE method. The values listed for federal and state income tax rate and the financial structure are based on The Southern Company database for Georgia Power Company requirements. The inflation and escalation values are from SCS economic forecasts.

One of the most significant assumptions is the capacity factor of 65 percent. The assumption of a 65-percent capacity factor was stipulated by DOE to facilitate comparison with other study results. The capacity factors for these plants in The Southern Company system would be substantially higher.

The levelizing factors listed in Table 5-8 are calculated from the financial assumptions given in the same table. These factors are shown for both current and constant dollars and are for 10-year levelized costs. 
Table 5-8

Base Case Economic Assumptions for Cost of Electricity Calculation

Project life

Book life

Tax life

Federal and state income tax rate (composite)

Investment tax credit

Tax depreciation method

Inflation rate

Real escalation rates (over inflation)

Fuel

Operating \& maintenance

Year dollar basis

Capacity factor
30 years

30 years

30 years

$37.7 \%$

$0 \%$

ACRS

4.5\% per year

$0.5 \%$ per year

$0 \%$ per year

mid-1990

$65 \%$

Financial structure

\begin{tabular}{|c|c|c|c|c|c|}
\hline Type of Security & $\begin{array}{l}\% \text { of } \\
\text { Total }\end{array}$ & $\begin{array}{l}\text { Current } \\
\text { Cost }\end{array}$ & $\begin{array}{l}\text { Dollar, \% } \\
\text { Return }\end{array}$ & $\begin{array}{c}\text { Constant } \\
\text { Cost }\end{array}$ & $\begin{array}{l}\text { Dollar, \% } \\
\text { Return }\end{array}$ \\
\hline Debt & 45 & 10.3 & 4.6 & 5.6 & 2.5 \\
\hline Pre & 10 & 9.8 & 1.0 & 5.1 & 0.5 \\
\hline Common stoc & 45 & 13.8 & 6.2 & 8.9 & 4.0 \\
\hline
\end{tabular}

Discount rate, \%

(cost of capital)

11.8

7.0

Levelizing factors, (10-year)

Capital carrying charge

Current Dollar, \%

0.169

1.265

Constant Dollar, \%

Fuel

1.234

0.113

1.025

Operating \& maintenance

1.000 


\subsubsection{Summary: Total Costs of Electricity}

The COE results are presented in detail for each case in Appendix B and are summarized in Table 5-9. For comparative purposes, Table 5-9 also includes the previous COE for the site-specific study. The COE results are shown as 10-year levelized mills $/ \mathrm{kWh}$ costs, in both current and constant dollars, based on a 65 percent capacity factor. The comparisons discussed below are made on a constant dollar basis.

As with TCR and annual O\&M results, Case 6 possesses the lowest COE with 47.5 (constant \$), up from 45.6 mills $/ \mathrm{kWh}$ in the site-specific study. Case 1 is the next lowest with a COE of 50.8 mills $/ \mathrm{kWh}$, up from $49.1 \mathrm{mills} / \mathrm{kWh}$ in the sitespecific study. Most of the difference in COE for Case 6 versus the other cases is in its lower O\&M cost component, but also, to a lesser degree, its lower capital charges. The capital cost differences are a result of the predicted rapid gasification and sulfur capture reaction rates for the transport reactor, leading to reductions of the gasification island equipment and material costs, which in turn result in lower TCR and capital charges. In addition, the lower O\&M costs for Case 6 result from higher gasifier efficiency, reduced limestone usage, ard the elimination of nahcolite and zinc ferrite consumption.

The COE results in constant mills/kWh, are also presented graphically in Figure 5-4 for the Greenfield assessment. The figure illustrates that capital charges represent the single largest component of COE in all six cases. Capital charges range from 55 to 57 percent of the total COE. The fuel cost component is the second largest COE component. As in the original report, the dominance of capital charges in the COE results reinforce the importance of achieving capital cost reductions in gasification-based technologies.

Figure 5-5 presents a comparison of the Greenfield COE costs with the December 1990 site-specific study. As shown in the figure, the additional facilities only minimally impacted the COE for each case. The fuel costs were unchanged for the study and the O\&M costs changed only slightly. For Case 1, the COE increased the least, at 1.70 mills $/ \mathrm{kWh}$, an increase of only 3.46 percent. For Case 3 , the COE increase was the largest, at 2.6 mills $/ \mathrm{kWh}$ ( 4.8 percent), and for Case 6 the COE changed 1.90 mills/kWh (4.2 percent). 
Table 5-9

Levelized Cost of Electricity Summary*

CURRENT \$,

$$
\frac{\text { Case 1 }}{\text { Greenfield }} \quad \frac{\begin{array}{c}
\text { Case 1 } \\
\text { Site } \\
\text { Specific }
\end{array}}{\text { Greenfield }} \underset{\begin{array}{c}
\text { Case 3 } \\
\text { Specific }
\end{array}}{\frac{\text { Case 6 6 }}{\text { Greenfield }}} \frac{\text { Case 6 }}{\begin{array}{c}
\text { Site } \\
\text { Specific }
\end{array}}
$$

mills $/ \mathrm{kWh}$

\begin{tabular}{|c|c|c|c|c|c|}
\hline Capital Charges & 41.8 & 39.8 & 48.1 & 45.1 & 40.1 \\
\hline Fuel Costs & 16.3 & 16.3 & 16.1 & 16.1 & 15.5 \\
\hline $\begin{array}{l}\text { Operating \& } \\
\text { Maintenance }\end{array}$ & 11.7 & 11.3 & 14.0 & 13.3 & 9.9 \\
\hline $\begin{array}{l}\text { Total Cost } \\
\text { of Electricity }\end{array}$ & 69.8 & 67.4 & 78.3 & 74.5 & 65.5 \\
\hline
\end{tabular}

CONSTANT \$, mills/kWh

$\begin{array}{lllllll}\text { Capital Charges } & 28.0 & 26.7 & 32.3 & 30.3 & 26.9 & 25.5\end{array}$

$\begin{array}{lllllll}\text { Fuel Costs } & 13.2 & 13.2 & 13.1 & 13.1 & 12.5 & 12.5\end{array}$

Operating \&

Maintenance

$\begin{array}{llllll}9.5 & 9.1 & 11.4 & 10.8 & 8.0 & 7.6\end{array}$

Total Cost

of Electricity

$\begin{array}{llllll}50.8 & 49.1 & 56.8 & 54.2 & 47.5 & 45.6\end{array}$

* Ten-year levelized at 65-percent capacity factor with mid-1990 dollar basis.

$\begin{array}{lll}\text { Case } 1 & \text { KRW IGCC } & 458 \mathrm{MW} \\ \text { Case } 3 & \text { KRW IGCC } & 232 \mathrm{MW} \\ \text { Case } 6 & \text { TRANSPORT IGCC } & 410 \mathrm{MW}\end{array}$




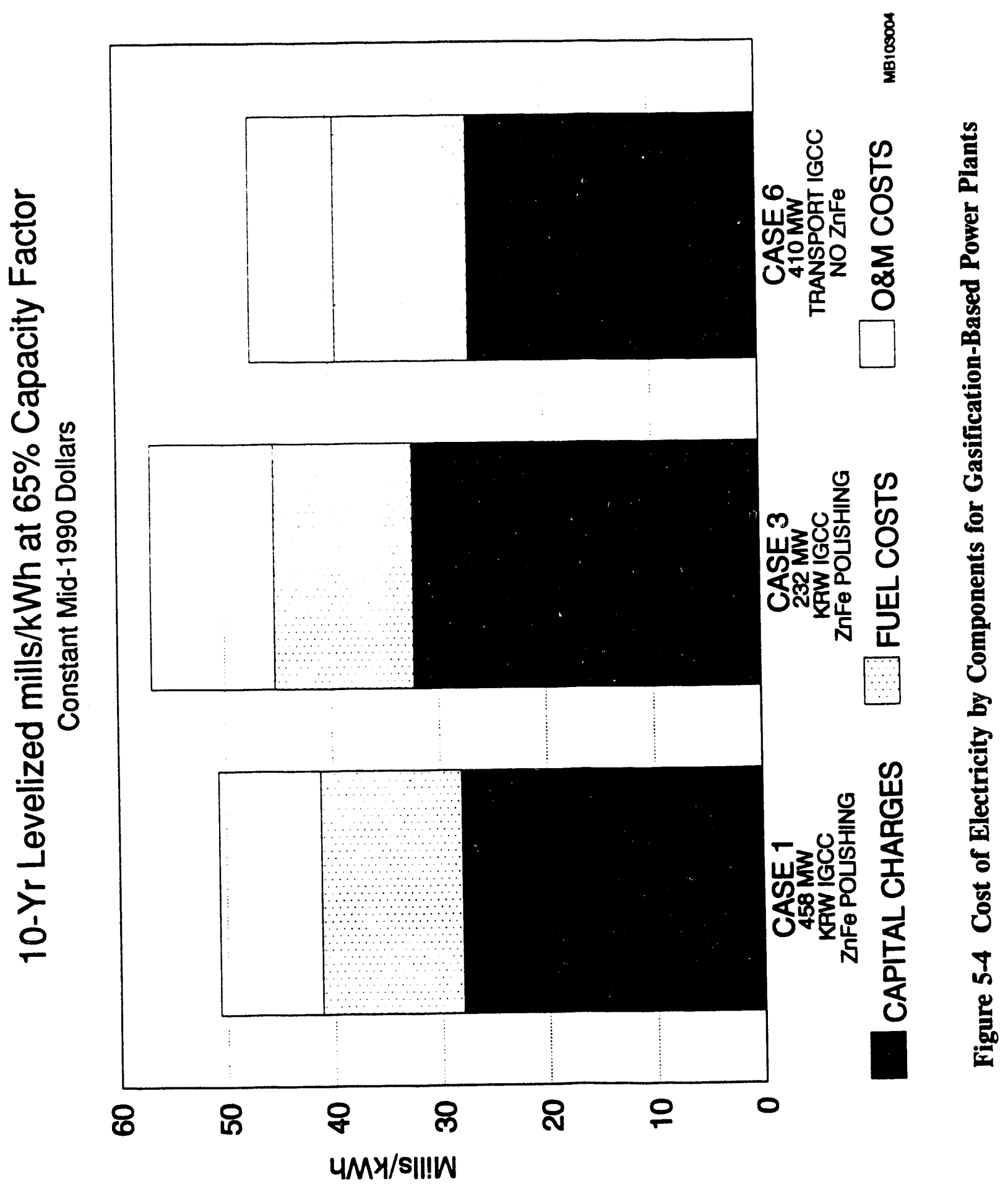




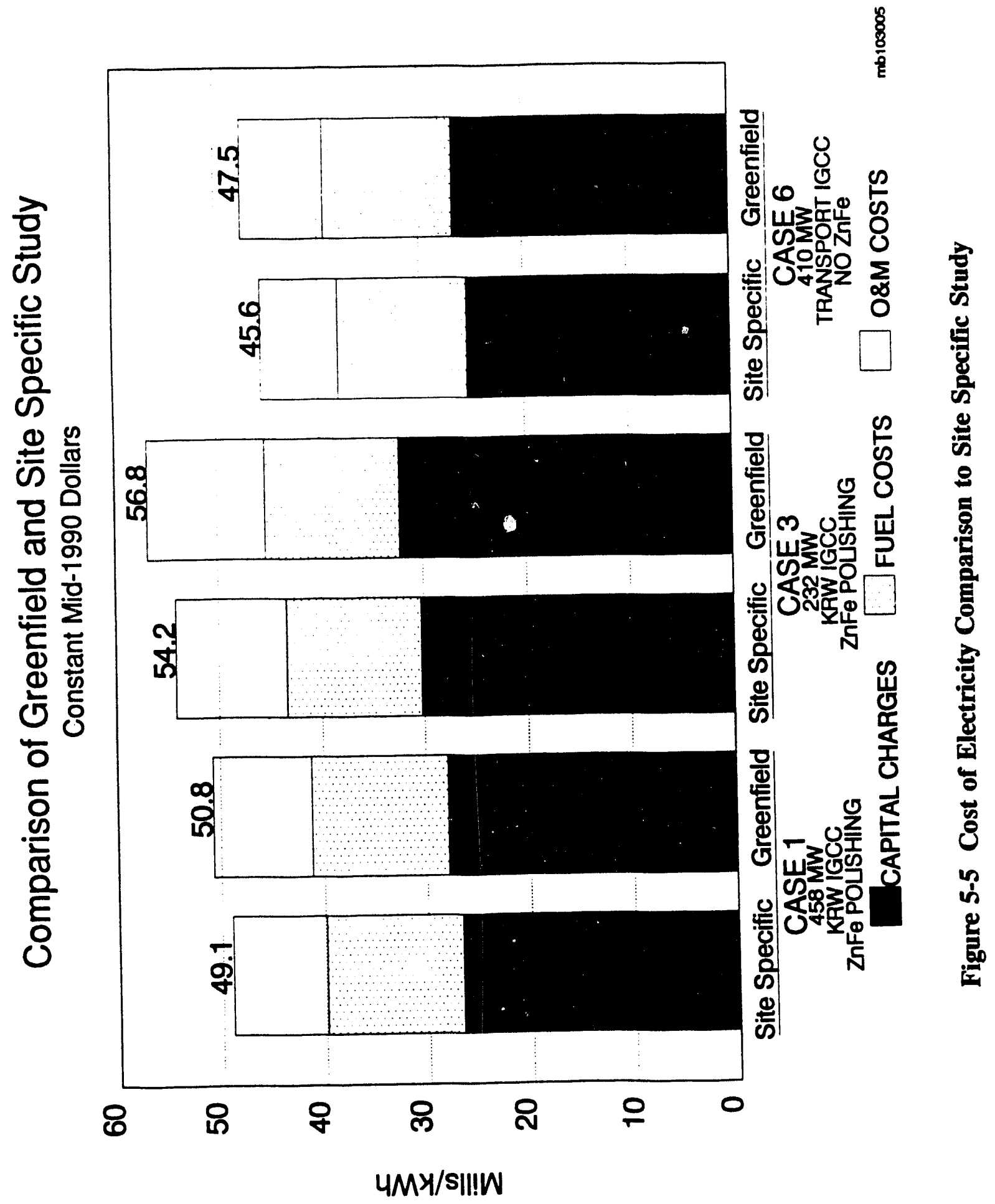




\subsection{CONCLUSIONS AND RECOMMENDATIONS}

The objective of this fo."'owup report is to evaluate and compare Cases 1, 3, and 6 air-blown gasification power plants with hot gas cleanup, to determine a Greenfield cost estimate for these plant configurations. Case 6, with the transport reactor, was considered for this study because it projects the lowest costs of electricity. However, it is important to note that the transport reactor is not as commercially developed as the KRW gasifier used in Cases 1 and 3. Additions to the original site-specific plants for the Greenfield assessment included:

- Land ard he cost of land acquisition

- Coal unloading and coal storage facilities

- Roads and railroad facilities

- General offices and adrininistration

- Ash disposal facilities

Based on the Greenfield assessment, the following conclusions and recommendations were derived.

- Greenfield costs for IGCC cases 1, 3, and 6 cost of electricity increased only $3.46,4.80$, and 4.17 percent to 50.8 mills $/ \mathrm{kWh}, 56.8$ mills $/ \mathrm{kWh}$ and $47.5 \mathrm{mills} / \mathrm{kWh}$, respectively, from the original sitespecific IGCC study.

- Total capital requirement for Cases 1, 3, and 6 Greenfield assessment increased to $\$ 1408 / \mathrm{kW}$ ( $\$ 645.3$ million), $\$ 1623 / \mathrm{kW}$ ( $\$ 376.0$ million), $\$ 1353 / \mathrm{kW}$ ( $\$ 554.0$ million), respectively. This TCR increasing on the average of 5.83 percent over the site-specific study.

- The first year O\&M costs for the Greenfield sites were 22.42 mills $/ \mathrm{kWh}$ for Case $1,24.13$ mills $/ \mathrm{kWh}$ for Case 3 , and 20.23 mills/kWh for Case 6 . The site-specific study for Case 6 had a first year O\&M cost of $19.8 \mathrm{mills} / \mathrm{kWh}$, which was 2.2 percent lower than the Greenfield assessment.

- $\quad$ Environmental permitting can be much more difficult for a Greenfield electric generating facility than additional permitting for a modification to an existing facility.

- $\quad$ Additional TCLP tests should be conducted on LASH samples to ensure that no hazardous waste will be generated using the MWK gasifier. 


\section{REFERENCES}

1. Gallaspy, D.T., Jihnson, J.W. and Sears, R.E., "Southern Company Services Study of a KRW--3ased Integrated-Gasification-Combined-Cycle Plants," GS-6876, Research Project 2773-5, Final Report, Electric Power Research Institute, Palo Alto, California, July 1990.

2. Southern Company Services, et al., "Assessment of Coal Gasification/Hot Gas Cleanup Based Advanced Gas Turbine Systems," DOE-METC Contract No. DE-FC21-89MC26019, Final Report, December 1990.

3. GR1-85/0123 Environmental, Health and Safety Data Base performed by the Radian Corporation for the Gas Research Institute, August 1982 - June 1985.

4. Peterson, D.L., and Zein, C.T., "Wastewater Treatment for IGCC Power Plants," AIChE Summer National Meeting, August 1986.

5. Kolp, D.A., and Moeller, D. J., "World's First Full STIG ${ }^{\mathrm{TM}}$ LM-5000 Installed at Simpson Paper Company," American Society of Mechanical Engineers Paper No. 88-GT-198, Gas Turbine and Aeroengine Congress and Exposition, Amsterdam, The Netherlands, June 5-9, 1988.

6. Corman, J.C., "System Analysis of Simplified IGCC Plants, "Topical Report 86SRDO11, U.S. DOE Contract No. DE-AC21-80ET14928, General Electric Company, Schenectady, New York, September 1986.

7. "Coal Gasification Systems: A Guide to Status, Applications and Economics," AP-3109, Electric Power Research Institute, Palo Alto, California, June 1983.

8. FE-21063-30, U.S. Department of Energy Contract No. DE-AC21-84MC21063 Topical Report - Characterization of Solid Waste, May 15, 1987. 


\section{LIST OF ACRONYMS AND ABBREVIATIONS}

A

$\mathrm{ABD}$

AFUDC

APHA

ASPEN

BACT

BOD

CDP

COD

COE

CT

CTG

DOE

DOE/METC

EA

ED

EERC

EFOH

EFOR

EP

EPA

EPRI

FGD

FICA

FOR

GNPIPD

GPC

HHV

HP
Availability

Availability Block Diagrams

Allowance for Funds During Construction

American Public Health Association

Computer Simulation Model

Best Available Control Technology

Biological Oxygen Demand

Compressor Discharge Bleedair Port

Chemical Oxygen Demand

Cost of Electricity

Combustion Turbine

Combustion Turbine Generator

U.S. Department of Energy

U.S. Department of Energy/Morgantown Energy Technology Center

Equivalent Availability

Energy Destruction

Energy and Environmental Research Center

Equivalent Forced Outage Hours

Equivalent Forced Outage Rate

Extraction Procedure

U.S. Environmental Protection Agency

Electric Power Research Institute

Flue Gas Desulfurization

Federal Insurance Corporation of America

Forced Outage Rate

Gross National Product Implicit Price Deflator

Georgia Power Company

Higher Heating Valve

High Pressure 
LIST OF ACRONYMS AND ABBREVIATIONS, CONT.

HPC

HRSG

IGCC

IP

IP/LP

ISCST

ISTIG

JTU

KRW

LASH

LHV

LP

MWK

NAAQS

NSPS

O\&M

PC

PFBC

POF

PPC

PROMOD

PROVAL

PSD

R\&EA

RAM

RCRA

R.G.

SCOT

SCR
High-Pressure Compressor

Heat Recovery Steam Generator

Integrated Gasification Combined Cycle

Intermediate Pressure

Intermediate Pressure/Low Pressure

Industrial Source Complex Short Term

Intercooled Steam-Injected Gas Turbine

Jackson Turbidity Units

KRW Energy Systems

Limestone-Containing A.sh

Lower Heating Valve

Low Pressure

The M.W. Kellogg Company

National Ambient Air Quality Standards

New Source Performance Standards

Operation and Maintenance

Pulverized-Coal

Pressurized-Fluidized-Bed Combustion

Planned Outage Factor

Process Plant Cost

Computer Simulation Model

Cost Analysis and Financial Computer Software Application Prevention of Significant Deterioration

Research and Environmental Affairs

Reliability-Availability-Maintainability

Resource Conservation Recovery Act

Recycle Gas

Tailgas Treatment System

Selective Catalytic Reduction 
APPENDIX A

PLANT DESCRIPTION AND DETAILS

CASES 1, 3, and 6 


\section{APPENDIX A PLANT DESCRIPTION AND DETAILS - CASES 1, 3, and 6}

\section{A.1 INTRODUCTION}

The IGCC system configurations for Cases 1,3, and 6 are similar in that all three cases have the same combined-cycle power island configuration. The three cases differ in either plant size or design of the gas island. The differences in the gas island design are in the desulfurization method or the type of gasifier used for the plant design. Cases 1 and 3 use the KRW gasifier and Case 6 uses the transport gasifier.

This Appendix provides detailed descriptions of the design and performance of the three IGCC study cases, including:

- Process descriptions

- Material balances

- Plant layouts and equipment arrangements

- RAM analysis results

- Plant performance

Cost and economic data for the designs are presented in subsequent sections.

\section{A.2 AIR-BLOWN IGCC WITH KRW GASIFICATION, BULK SULFUR REMOVAL IN THE GASIFIER (CASES 1 AND 3)}

\section{A.2.1 Process Description}

Cases 1 and 3 both utilize bulk sulfur removal with limestone in the KRW gasifier, with a zinc ferrite polishing step for additional sulfur removal. The main difference between the two cases is the plant size. Case 1 was specified as a $400-\mathrm{MW}$ plant and Case 3 is half that size at nominally $200 \mathrm{MW}$. Both cases have essentially the same process steps with only the number of process trains varying for each case. Both cases are thus grouped together in the discussion that follows.

\section{A.2.1.1 Overall Process Arrangement}

The block flow diagrams for Cases 1 and 3 are shown in Figures A-1 and A-2, respectively. Case 1 has four separate processing trains for the gas island with two combustion turbines and heat recovery steam generators (HRSGs) and one steam turbine for the power island. Case 3, at half the size, has only two processing trains for the gas island and a single combustion turbine, HRSG, and steam turbine power island train. The corresponding stream flows for the stream numbers indicated on Figures A-1 and A-2 are listed in Table A-1 and A-2. 

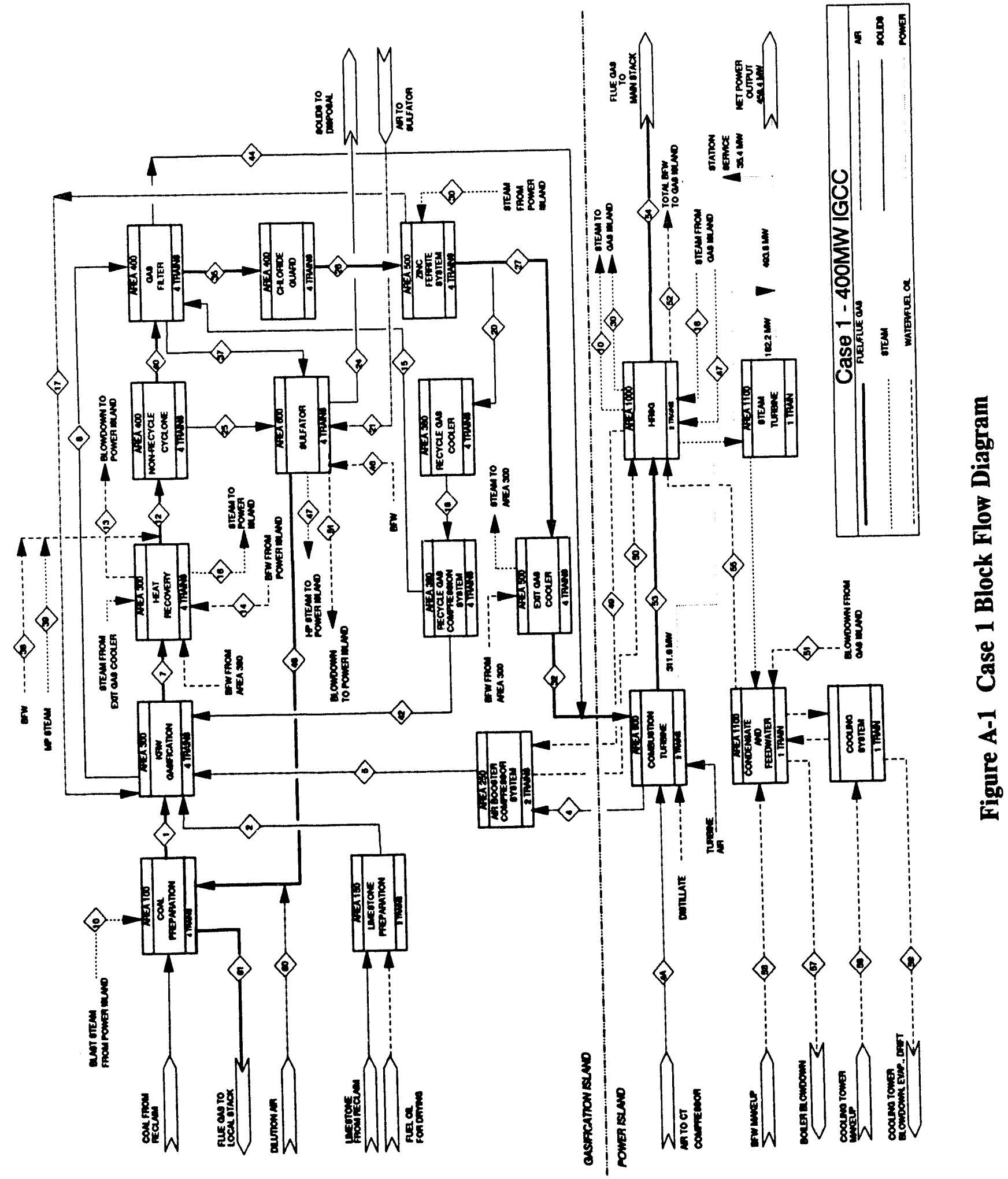
Assessment of Coal Gasification/Hot Gas

Cleanup Based Advanced Gas Turbine Systems

Appendix A of Greenfield Assessment

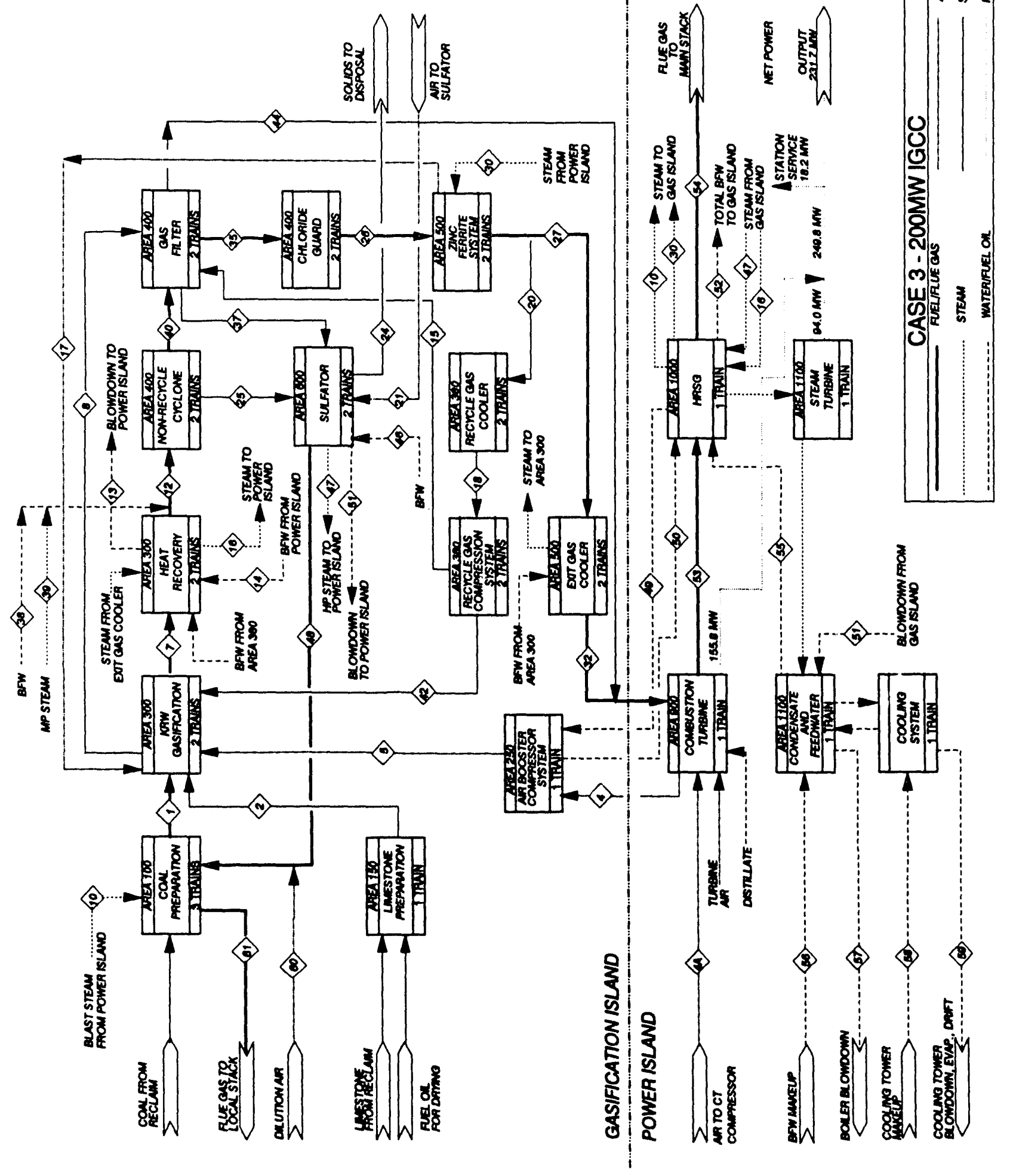

是 


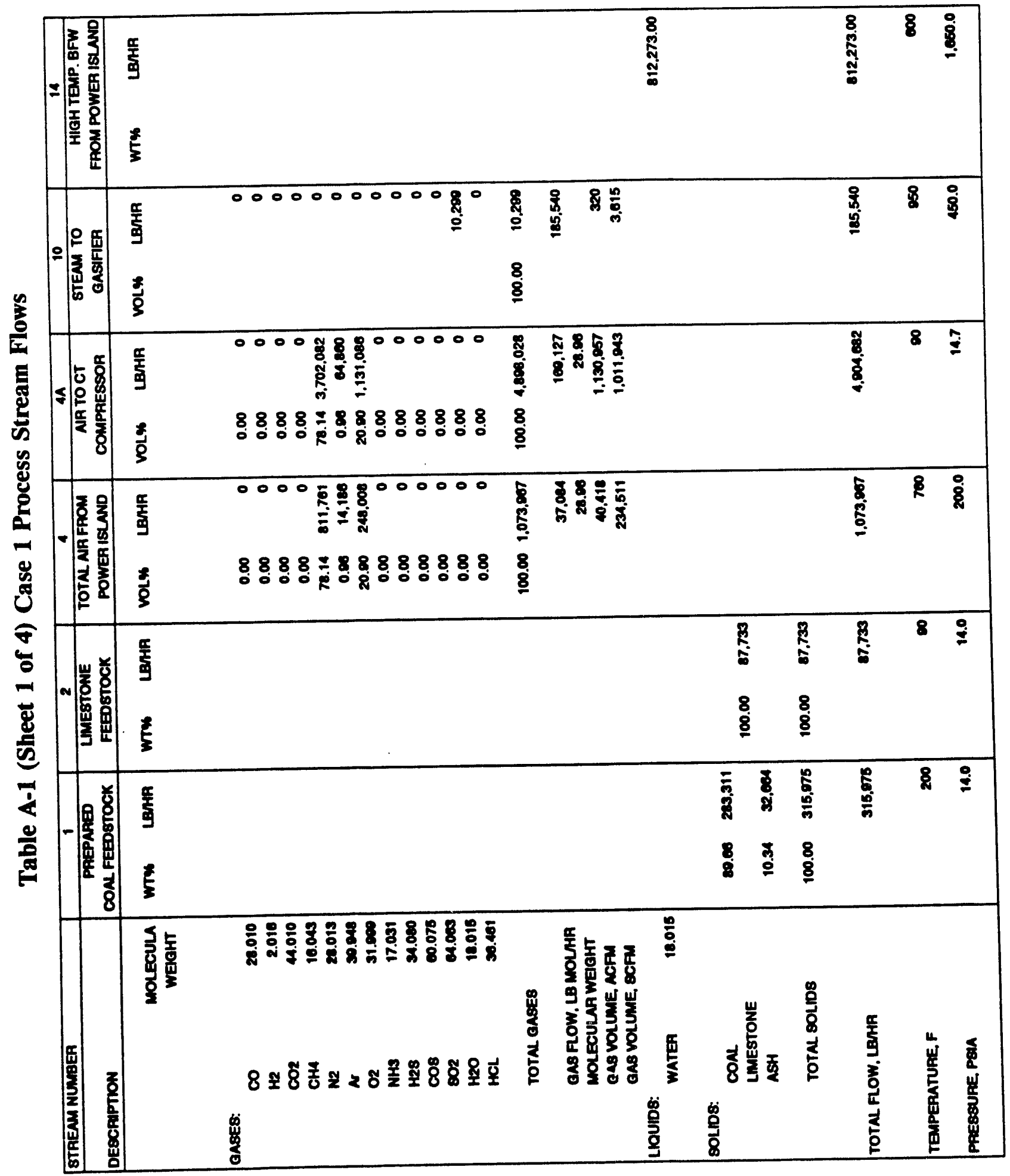




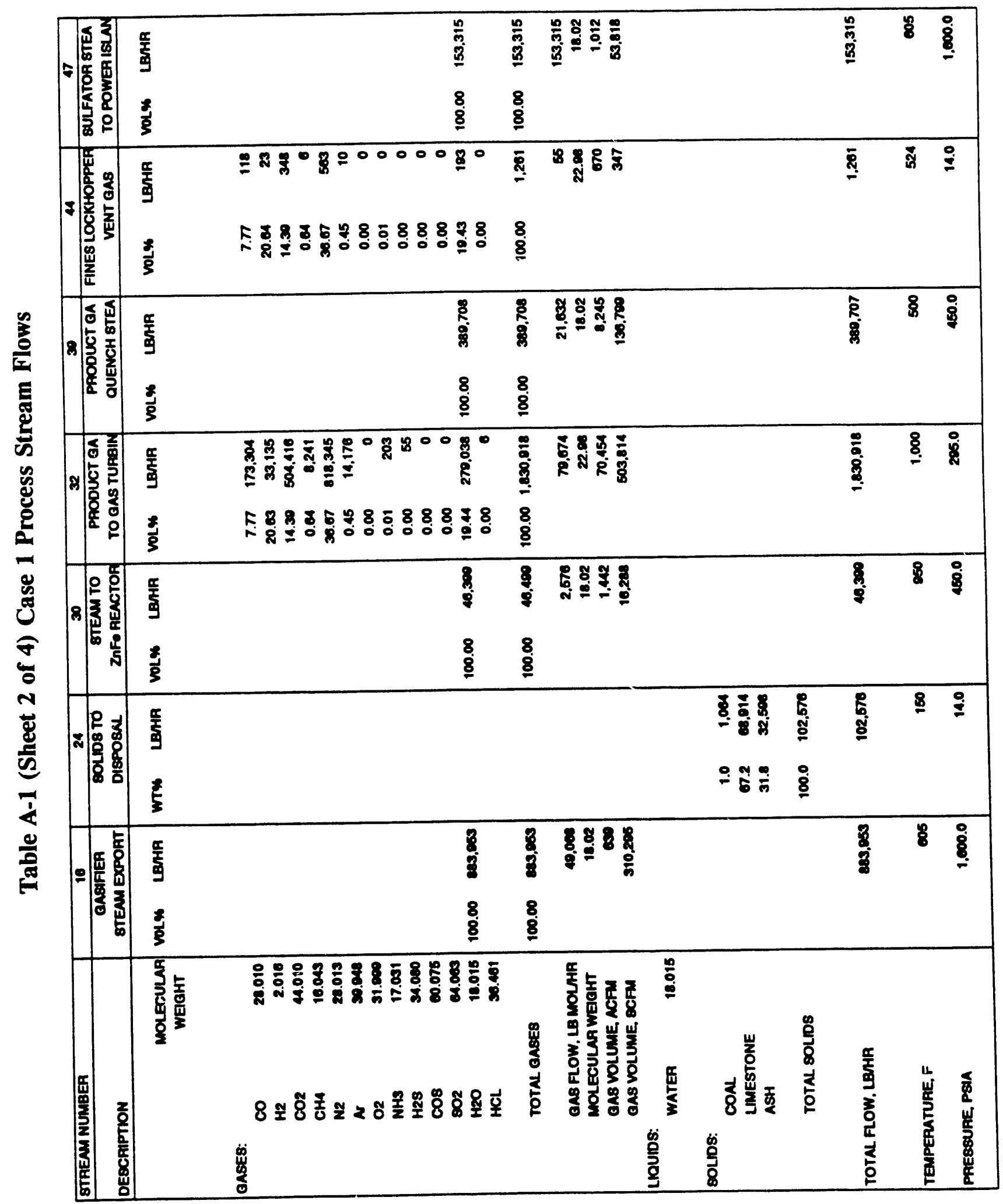


Assessment of Coal Gasification/Hot Gas

Cleanup Based Advanced Gas Turbine Systems

Appendix A of Greenfield Assessment

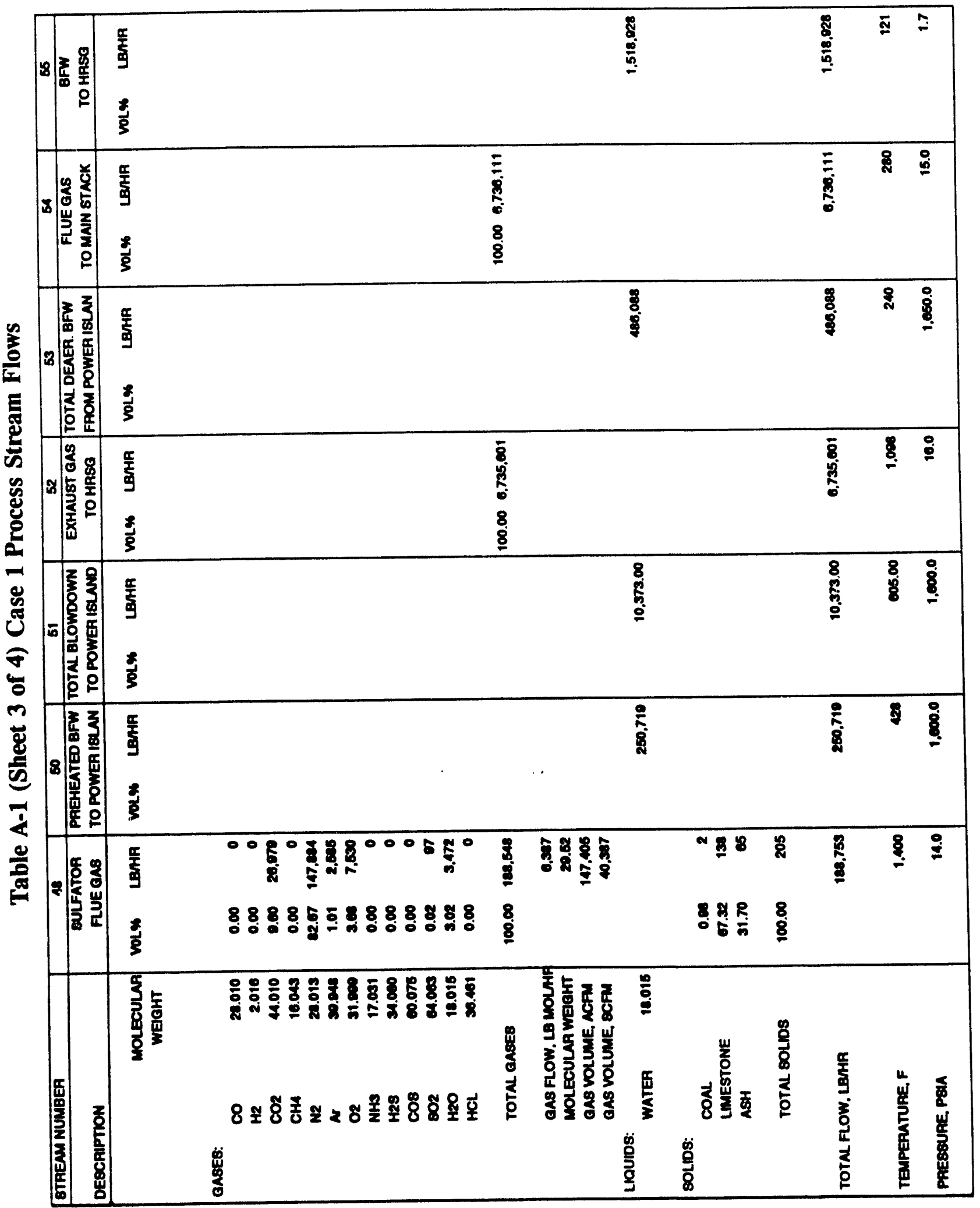




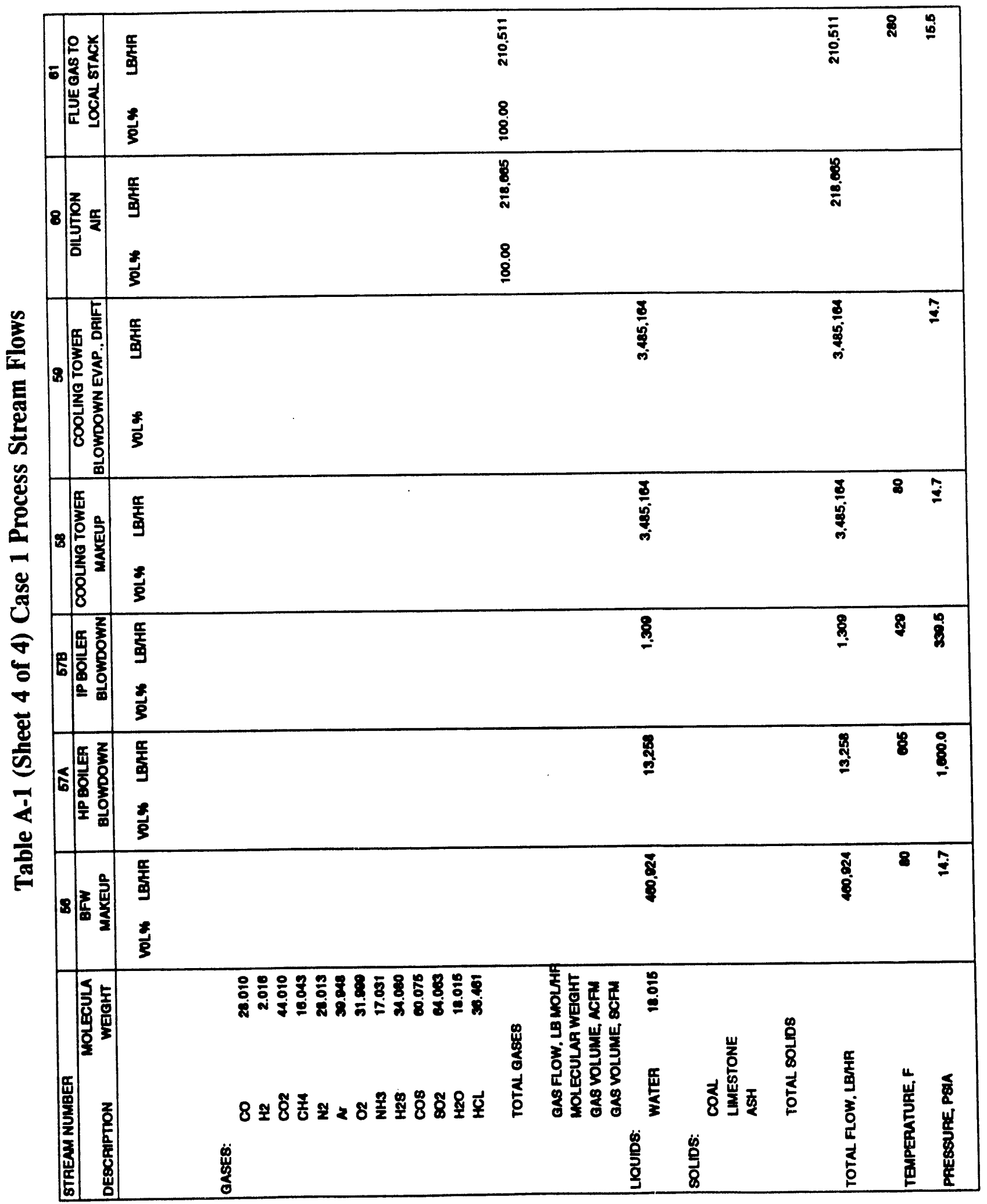


Assessment of Coal Gasification/Hot Gas

Cleanup Based Advanced Gas Turbine Systems

Appendix A of Greenfield Assessment

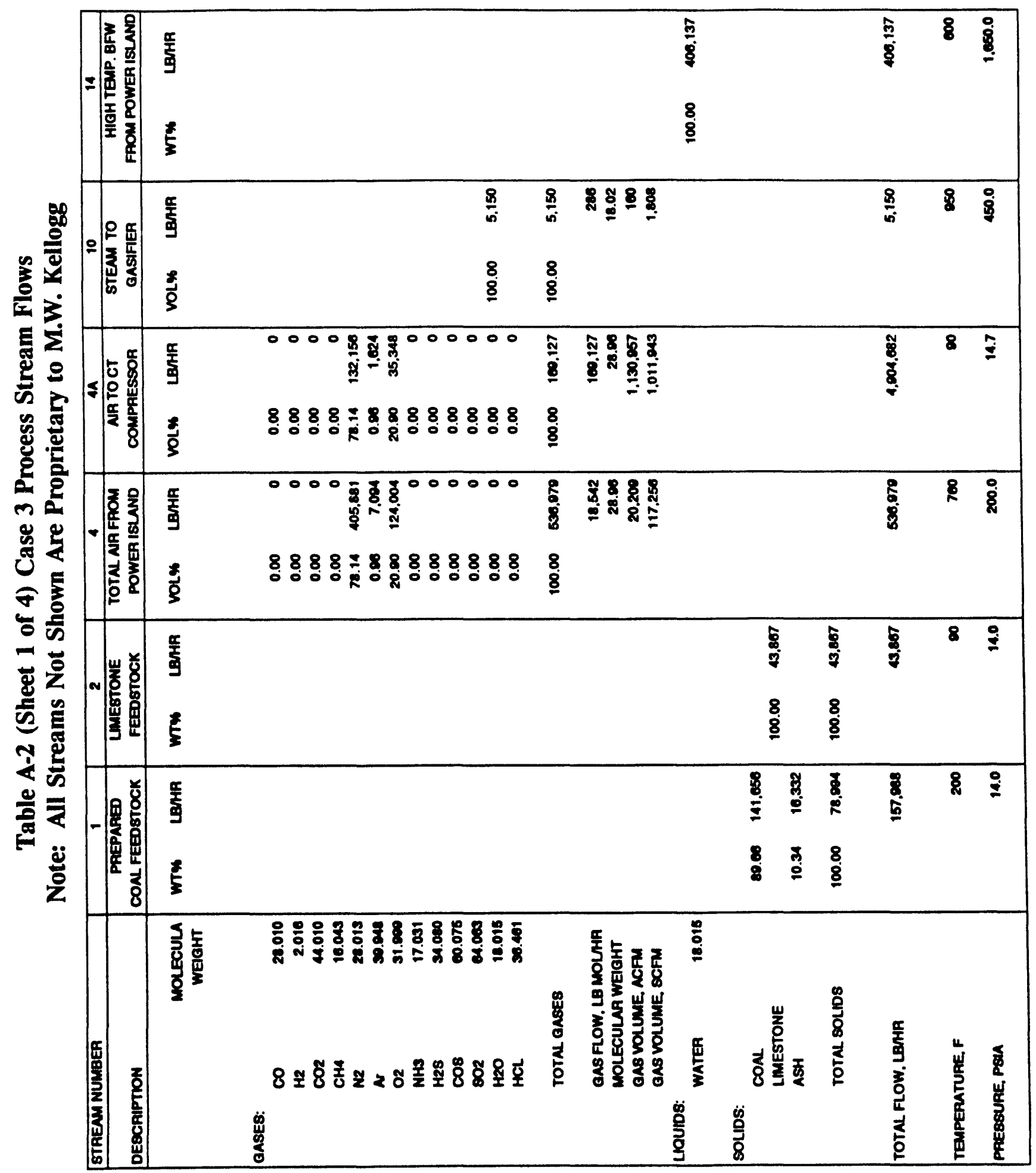




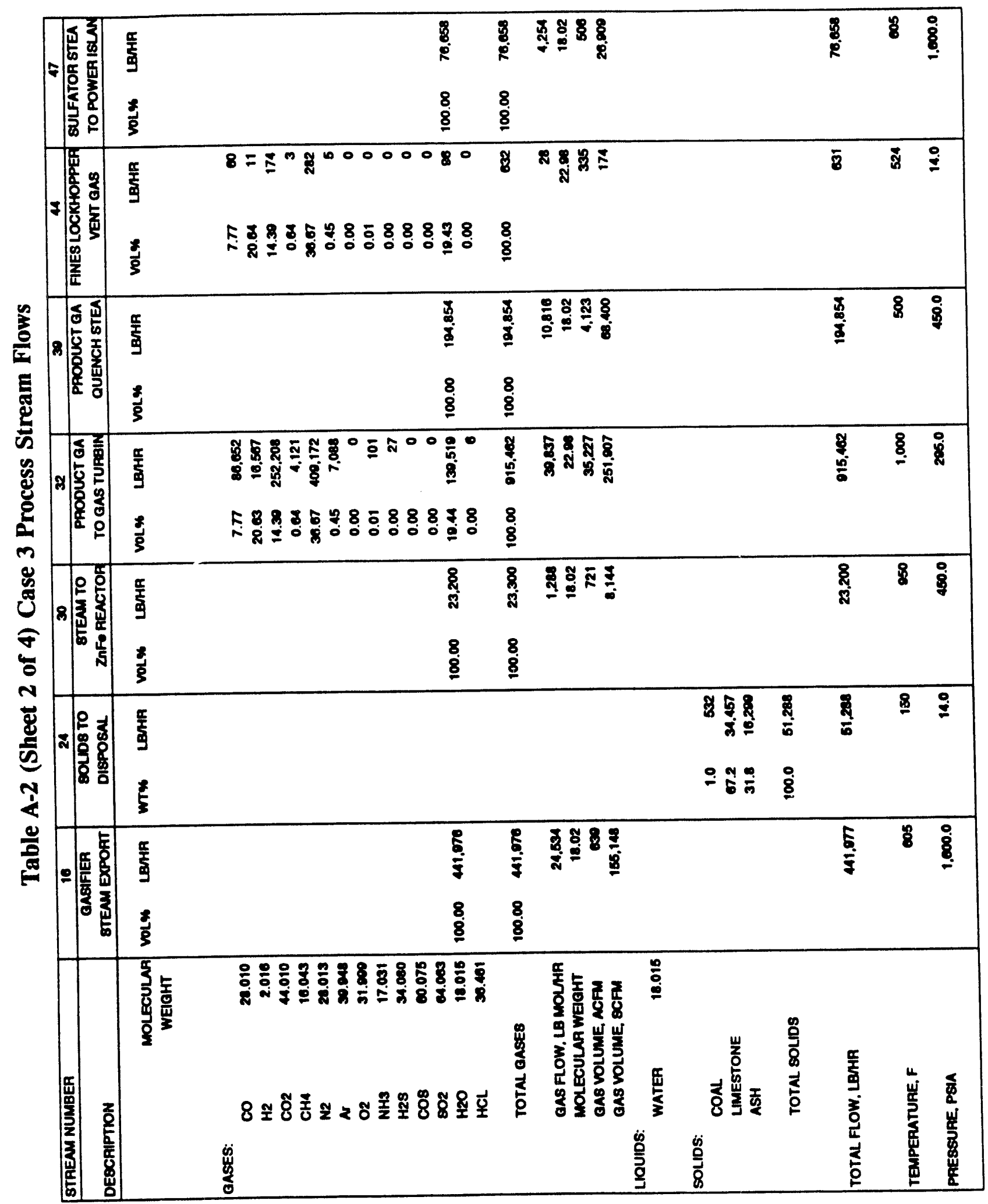


Assessment of Coal Gasification/Hot Gas

Cleanup Based Advanced Gas Turbine Systems

Appendix A of Greenfield Assessment

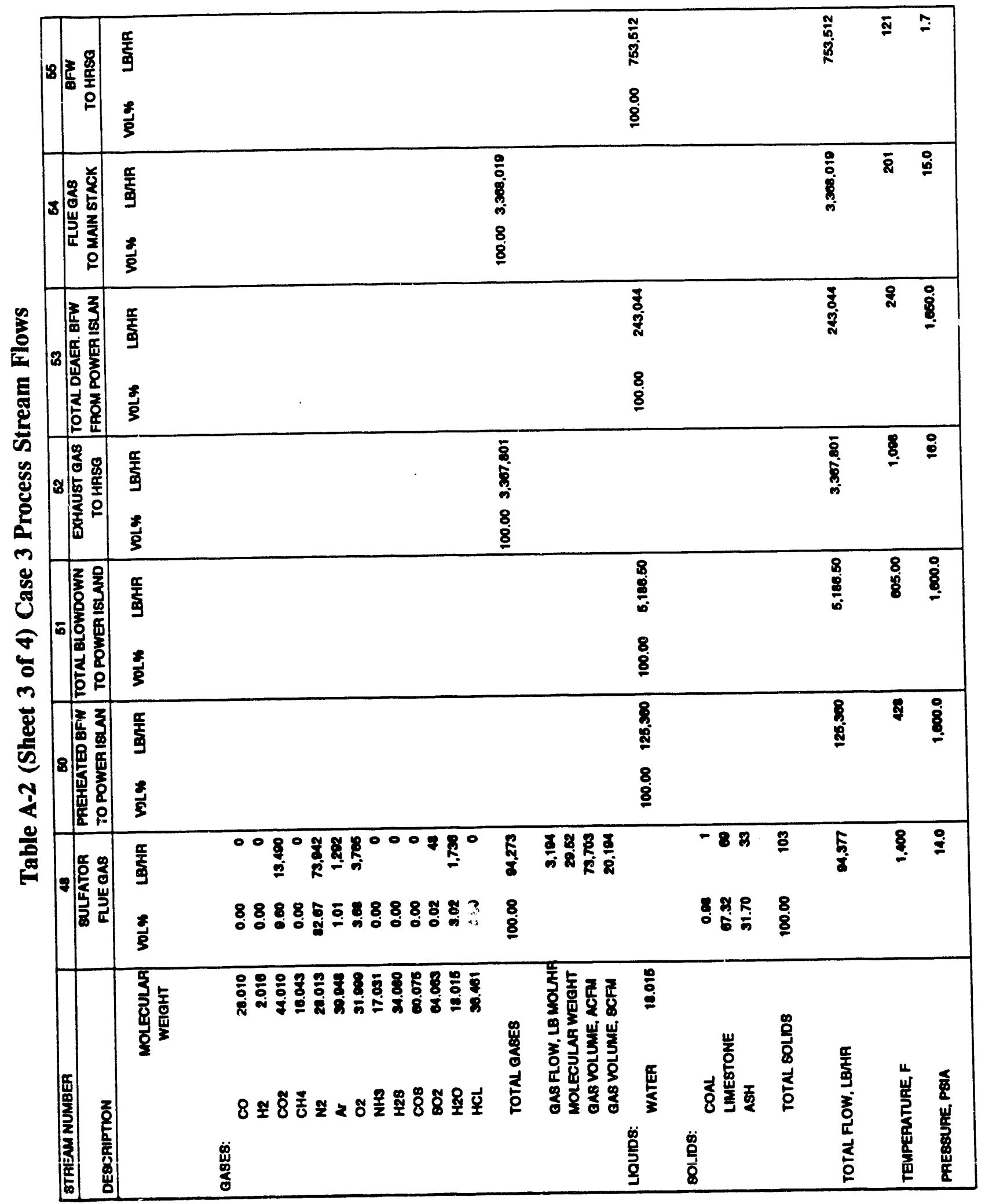




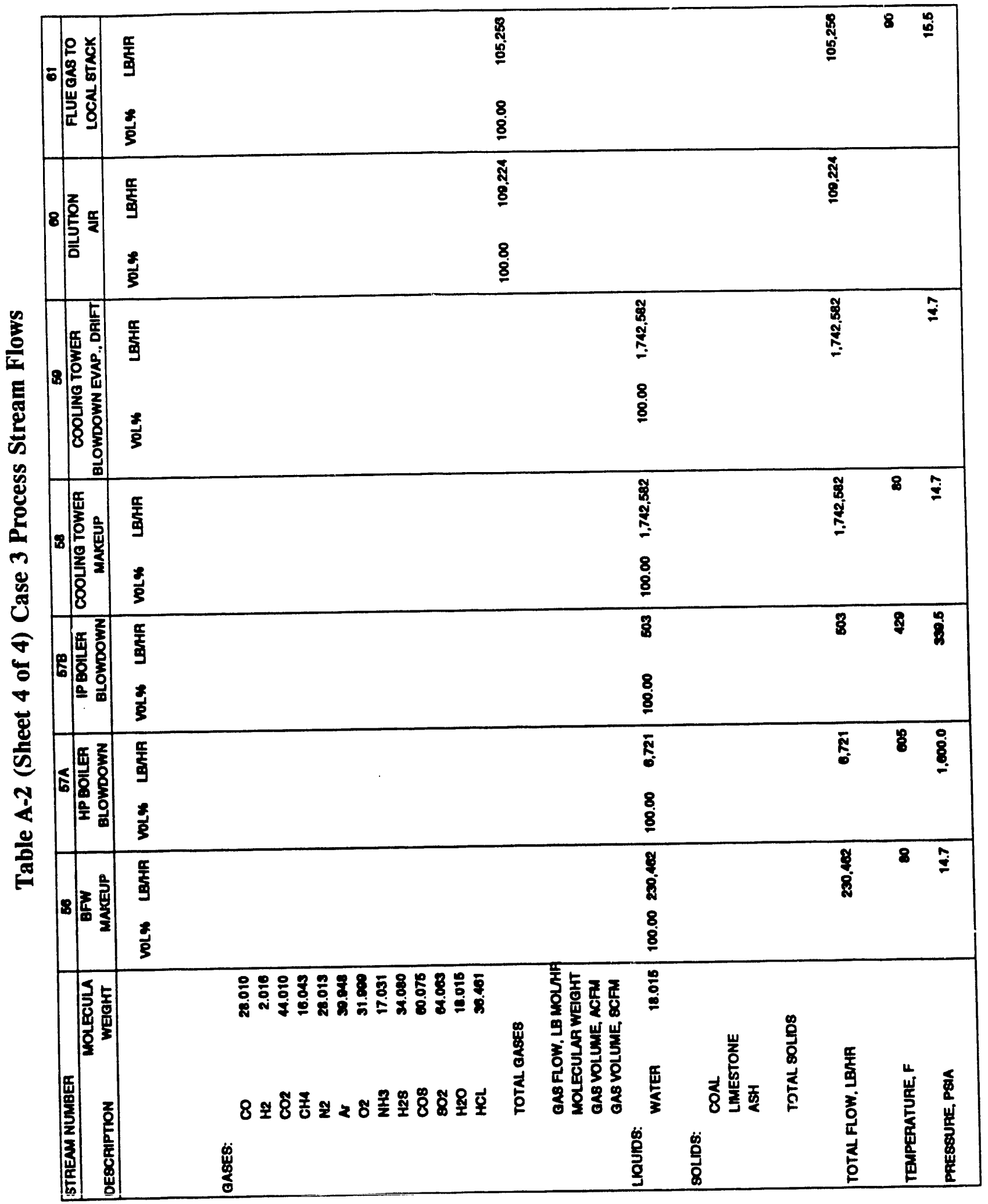


Assessment of Coal Gasification/Hot Gas

Cleanup Based Advanced Gas Turbine Systems

Appendix A of Greenfield Assessment

For both Cases 1 and 3, the coal and limestone are sized and dried prior to being fed into the KRW gasifier. Flue gas from the sulfator is used to dry the feed coal, whereas an oil-fired heater is used to dry the limestone. The product gas from the gasifier is cooled to nominally $1,000^{\circ} \mathrm{F}$ prior to entering a cyclone, which removes the coarse particulates from the product gas, and a high-temperature ceramic filter, which removes fine particulates. Both the coarse and fine particulates are fed to the sulfator for the conversion of calcium sulfide to calcium sulfate in the limestone and ash (LASH) from the gasifier. The limestone in the gasifier serves as the bulk desulfurization step of the process.

After hot gas filtration of particulates, the product gas passes through a chloride guard bed prior to entering the zinc ferrite polishing system for removal of additional sulfur from the product gas. The chloride guard is essential for removing chloride from the fuel gas, since chloride can severely affect the structural integrity of the zinc ferrite sorbent. After the exothermic zinc ferrite step, the clean product gas is cooled to $1,000^{\circ} \mathrm{F}$ prior to entering the power island.

The cleaned product gas from the gas island is combusted in either one (Case 3) or two (Case 1) GE MS7001F gas turbines to produce the majority of the power for the power island. Air for the gasifier is initially compressed to 200 psia in the gas turbine compress sr, followed by additional pressurization in a booster compressor, to deliver air at the proper pressure for the gasifier. The $1,100^{\circ} \mathrm{F}$ flue gas from the gas turbine is sent to a HRSG (one for each gas turbine) to produce steam for additional power produced in a single steam turbine, as well as steam for the gas island. The flue gas from the HRSG is sent to the main power plant stack.

\section{A.2.1.2 Coal and Limestone Receiving, Handling, and Preparation}

The coal handling systems for both Cases 1 and 3 use the existing unit train coal unloading system at the Plant Wansley site. Figure A-3 and Figure A-4 are process flow diagrams of the coal and limestone preparation systems for Cases 1 and 3. Twenty-eight new vibrating feeders are installed in the existing reclaim tunnel under the unloading trestle. All equipment beyond the vibrating feeders is dedicated to the IGCC plant. After unloading, the coal is passed by a magnetic separator as it is conveyed by six conveyors to four coal storage silos for Case 1 and three coal storage silos for Case 3 .

Next, the coal is simultaneously crushed and dried in fluidized-bed roller mills. Case 1 has three mills, with a fourth serving as a spare. Case 3 has a total of two operating pulverizers, with one spare. The heat for coal drying is provided by flue gas from the sulfator in the gasifier island. The flue gas, at $1,400^{\circ} \mathrm{F}$, is first cooled to a temperature suitable for coal drying by mixing with recycle gas from the pulverizer/dryer along with a quantity of air, resulting in a drying gas with a maximum of 12-percent oxygen by volume at a temperature of $500^{\circ} \mathrm{F}$. For startup, and oil-fired heater provides the heat for coal drying. 


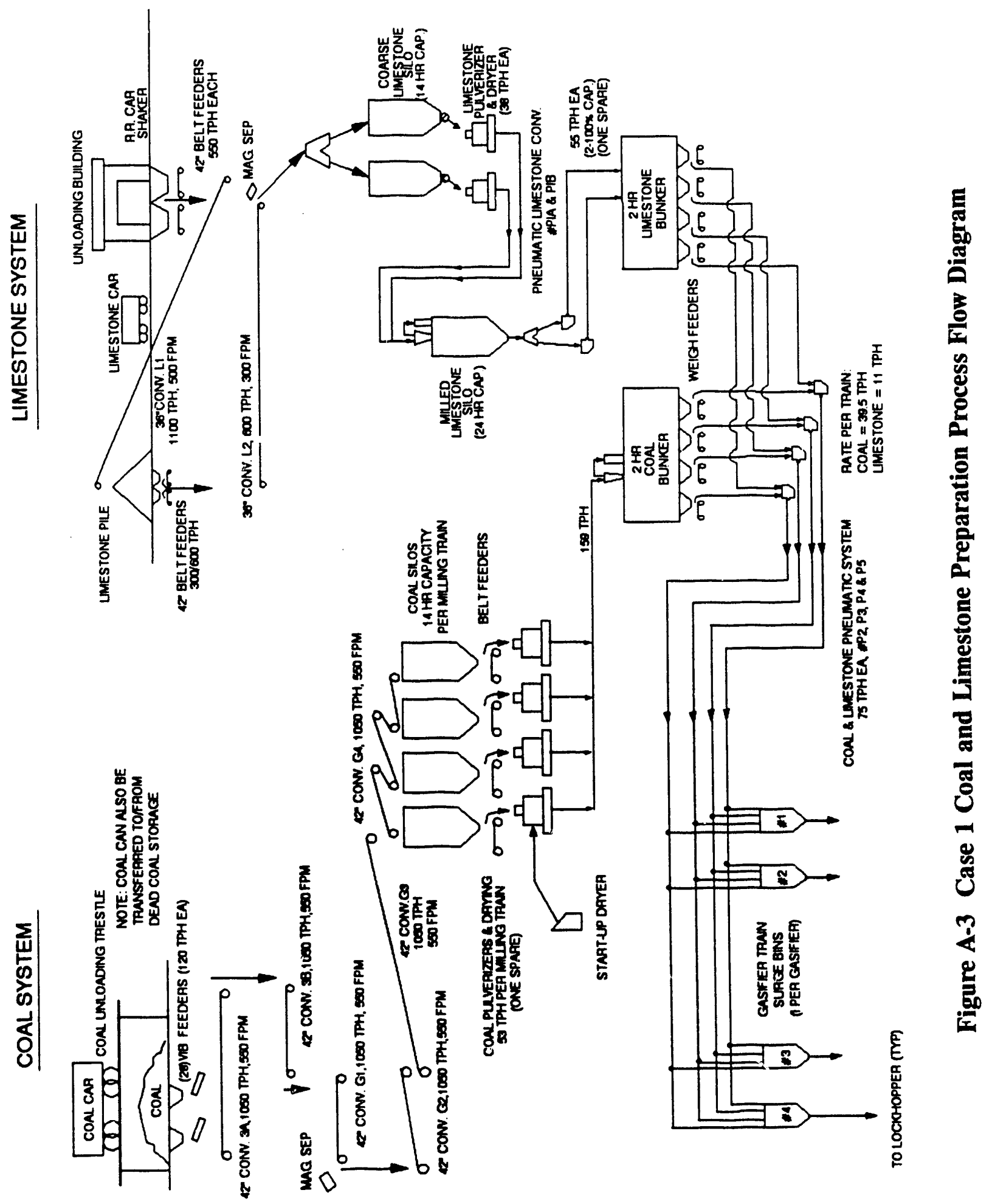



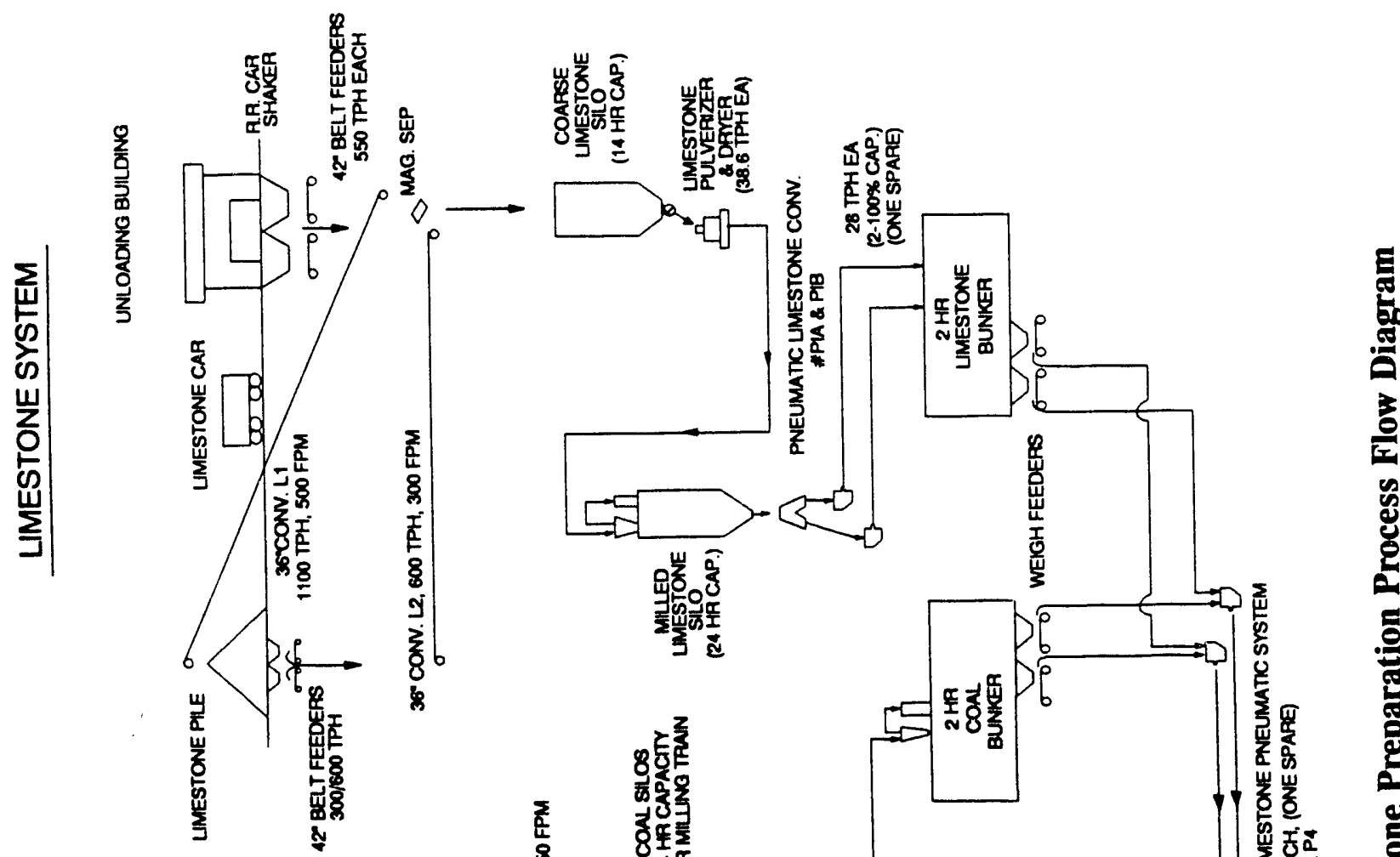

是
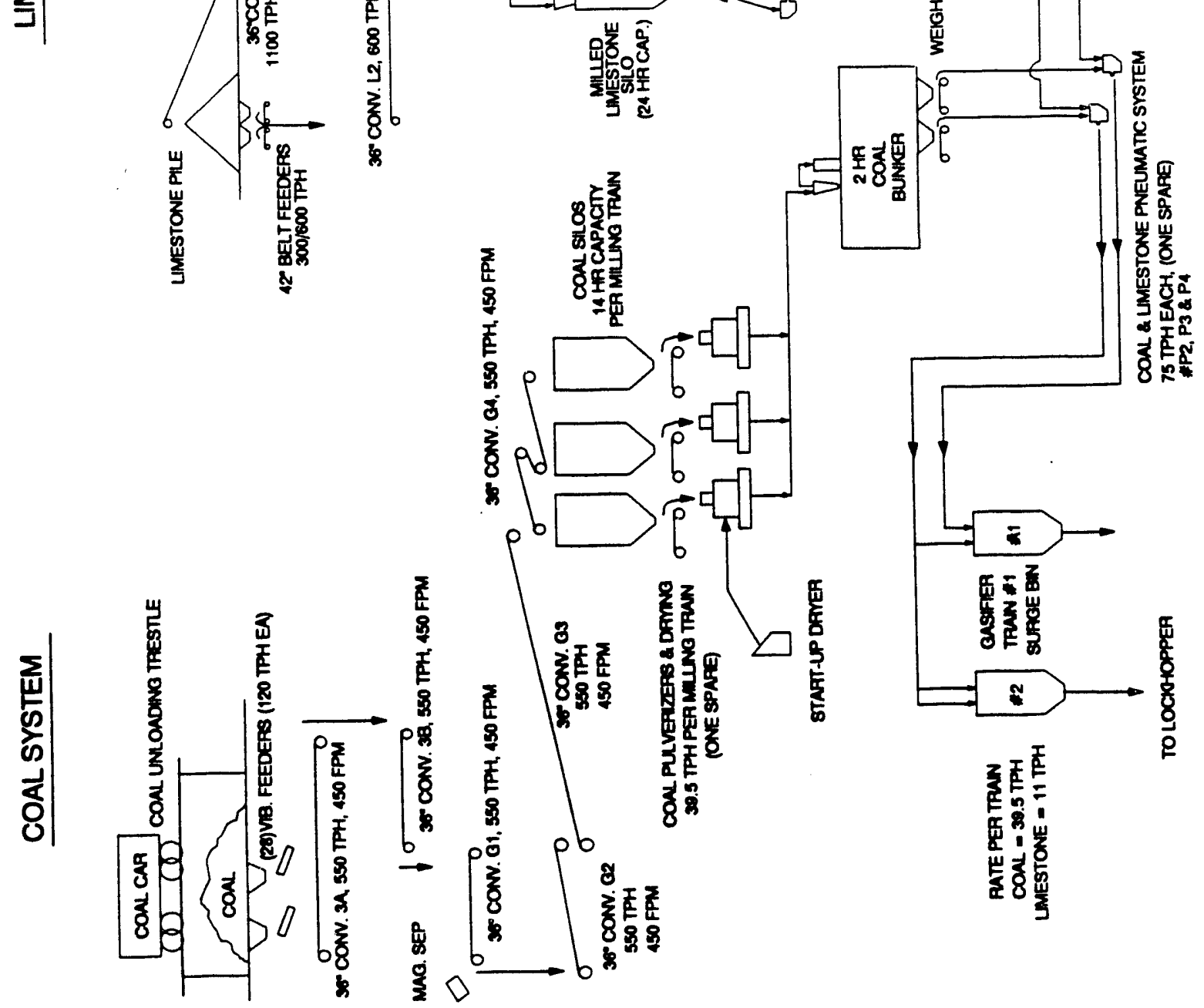
After preparation, the coal is transported to coal and limestone bunkers and then fed with weigh feeders into bins where the coal and limestone are combined. Pneumatic conveying systems are then used to transport the coal/limestone mixture to surge bins located in the gasifier structures. In order to increase reliability/availability, each of the weighing and pneumatic systems is capable of filling any of the surge bins. Case 1 has a total of four pneumatic conveying systems, one of which is a spare. Case 3 has a total of two operating pneumatic conveying systems for the coal/limestone mixture, one serving as a spare.

The limestone system for both cases uses an existing railroad track adjacent to the IGCC plant site. The rail car system consists of a covered single car-receiving hopper with a car shaker and two belt feeders. The belt feeders discharge onto a conveyor, which forms a 50-foot-high pile adjacent to a 60-day storage pile. A dust suppression system is used at the receiving hopper and the stockout conveyor. The limestone reclaim system has two reclaim hoppers located under the live storage pile. A slide gate and a belt feeder are located at the bottom of each hopper. The belt feeders discharge onto a conveyor which transports the limestone to two storage silos.

The limestone from the storage silos is fed into two pulverizers for Case 1 and one pulverizer for Case 3, where it is dried with the heat supplied by an oil-fired heater. The pulverizers are operated two shifts per day, with the third shift used for maintenance. Limestone from the pulverizers is collected in a storage silo with a storage capacity sufficient for 24 hours of operation. Two pneumatic conveying systems (one spare) transport the limestone to the common coal/limestone bunker. From this point, the coal and limestone share a common transport system to the surge bin located in the gasifier structure.

\section{A.2.1.3 Air Compression and Supply}

This system consists of two subsystems: the boost air compression system and the lockhopper air compression system. The subsystems are described separately below.

\section{Boost Air Compression (Area 250)}

The boost air compression system provides the air necessary for gasifier operation and for regeneration of the zinc ferrite desulfurizer. (Details of this system are provided in Subsection A.2.1.6.) Air for this system is obtained by extraction from the compressor of the gas turbine located in the power island.

Air from the gas turbine compressor discharge is first cooled in the air recuperator. This exchanger simultaneously cools the relatively high-temperature air obtained from the gas turbine and heats the compressor discharge air before delivery to the gasifier. After the initial air cooling is accomplished, a boiler feedwater (BFW) preheater and a trim cooler are employed to cool the air to a lower temperature for more efficient air compression. 
Assessment of Coal Gasification/Hot Gas

Cleanup Based Advanced Gas Turbine Systems

Appendix A of Greenfield Assessment

Before entering the compressor, a knockout drum is provided at the compressor suction to remove condensed moisture.

\section{Lockhopper Air Compression}

This subsystem is included as part of Area 300, Gasification. A separate air compressor is provided for lockhopper pressurization, as shown in Figure A-5. The compressor is sized for the average flow required by the lockhoppers. To accommodate the large periodic flows to the lockhoppers, a surge vessel is included.

\section{A.2.1.4 Coal Gasification and Recycle Gas Compression}

This area consists of five functional subsystems: coal/sorbent pressurization, gasification, ash removal, heat recovery, and recycle gas compression. The subsystems are described separately below.

\section{Coal/Sorbent Pressurization}

Figure A-5 is a process flow diagram of the gasification step for Cases 1 and 3. A conventional lockhopper system is used to pressurize the coal and limestone mixture. The two feedstocks are mixed in a single surge bin in the coal and limestone preparation steps. This bin operates at atmospheric pressure and serves as a reserve of raw material for the pressurizing lockhoppers locat:d beneath the bin.

The feed-pressurization lockhopper periodically receives coal from the feed surge bin. Two valves are used between the vessels: the upper valve to initiate or stop solids flow and the lower to provide a gas-tight seal. After a batch of coal is received, the feed pressurization lockhopper is pressurized with high pressure air. When the pressure in the lockhopper is equalized with the feed hopper, a valve located beneath the pressurization hopper is opened to dump the material into the feed hopper. When the lockhopper is empty, the valve is closed and the lockhopper is vented to atmospheric pressure to repeat the cycle.

The vent filter is installed on the pressurizing/venting line to essentially eliminate particulate emissions when the pressurization hopper is vented. The lockhopper is pressurized through this same filter to provide an automatic backflushing of the filter media.

The feed hopper is operated at a constant pressure sufficient to permit starwheel feed metering and pneumatic conveying of the coal/limestone mixture to the gasifier by an air 


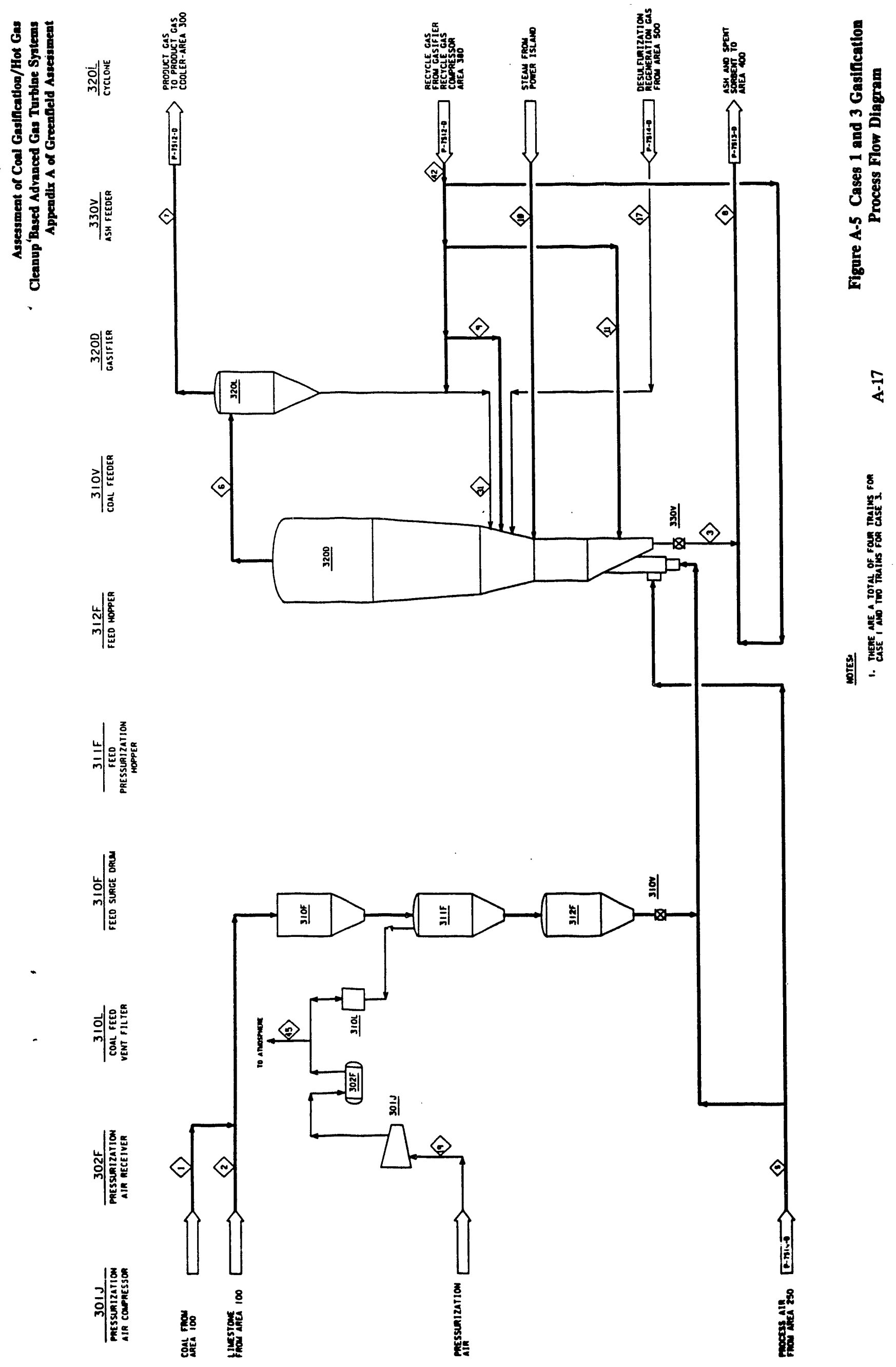


stream. The relative proportions of coal and limestone sent to the surge bin will be established by setpoint adjustments based on an analysis of the gasifier product gas obtained from an online sulfur analyzer.

\section{Gasification}

The coal is gasified in a KRW pressurized-fluidized-bed gasifier. The gasifier is a refractory-lined carbon steel pressure vessel, divided $i$ to a number of functional zones, where the necessary processes of coal devolatilization, combustion, gasification, desulfurization, and ash and spent sorbent cooling occur.

Coal and limestone are pneumatically fed to the gasifier through a central feed tube. Additional air is also fed through this same feed tube and the streams merge to form a central jet where the coal is quickly devolatilized with the remaining char and limestone entering the bed. Combustion of char and gas occurs within the jet to provide the heat necessary for endothermic devolatilization, gasification, calcination, and desulfurization chemical reactions.

Within the bed a number of competing reactions occur. The principal reactions of interest are the gasification reactions:

$$
\begin{aligned}
& \mathrm{C}+\mathrm{H}_{2} \mathrm{O} \rightarrow \mathrm{CO}+\mathrm{H}_{2} \\
& \mathrm{C}+\mathrm{CO}_{2} \rightarrow 2 \mathrm{CO}
\end{aligned}
$$

These reactions occur between the gas-phase steam and combustion products and the carbon in the char. Carbon monoxide and hydrogen form the major combustible constituents of the product gas. Methane and other hydrocarbons are produced in lesser quantities, primarily from the devolatilization process. The operating temperature of the gasifier is sufficiently high to crack any tars or oils that might be produced.

The fluidized bed also presents a favorable environment for desulfurization of the gas. Hydrogen sulfide, produced from the sulfur in the coal, is the primary sulfur species and is removed from the gas phase by the following reaction:

$$
\mathrm{CaO}+\mathrm{H}_{2} \mathrm{~S} \rightarrow \mathrm{CaS}+\mathrm{H}_{2} \mathrm{O}
$$

Calcium oxide is obtained by the calcination or decomposition of limestone according to:

$$
\mathrm{CaCO}_{3} \rightarrow \mathrm{CaO}+\mathrm{CO}_{2}
$$

This reaction occurs very quickly when the limestone reaches the bed due to the low $\mathrm{CO}_{2}$ partial pressure in the gasifier. As the carbon in the char is consumed, the particles become enriched in ash. The ash particles then tend to adhere to each other and agglomerate and, along with the dense calcium sulfide/oxide particles, separate from the 
Assessment of Coal Gasification/Hot Gas

Cleanup Based Advanced Gas Turbine Systems

Appendix A of Greenfield Assessment

char bed because of their different fluidization characteristics. This separation occurs primarily in a region that surrounds the central feed tube at the bottom of the gasifier vessel.

Gas leaves the gasifier at the top of the vessel and enters a cyclone. The cyclone separates the majority of the fine particulates that escape the gasifier bed and returns them to the bed by a fluidized dipleg.

The startup heater is a natural-gas-fired heater that provides hot air necessary for the initial heatup and combustion in the gasifier. The heater is designed to provide air at $100^{\circ} \mathrm{F}$ during the startup phase. This is a standard industrial combustor, with all necessary auxiliaries included.

\section{Ash Removal}

Ash and spent sorbent are removed from the gasifier by the ash feeder. The material is then conveyed from the gasifier area to the bottom of the gas filter where it is mixed with the fines collected by a filter.

\section{Heat Recovery}

Heat recovery is accomplished in two exchangers, the product gas cooler and the recycle gas cooler. Figure A-6 is a process flow diagram of the heat recovery step for Cases 1 and 3. The product gas from the gasification area is partially cooled by the product gas cooler. Gas exiting the cooler is additionally cooled by steam/water quench. The amount of quench is determined by the desired moisture content of the gas, and desired mixed-steam temperature is controlled by an internal bypass of the gas cooler.

The second exchanger, the recycle gas cooler, is used to cool gas that is recycled to the gasifier and that which is used for blowback of the gas filter. The outlet gas temperature of the recycle gas cooler is controlled by the flow of boiler feedwater to the cooler.

\section{Recycle-Gas Compression}

A two-stage, recycle-gas-compression system is employed. The high-pressure stage supplies high-pressure recycle gas to be used for filter blowback and lockhopper pressurization. A gas receiver is included to provide the surge capacity necessary to accommodate the periodic gas flows to the depressurization hopper and the filter. Gasifier fluidization and ash-transport gas is provided by the low-pressure, high volume stage of the recycle gas compressor. 


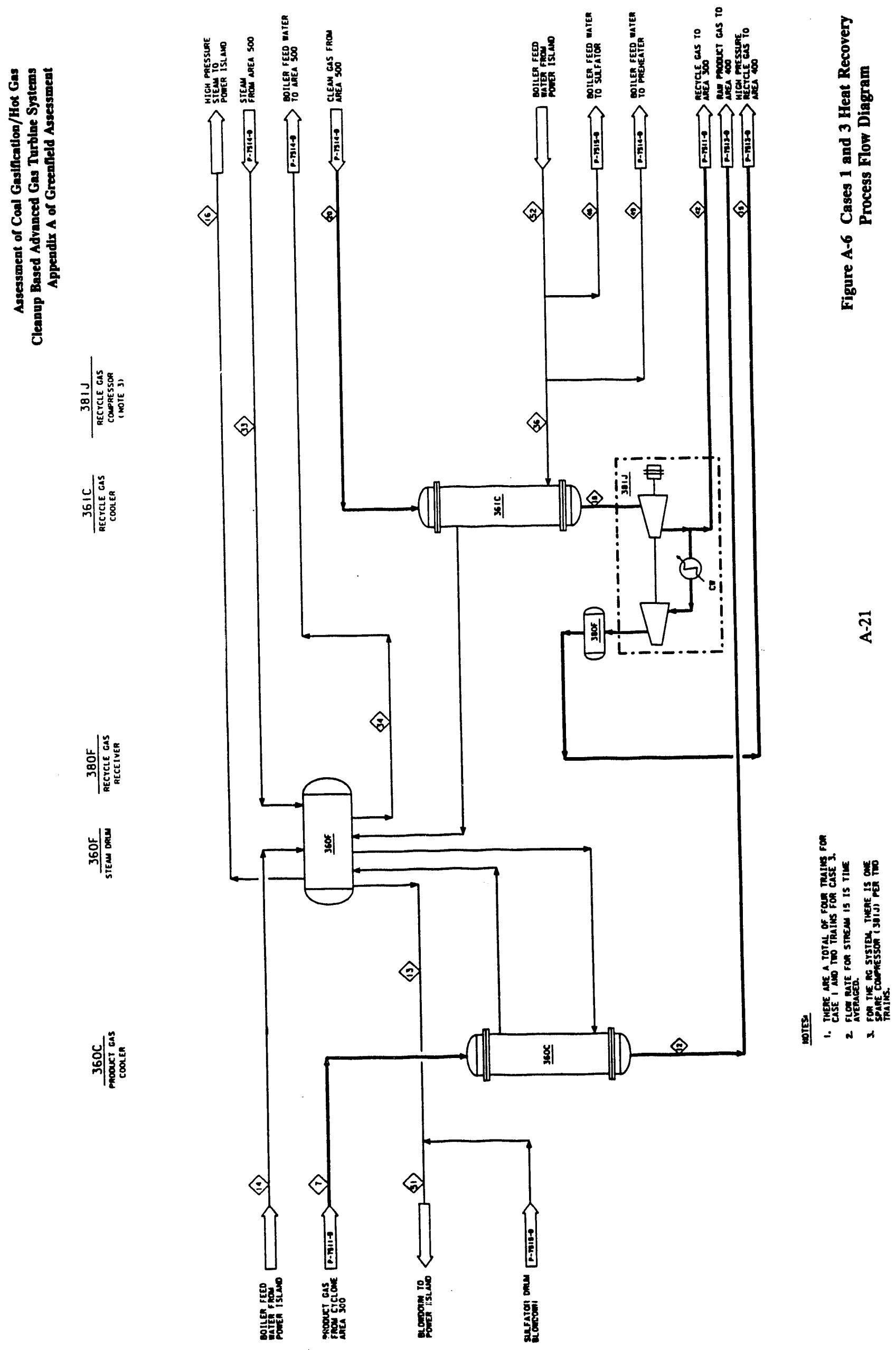




\section{A.2.1.5 Gas Conditioning}

This area consists of two subsystems, particulate removal, and the chloride guard beds. Figure A-7 is the process flow diagram of the gas conditioning system for Cases 1 and 3.

The cooled product gas $\left(1000^{\circ} \mathrm{F}\right)$ is passed through a non-recycle cyclone and a ceramic candle gas filter to remove all of the remaining particulates from the gas. The collected solids are transferred to a depressurization lockhopper where the pressure is reduced to atmospheric and from which the solids are sent through a water cooled conveyor to the sulfation area. Lockhopper pressurization is accomplished with gas from the highpressure recycle gas compressor. The chloride guard consists of two parallel fixed beds of calcined nahcolite sorbent. The beds have isolation valves to allow alternate operation for chloride capture. When a bed becomes loaded, as indicated by outlet gas analysis, it will be isolated; the sorbent will be replaced and the bed will be available for the next duty cycle.

\section{A.2.1.6 External Desulfurization}

Zinc ferrite was selected as the external bed sorbent for high-temperature coal gas desulfurization because of its effectiveness and capability for sulfur absorption combined with its regenerative characteristics. Figure A-8 is the process flow diagram of the external desulfurization system for Cases 1 and 3. The external desulfurization system consists of two zinc ferrite reactors and an exit-gas cooler. In a similar manner to the chloride guard drums, the two reactors are operated in a parallel arrangement.

Final product gas desulfurization is achieved in a fixed bed of zinc ferrite sorbent. As developed, the sorbent is a mixture of binders and modifiers and equimolar amounts of zinc oxide $(\mathrm{ZnO})$ and ferric oxide $\left(\mathrm{Fe}_{2} \mathrm{O}_{3}\right)$ with a combined chemical formula of $\mathrm{ZnFe}_{2} \mathrm{O}_{4}$. The sulfur capture mechanism is described by the following reactions:

$$
\begin{aligned}
& 6 \mathrm{ZnFe}_{2} \mathrm{O}_{4}+\mathrm{CO}+\mathrm{H}_{2} \rightarrow 6 \mathrm{ZnO}+4 \mathrm{Fe}_{3} \mathrm{O}_{4}+\mathrm{CO}_{2}+\mathrm{H}_{2} \mathrm{O} \\
& \mathrm{Fe}_{3} \mathrm{O}_{4}+3 \mathrm{H}_{2} \mathrm{~S}+\mathrm{H}_{2} \rightarrow 3 \mathrm{FeS}+4 \mathrm{H}_{2} \mathrm{O} \\
& \mathrm{ZnO}+\mathrm{H}_{2} \mathrm{~S} \rightarrow \mathrm{ZnS}+\mathrm{H}_{2} \mathrm{O}
\end{aligned}
$$

In addition, the water-gas shift reaction and the COS hydrolysis reaction are catalyzed by the iron oxide in the sorbent.

$$
\begin{aligned}
& \mathrm{CO}+\mathrm{H}_{2} \mathrm{O} \rightarrow \mathrm{CO}_{2}+\mathrm{H}_{2} \\
& \mathrm{COS}+\mathrm{H}_{2} \mathrm{O} \rightarrow \mathrm{H}_{2} \mathrm{~S}+\mathrm{CO}_{2}
\end{aligned}
$$

Reactions 2, 3, 4, and 5 are all exothermic, and a rise in temperature occurs as the gas passes through the bed. 
Assessment of Coal Gasification/Hot Gas

Cleanup Based Advanced Gas Turbine Systems

Appendix A of Greenfield Assessment

The level of $\mathrm{H}_{2} \mathrm{~S}$ in the reactor exit gas is determined by the equilibrium of hydrogen sulfide with zinc oxide (reaction 3 ) and is a function of temperature and steam concentration. As the hydrogen sulfide is reacted with the sorbent, COS hydrolysis (reaction 5) proceeds to extremely low levels of COS. At the design operating conditions, the reactor exit gas will contain less than $20 \mathrm{ppm}$ total sulfur.

As the gas passes through the bed, the sulfur is adsorbed by fresh sorbent, creating a moving front between the desulfurized gas and the feed gas. As this front approaches the end of the bed, and the sorbent reaches design loading, the gas flow is switched to the other reactor.

The zinc ferrite is regenerated by oxidation of the sulfides by the following reactions:

$$
\begin{aligned}
& 2 \mathrm{FeS}+7 / 2 \mathrm{O}_{2} \rightarrow \mathrm{Fe}_{2} \mathrm{O}_{3}+2 \mathrm{SO}_{2} \\
& \mathrm{ZnS}+3 / 2 \mathrm{O}_{2} \rightarrow \mathrm{ZnO}+\mathrm{SO}_{2}
\end{aligned}
$$

The oxidation reactions are highly exothermic and proceed as fast as oxygen is supplied. The progression of the moving front through the bed and the local bed temperature are controlled by the air and diluent steam flow. The regeneration exit gas is recycled to the gasifier, and the sulfur dioxide in the gas is captured by the limestone in the gasifier bed.

Regeneration of the first vessel begins with steam pressurization to a level above that in the gasifier. The flow of steam and air to the reactor is controlled to maintain the local bed temperature (at the oxidation front) below $1500^{\circ} \mathrm{F}$ to avoid sintering and destroying the sorbent. The minimum temperature range is $1100^{\circ} \mathrm{F}$ since lower temperatures will promote the formation of zinc sulfate.

Any zinc sulfate formed during the oxidative regeneration is converted to zinc oxide by a subsequent reductive regeneration with hydrogen and carbon monoxide (via recycled fuel gas) and is then ready for the next desulfurization cycle. The desulfurized product gas enters the exit-gas cooler where the temperature is controlled at the maximum fuelsupply valve temperature for supply to the gas turbine. High pressure saturated steam is produced at varied rates to effect the temperature control.

\section{A.2.1.7 Gasifier Solids Sulfation}

The mixture of spent (sulfided) limestone, ash, and fines is prepared for disposal in the fluidized-bed sulfator. This system is used to oxidize the calcium sulfide to calcium sulfate, a compound similar to gypsum, which can be readily disposed of in a dry landfill. The calcium sulfide oxidation reaction is highly exothermic and, at temperatures below $1600^{\circ} \mathrm{F}$, is accomplished with little formation of sulfur dioxide. Figure A-9 is the process flow diagram for the sulfation step in Cases 1 and 3. 


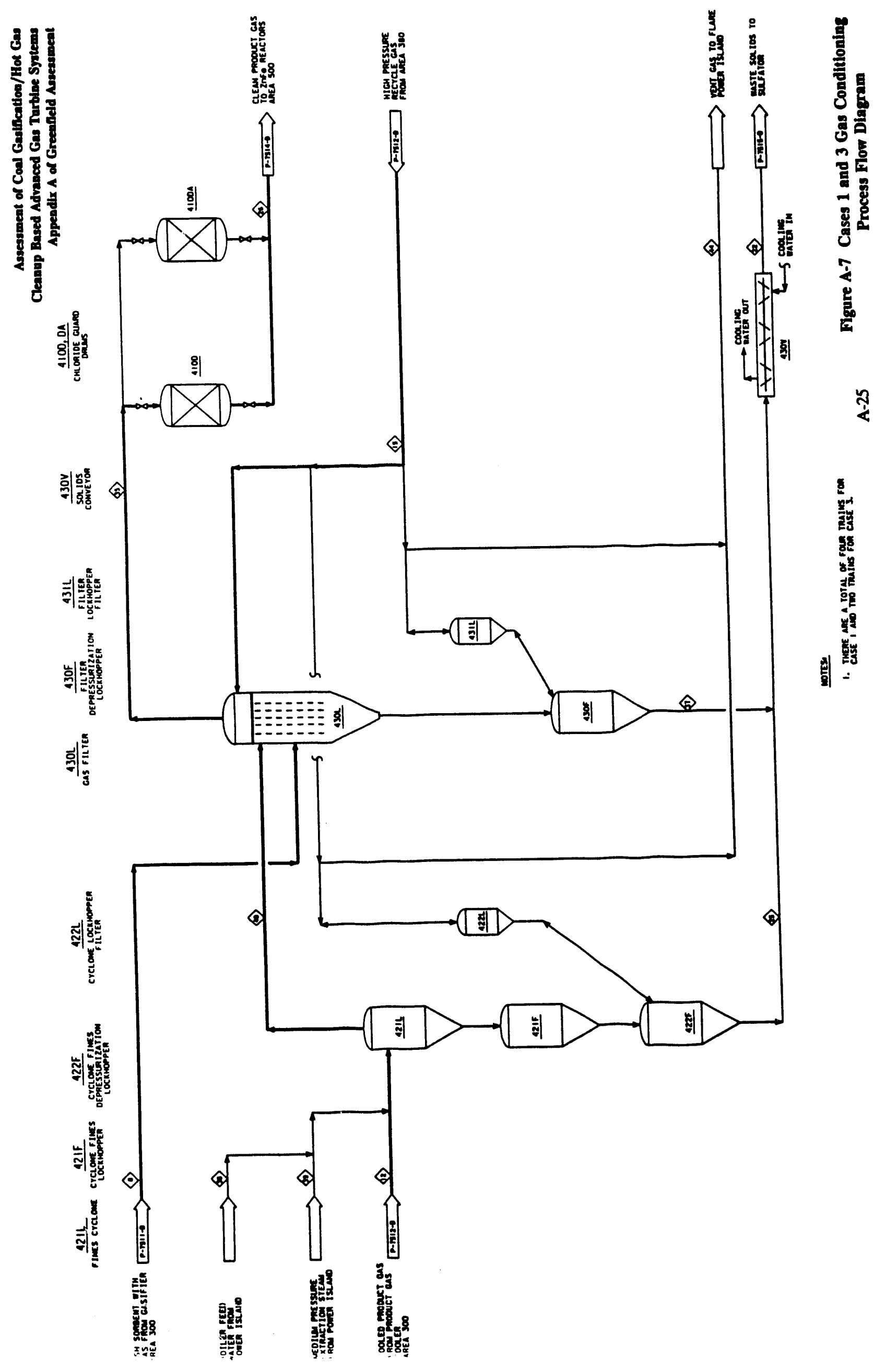




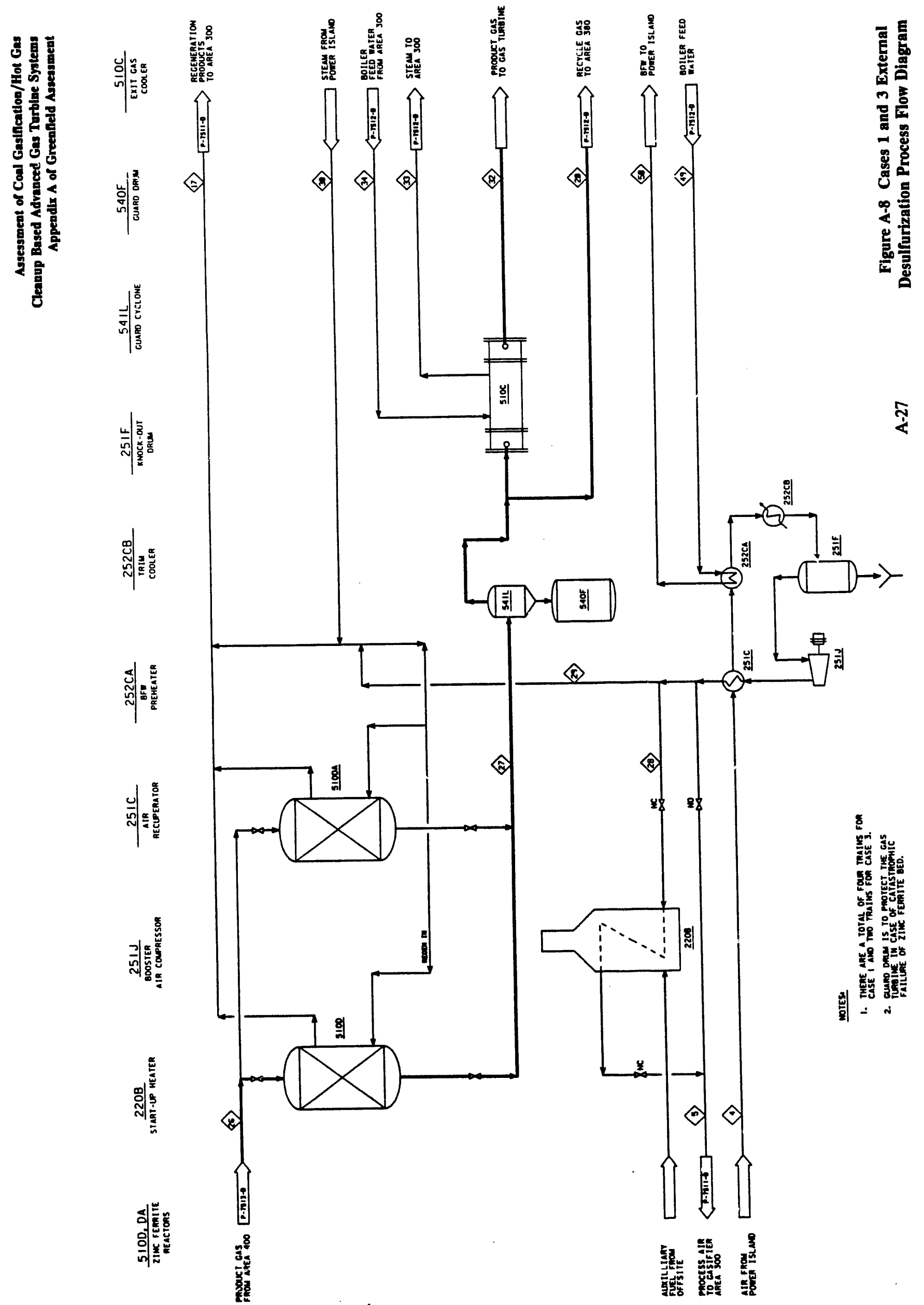



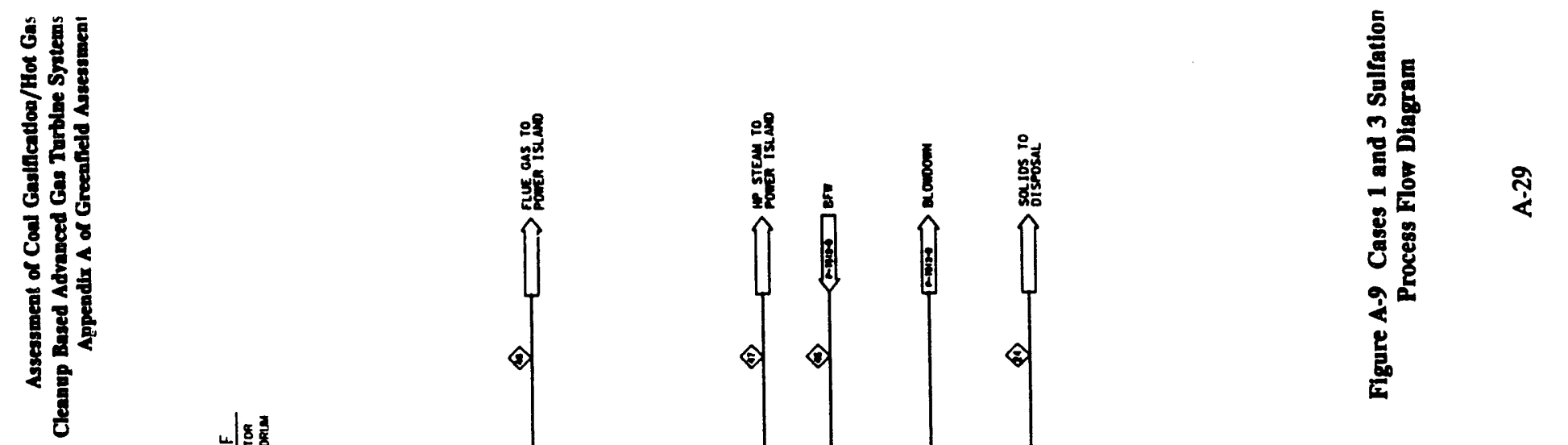

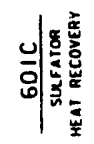

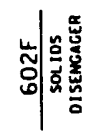

欲雚

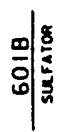

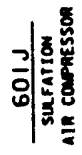

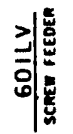

औ

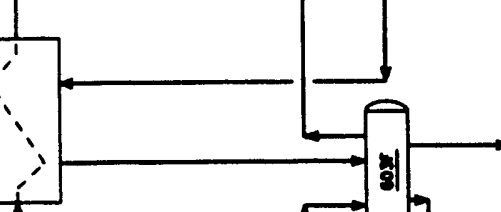

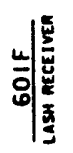
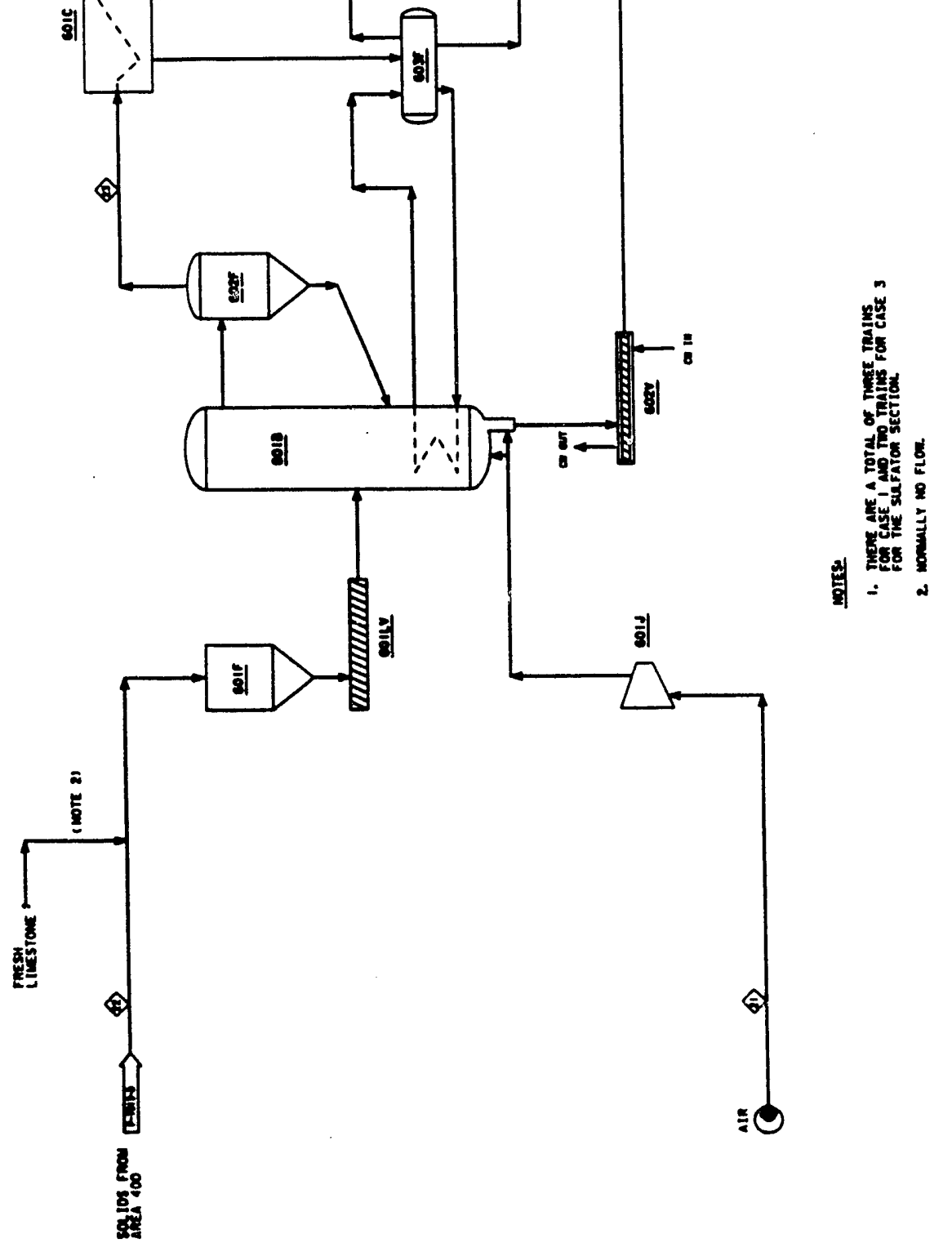
The sulfation combustor is a fluidized-bed system. Because of the highly exothermic reaction of calcium sulfide, the environment in the fluidized bed is favorable for the combustion of any residual carbon remaining in the char fines. The considerable quantity of heat generated in the combustor is used to produce high pressure saturated steam, thereby improving overall plant efficiency. The heat is recovered by in-bed exchanger tubes that keep the bed temperature less than $1600^{\circ} \mathrm{F}$ without the need for high excess air. The gas from the combustor is cooled by additional exchanger surface before it is routed to the coal preparation section of the plant for coal drying.

Feed to the sulfation combustor from the surge bin is controlled by a screw feeder included with the fluidized-bed system. Discharge solids from the bed are cooled in a screw conveyor/cooler and discharged for eventual disposal.

\section{A.2.1.8 Gas Turbine System}

The advanced-design GE MS7001F combustion turbine serves as the heart of the power island design for the IGCC cases. The GE MS7001F is a new combustion turbine design which has been introduced by General Electric, with the first unit having been recently installed and placed into commercial operation at Virginia Power's Chesterfield station in mid-1990. The GE MS7001F is a high-firing-temperature design which employs a turbine inlet temperature of approximately $2300^{\circ} \mathrm{F}$.

The configuration of the power island for Case 1 is shown in Figure A-10. The power island configuration for Case 3 is shown in Figure A-11.

Inlet air to the combustion turbine is taken into the compressor and compressed to about 200 psi and $730^{\circ} \mathrm{F}$. Some compressor discharge air is bled from the primary air stream and sent to the gasification island where it is used in the production of the coal gas. The fraction of the total compressor discharge air flow that is bled to the gasification process

- is approximately 15 percent. The remaining compressor discharge air goes to the combustor of the GE MS7001F where it mixes with the coal gas which then ignites. The hot gases from the combustor discharge pass through the power turbine section of the combustion turbine, producing power which is used to drive the compressor and an electric generator.

\section{A.2.1.9 HRSG System}

The HRSG takes the exhaust flow from the combustion turbine and uses the heat to produce steam for both power production in the steam turbine and for process steam use in the gasification island. One HRSG is used for each combustion turbine. The HRSG configuration is heavily integrated with the gasification island in order to achieve maximum steam production for the overall plant.

Two pressure levels are used in the steam system, one for the production of high pressure (HP) steam to the turbine throttle and the other for intermediate pressure (IP) steam production to supplement the steam flow to the reheat section of the steam 


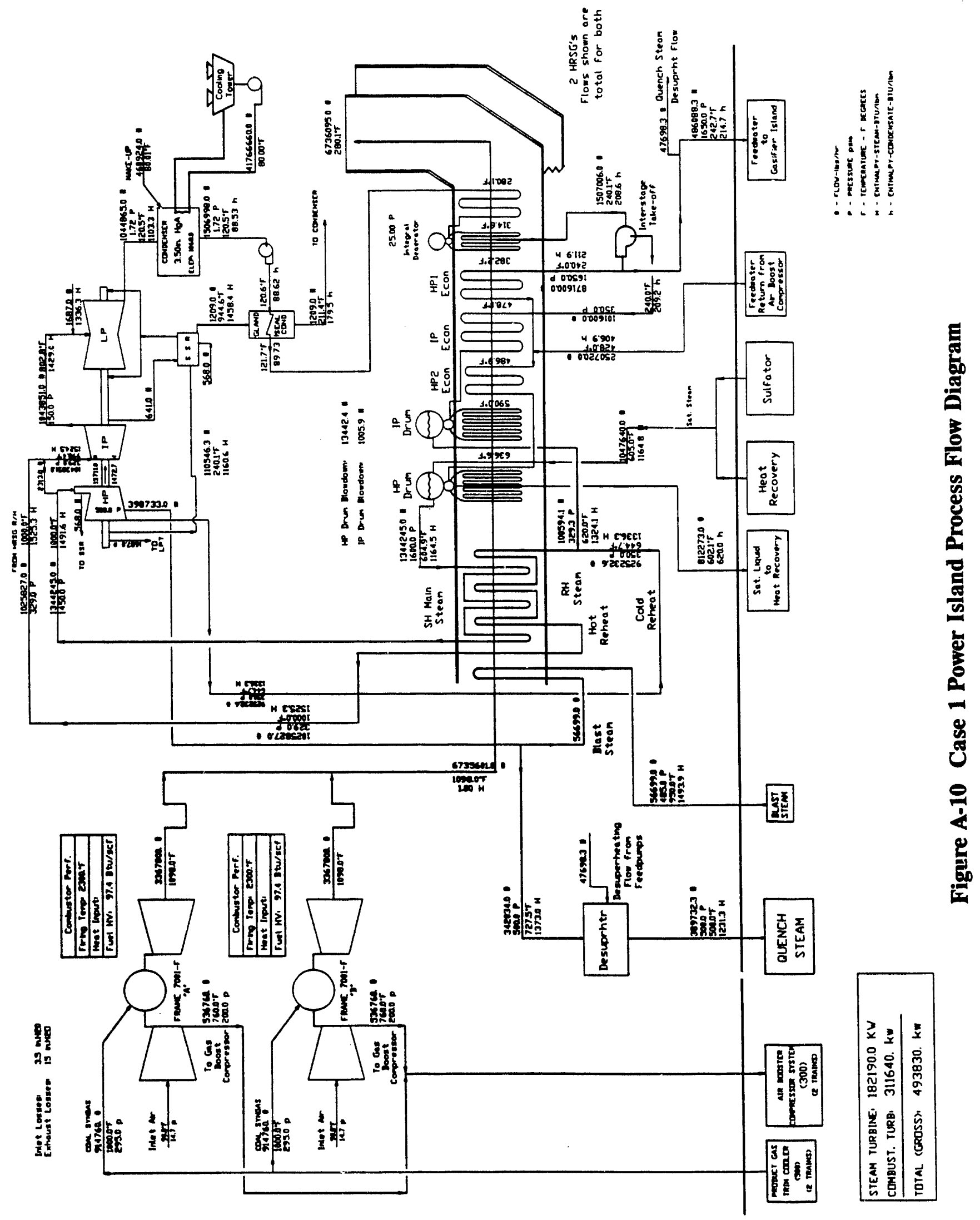




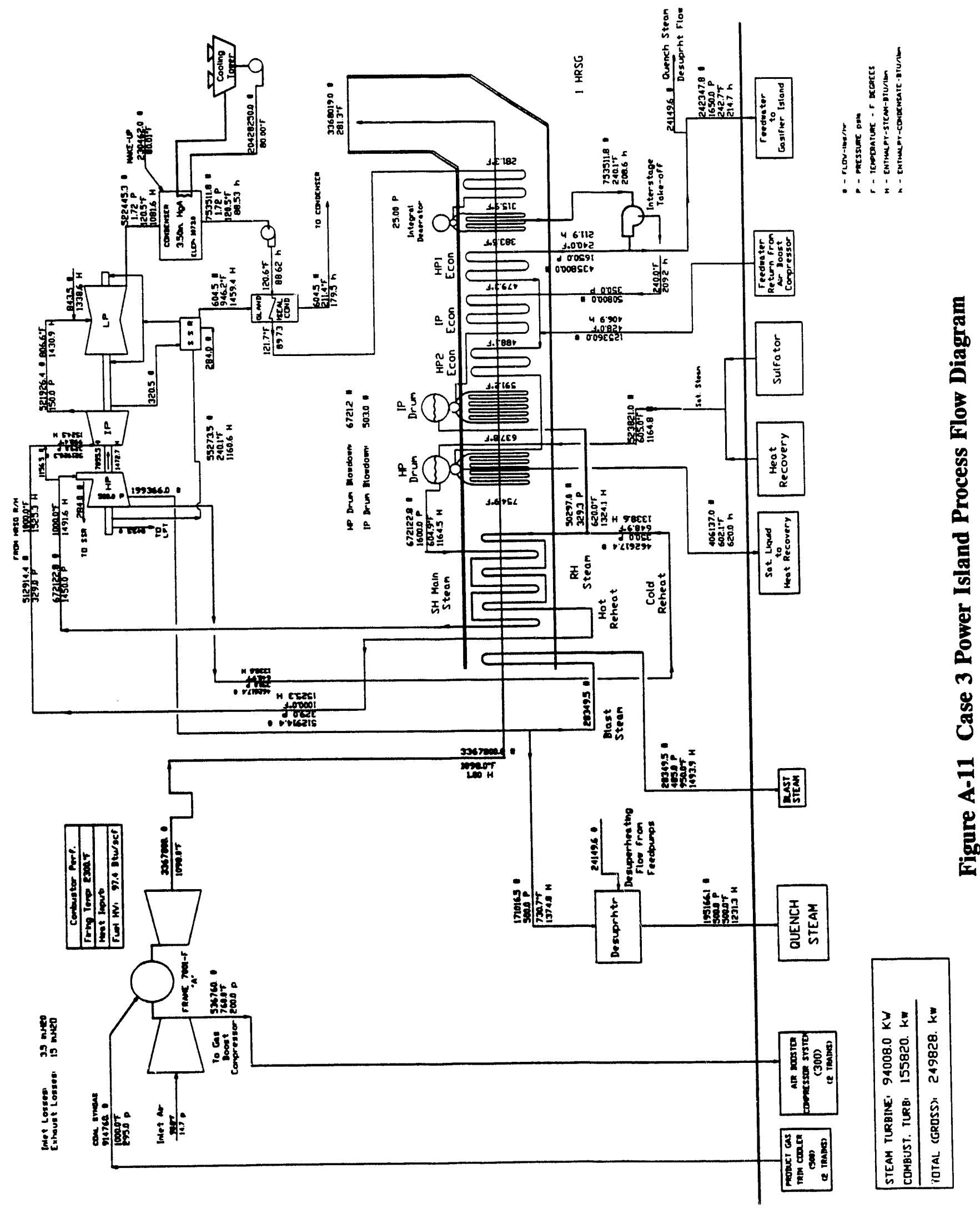


Assessment of Coal Gasification/Hot Gas

Cleanup Based Advanced Gas Turbine Systems

Appendix A of Greenfield Assessment

turbine. An additional superheater section is also used to superheat the blast steam that is used in the gasification process. Figures A-10 and A-11 show the basic configurations of the HR.SGs for Cases 1 and 3.

The following heat transfer sections are utilized in the HRSG:

- HP steam superheater

- IP steam reheater

- Blast steam superheater

- HP evaporator

- IP evaporator

- HP economizer 2

- IP economizer

- HP economizer 1

- Integral deaerator

- Feedwater heating coil

The integral deaerator and feedwater heating coil are located within the HRSG to maximize the heat recovered from the exhaust gas stream and, therefore, maximize tire power production of the steam turbine by eliminating extractions for deaerating steam and feedwater heating.

\section{A.2.1.10 Steam Turbine System}

A reheat steam turbine is the main component of the steam turbine system. The HP steam from the HRSG enters the HP turbine section of the turbine at 1450 psig and $1000^{\circ} \mathrm{F}$ and exhausts to the HRSG reheater. The steam is reheated to $1000^{\circ} \mathrm{F}$ and enters the IP turbine section. After passing through the IP/LP section of the turbine, the steam exhausts to a condenser. An extraction port in the HP turbine is used to provide steam at approximately 500 psi for both quench steam and blast steam use in the gasifier island. There are no other extractions except typical shaft leakage and sealing steam flows.

The condensate from the condenser is sent to the HRSG feedwater heating coil and HRSG integral deaerator via condensate pumps. Boiler feedpumps send the feedwater from the deaerator to the HRSG economizers and gasifier island. A circulating water system using a mechanical draft cooling tower and circulating water pumps is used for condenser cooling water. The condenser design pressure is $3.5 \mathrm{in}$. $\mathrm{HgA}$ at the $90^{\circ} \mathrm{F}$ ambient-design point with a $90^{\circ} \mathrm{F}$-cooling water temperature.

\section{A.2.1.11 Ash Handling and Disposal}

The ash handling system transports the ash from the discharge of the screw conveyors in the sulfator area to an onsite landfill for disposal. Figure A-12 is the process flow diagram for the ash handling system for Case 1. The configuration of the system for 


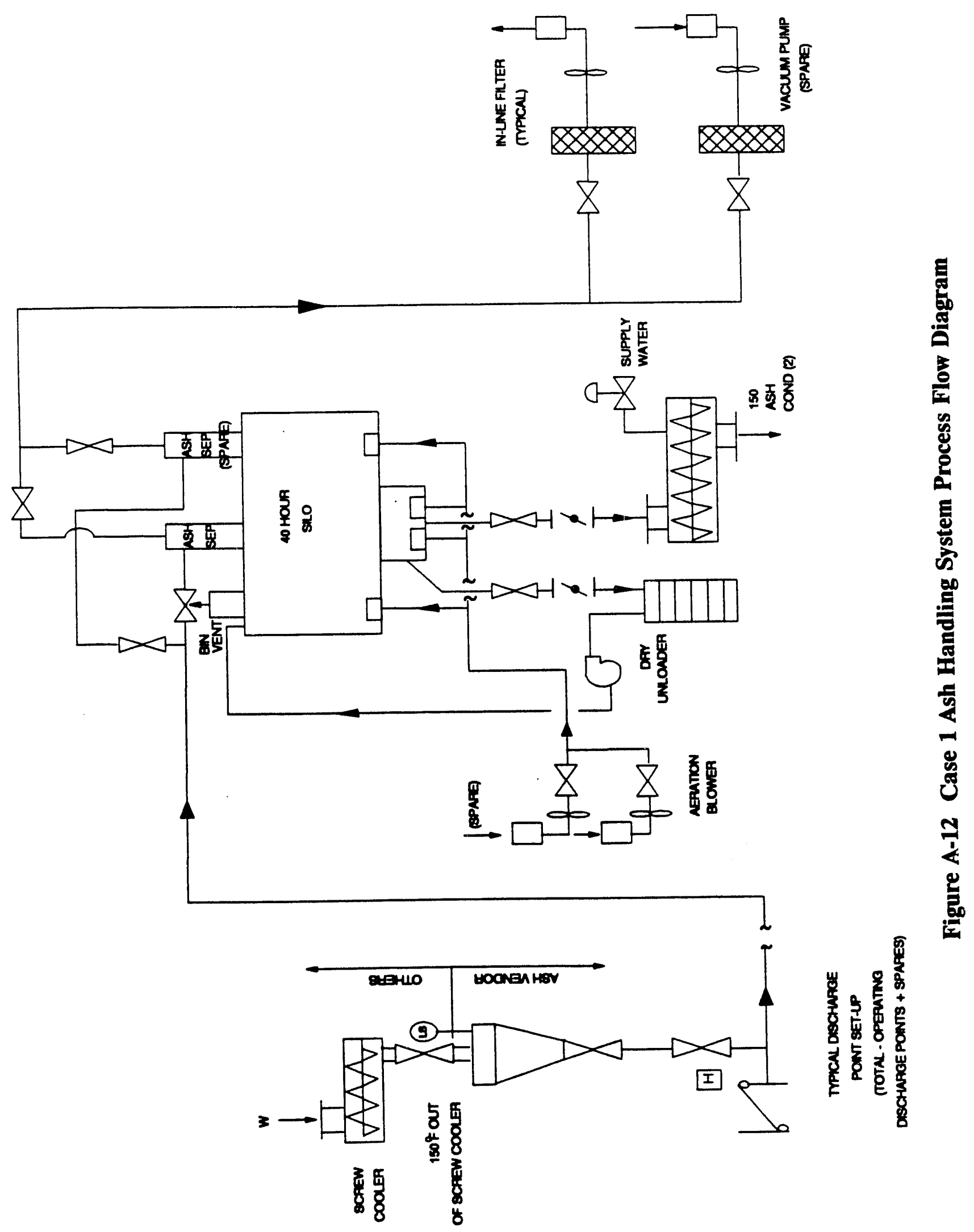


Case 3 is similar to that of Case 1 . The conveying system is a dilute-phase vacuum type with surge bins at the discharge of each screw conveyor to allow for up to one hour of storage. The ash is conveyed to a 40-hour storage silo with mechanical lobe type blowers acting as vacuum pumps. The 40-hour ash silo allows the landfill to be operated only one shift per day and also allows for ash storage when the landfill cannot be operated due to inclement weather. The silo has a flat bottom with aeration to assist in discharge of ash. The discharge of the silo is equipped with a conditioner that adds the optimum amount of water prior to discharge to a dump truck. A dry loader allowing discharge to a tanker truck is also provided, although the normal mode of operation would be to use dump trucks. The conditioned ash is transported to an onsite landfill by dump truck.

\section{A.2.1.12 General Facilities}

The general facilities include all site preparation and improvements, roads and rail facilities, buildings, fuel oil storage and handling, and fire protection. The cooling water systems, raw water supply, potable and utility water, sewers, and effluent water treating were also included in the general facilities. Electrical and control systems were considered part of the general facilities and included a central computer system, plant and instrument air, electrical switchyard and distribution, lighting, and communications. Miscellaneous items such as painting and interconnection of piping between area battery limits were also included in the genera! facilities.

\section{A.2.2 Plant Layouts}

Equipment design parameters were developed based on the results of the thermal analysis and the specific structural and material requirements for the various pieces of equipment. The detailed equipment descriptions are provided in this appendix. Based on the functions, physical features, and interconnections of the equipment, conceptual plant layouts were developed for each IGCC plant.

The IGCC plant is located on the Plant Wansley site in an area reasonably convenient to the existing coal pile, switchyard, and transmission distribution system. The one constraint placed on location was that the IGCC plant not interfere with the areas set aside for future Plant Wansley Units 3 and 4, which are currently designated to be pulverized coal-fired units. This constraint could be eliminated in the future if the IGCC technology replaces pulverized coal units as the technology of choice for baseload power generation at Plant Wansley.

Figures A-13 and A-14 show the overall site plan for the IGCC plants of Cases 1 and 3. The overall arrangement can be divided into four distinct and separate areas: 


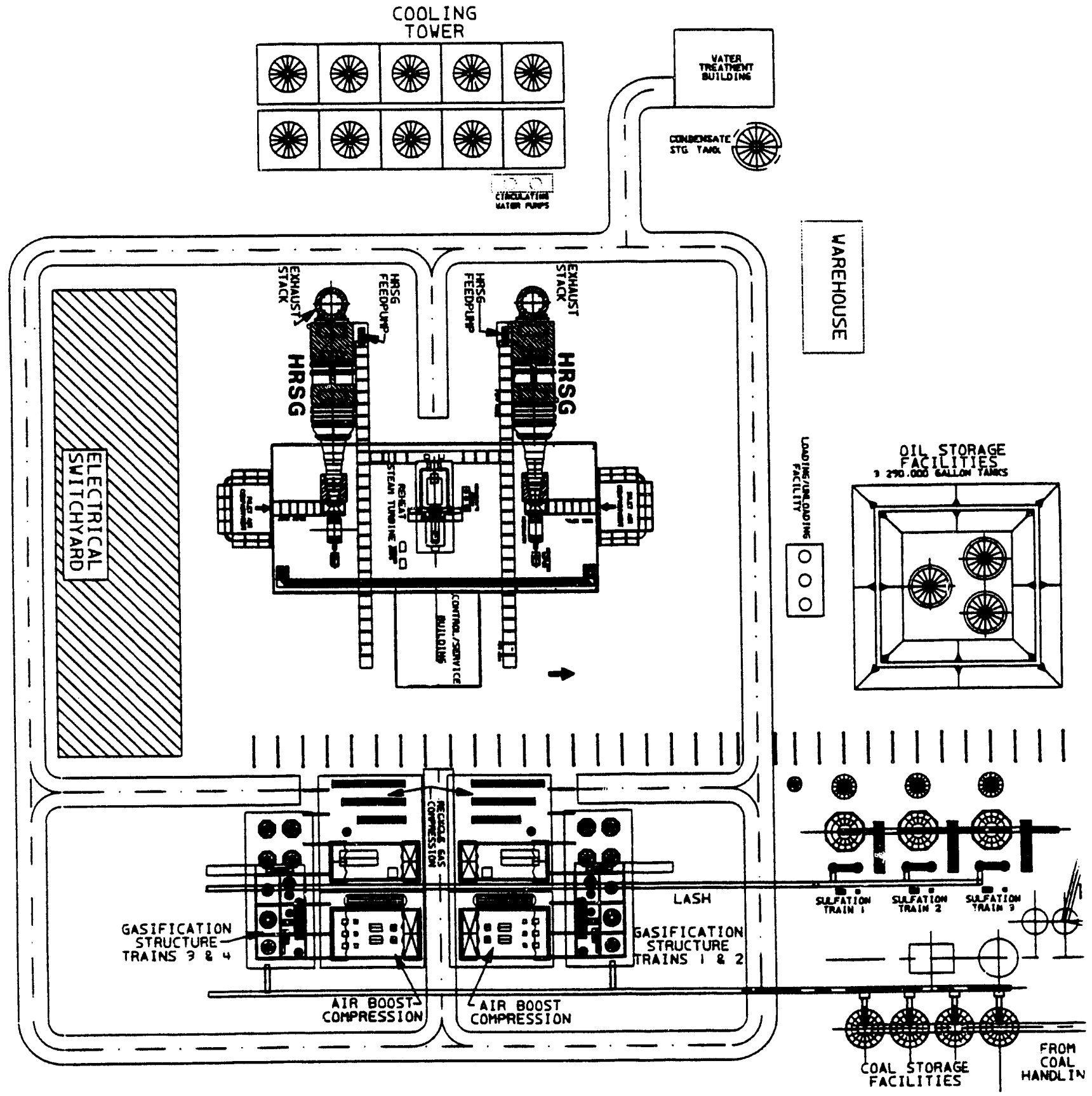

Figure A-13 Case 1 Overall Site Plan 
Assessment of Coal Gasification/Hot Gas

Cleanup Based Advanced Gas Turbine Systems

Appendix A of Greenfield Assessment

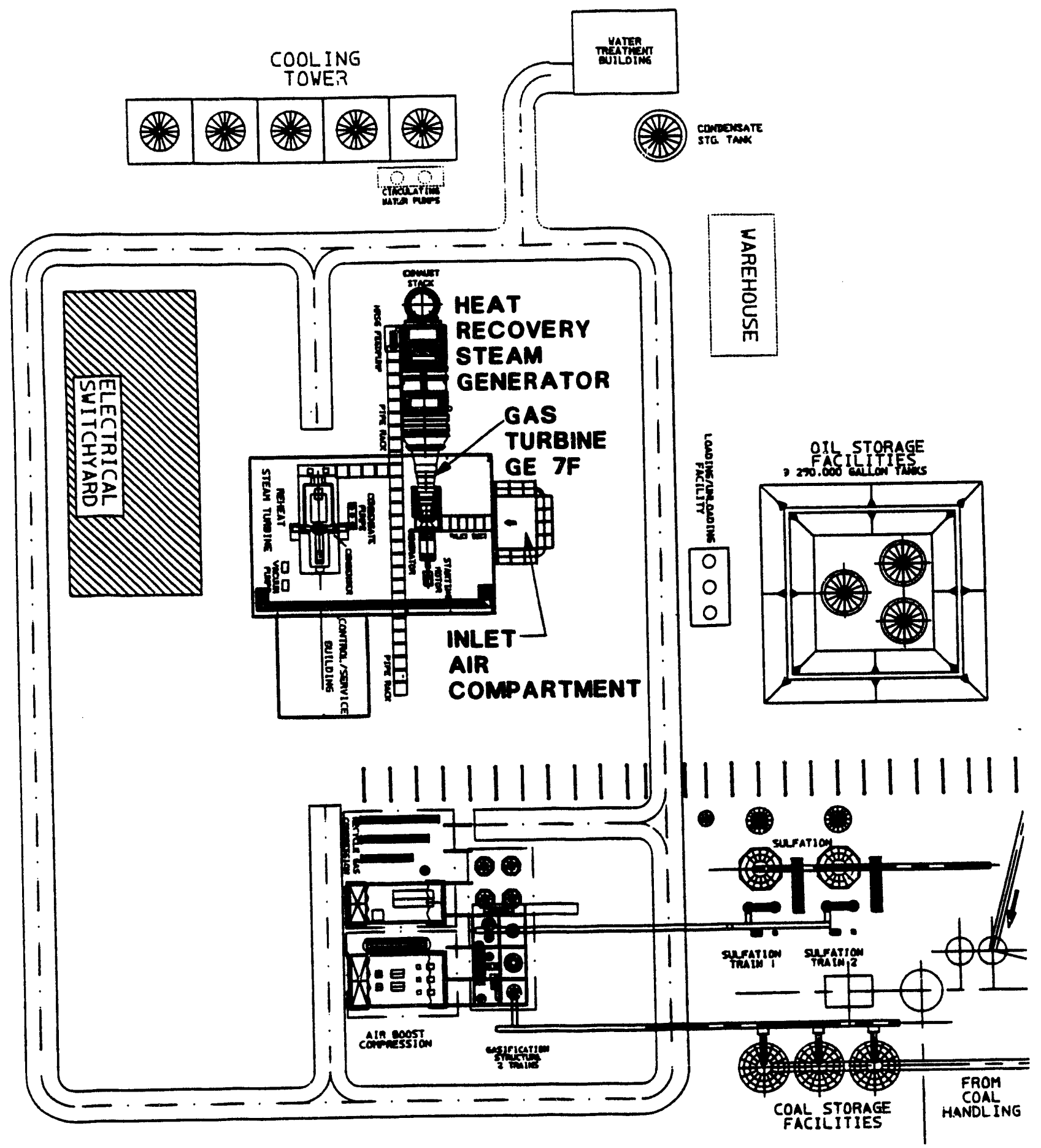

Figure A-14 Case 3 Overall Site Plan 
- Power Island

- Gasifier Island

- Coal and Limestone Bulk Storage

- Electrical Switchyard

A conceptual plot plan and elevation and isometric views of the gasification train for Cases 1 and 3 are given in Figures A-15 and A-16.

The general approach for developing the site layout was to make the most efficient use of the existing facilities (particularly the coal unloading facilities) while totaling specific considerations for a variety of factors such as environmental constraints regarding HRSG stack height, personnel safety, and maintenance access to equipment.

The power island layout is arranged such that the HRSG stacks are located at a sufficient distance from the gasifier island to minimize the height of the stacks as determined by environmental constraints. The combustion turbines and steam turbine are housed in a powerhouse which has an overhead crane for equipment maintenance. The combustion turbine inlet air filters are located on the sides of the powerhouse in order to minimize the effects of fugitive dust and emissions from the gasifier island and to minimize the effects of the inlet air ducting on crane access. Due to the location of the hot gas piping and requirements for maintenance access at the east end of the building (near the generators), the electrical switchyard cannot be located at the east end of the power island, but must be located instead at the south end. This requires slightly longer lengths of high voltage cabling but maximizes employee safety and equipment accessibility. The cooling tower is located at a point which would minimize the effect of the cooling tower plume on nearby structures (prevailing winds are from the west/northwest) and minimize the circulating water system piping requirements. The power island equipment arrangement was developed using actual vendor equipment drawings for the major equipment including the HRSG, steam turbine, combustion turbine, and supporting pumps.

The layout of the coal and limestone handling facilities was developed in a manner to make the optimum use of the existing coal unloading facilities and to minimize the lengths of conveyors needed for coal and limestone transport to the gasifier island. 


\section{A.3 400-MW IGCC WITH TRANSPORT GASIFIER (Case 6)}

\section{A.3.1 Process Discussion}

The IGCC plant for Case 6 is sized at nominally $400 \mathrm{MW}$ and utilizes the transport gasifier concept currently under development by MWK. As described subsequently, the transport gasifier is a circulating-bed gasifier which uses pulverized coal and limestone. It is expected that the small particle size of the limestone for the transport gasifier will increase the sulfur capture within the gasifier sufficiently to eliminate the zinc ferrite polishing step that was required with the KRW gasifiers. Also, the coal throughput is higher for the transport gasifier, which reduces the number of gasifiers and gas processing trains from four as in Case 1 down to two in Case 6. Solid waste from each gasifier is fed to a pressurized sulfator for calcium sulfide oxidation, with the pressurized flue gas from the sulfator sent to the power island for additional power generating capacity. The power island configuration for Case 6 is similar to that of Case 1 with two gas turbines, two HRSGs, and a single steam turbine.

\section{A.3.1.1 Overall Arrangement}

The block flow process diagram for Case 6 is shown in Figure A-17 with corresponding process stream flows listed in Table A-3. Coal and limestone is sized and dried prior to being fed to the transport gasifier. Limestone is dried with an oil-fired heater, as in Case 1. The coal is dried using a slipstream of hot flue gas taken from the HRSG. Gasification air, as well as air for the sulfator, is provided by two air booster compressors (one train per gas turbine) which boost the pressure of the air extracted from the gas turbines.

The product gas from the transport gasifier is cooled in a heat recovery step to produce high pressure steam before entering the high temperature ceramic filters for removal of particulates from the product gas. The clean product gas from the gas filters is then sent directly to the combustion turbine.

The ash from the gasifier and fines from the gas filtration step are sent to a pressurized transport sulfator where calcium sulfide is oxidized to calcium sulfate. The pressurized flue gas from the sulfator goes to a gas filtration step before being sent to the combustion turbine. The solid waste from the sulfator is cooled in a heat recovery step to produce steam, followed by a final cooling step prior to disposal. The cleaned product gas from the gasifier and the pressurized flue gas from the sulfator are both utilized in the combustion turbine to produce power. The flue gas from each combustion turbine is sent to a separate HRSG to produce steam for the gas island and power generation in a single steam turbine as in Case 1. 

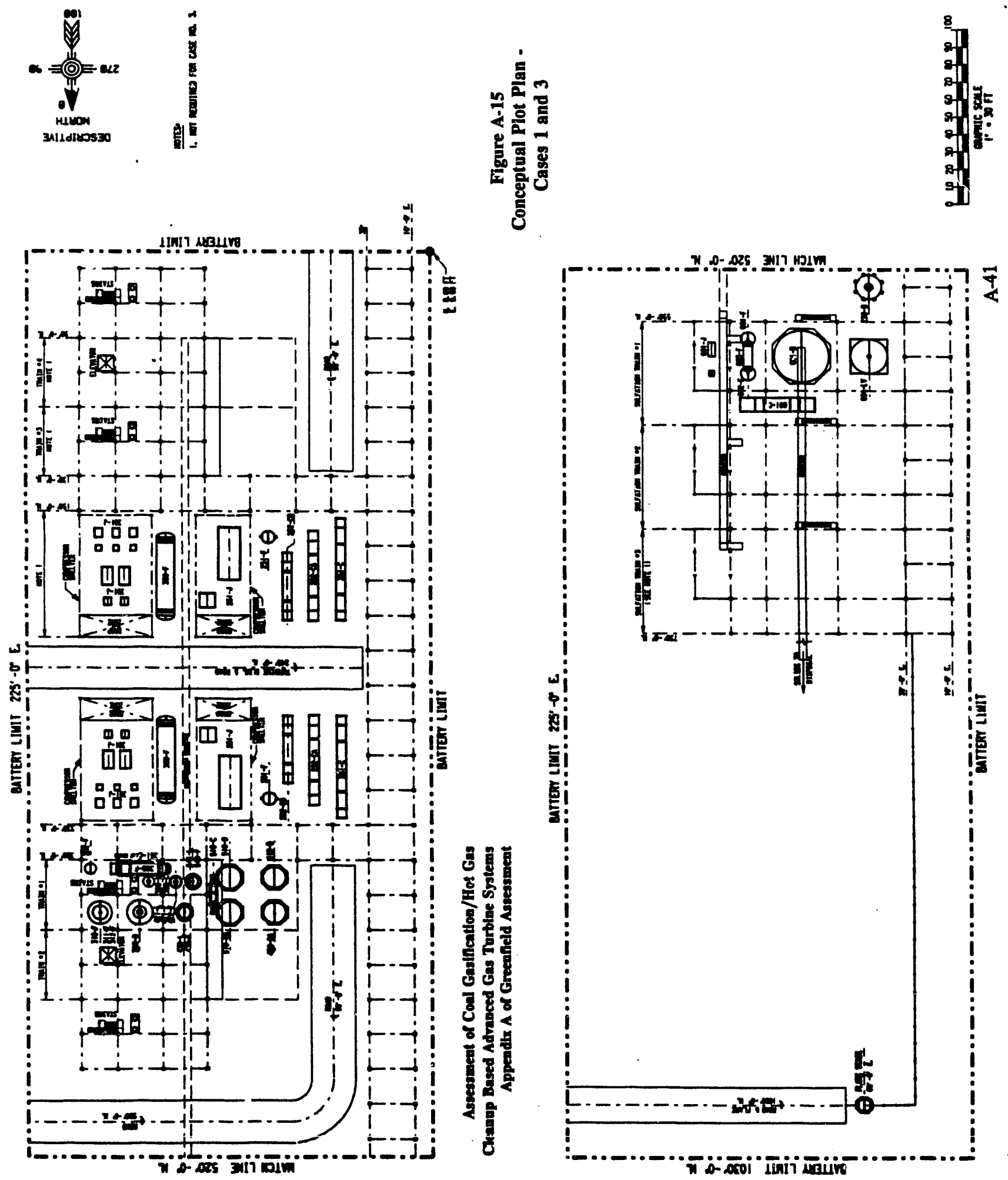


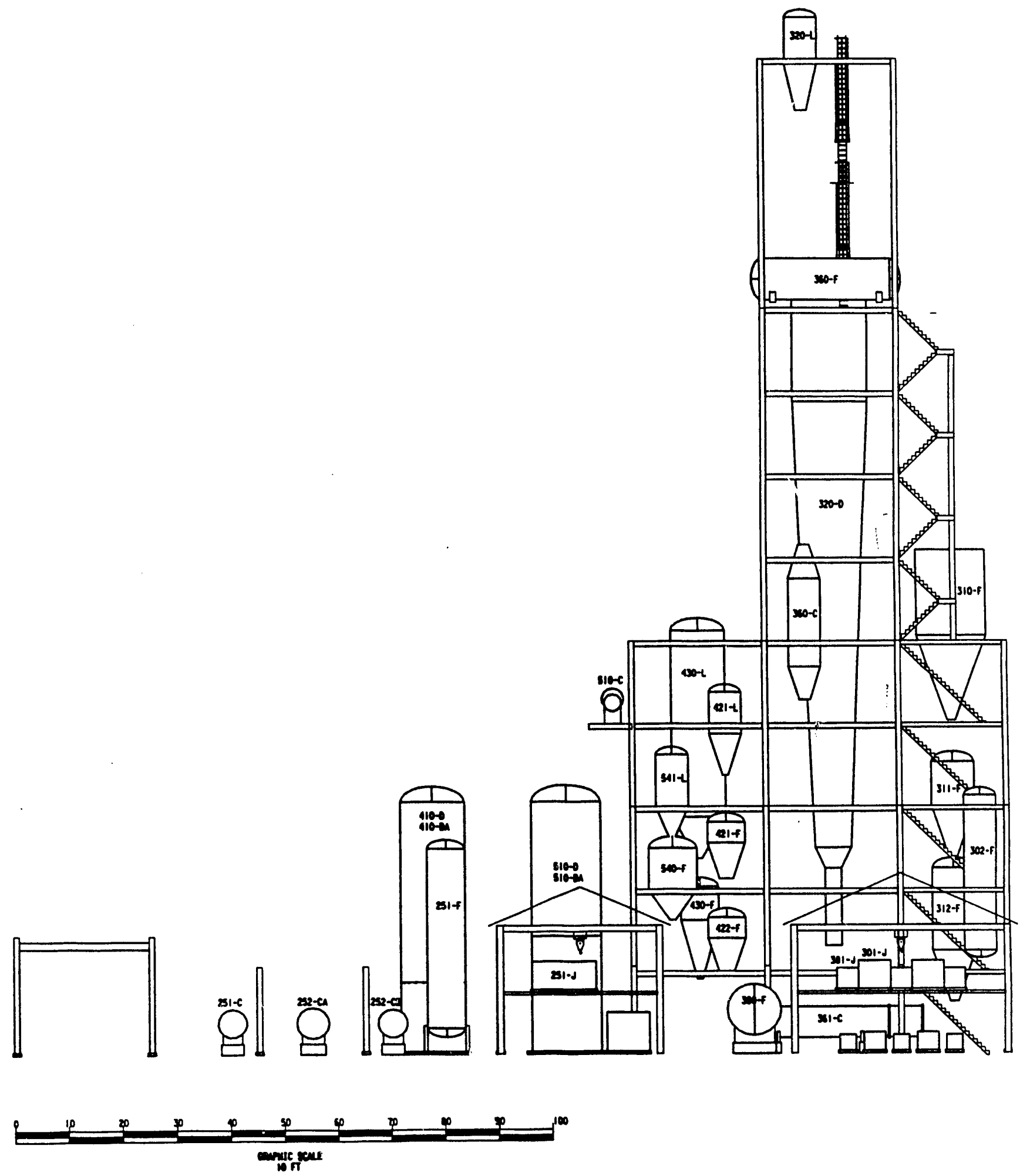

Figure A-16 (Sheet 1 of 2) Gasification Train Layout, Isometric View - Cases 1 and 3 
Assessment of Coal Gasification/Hot Gas

Cleanup Based Advanced Gas Turbine Systems

Appendix A of Greenfield Assessment

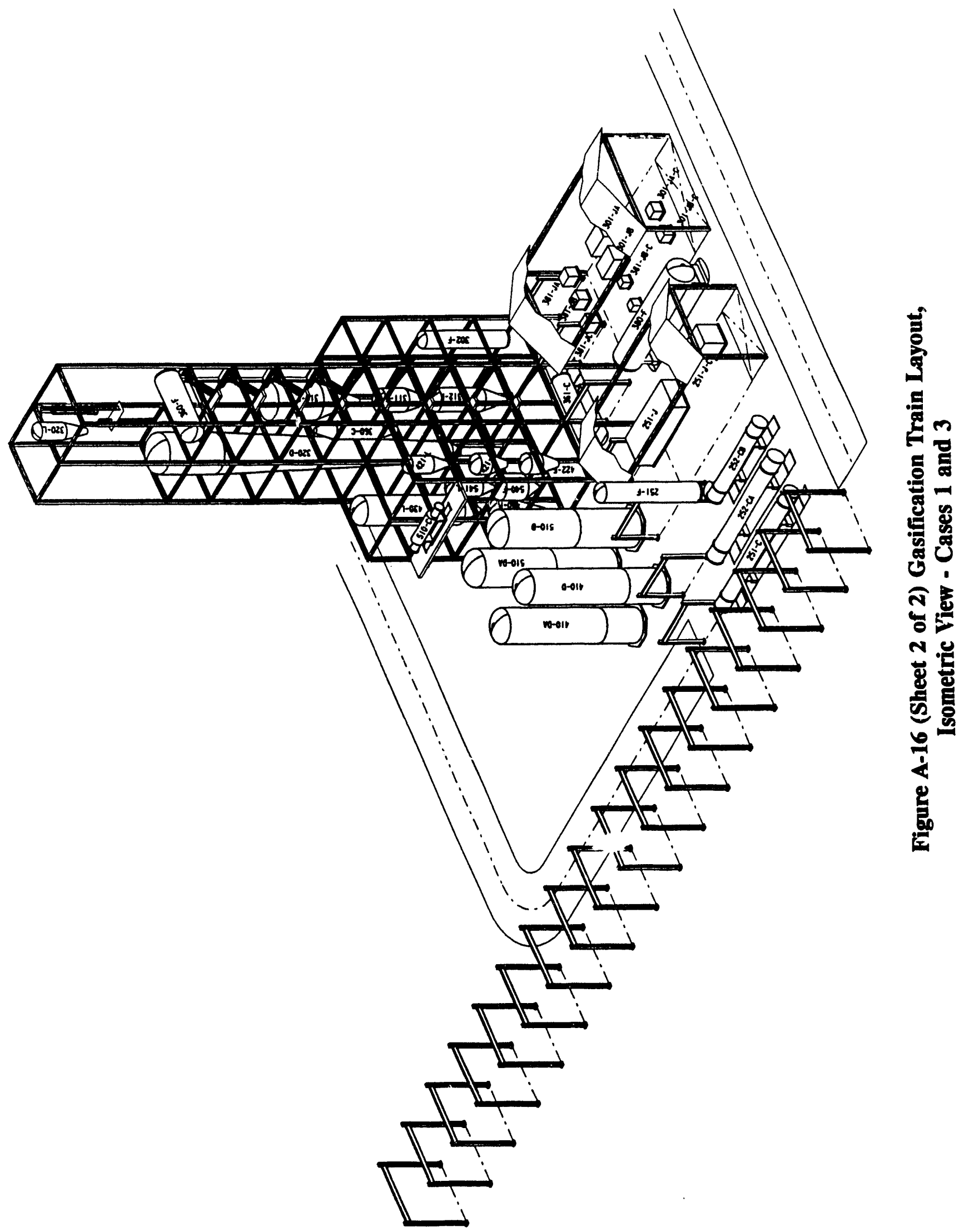


Assessment of Coal Gasification/Hot Gas

Cleanup Based Advanced Gas Turbine Systems

Appendix A of Greenfield Assessment

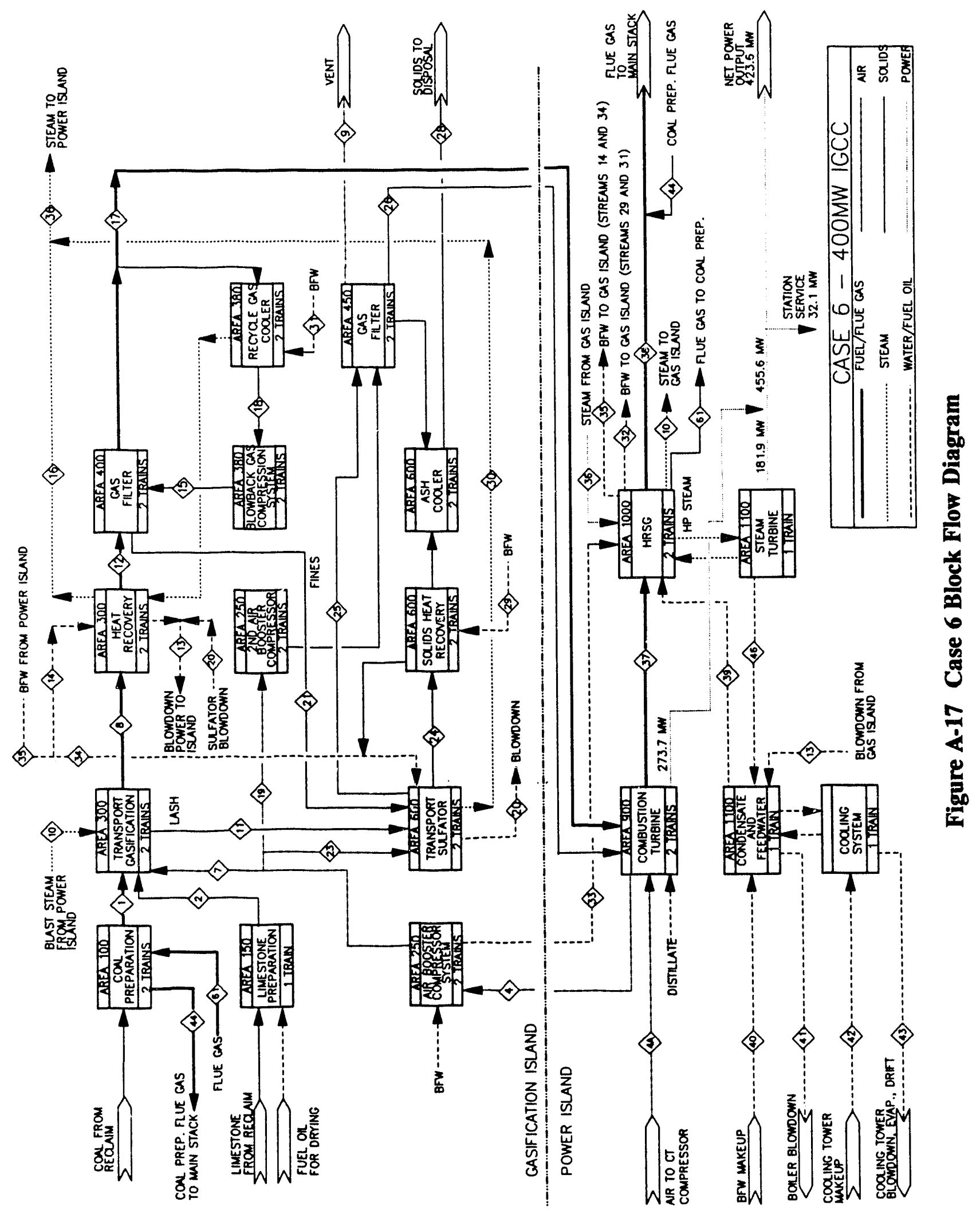




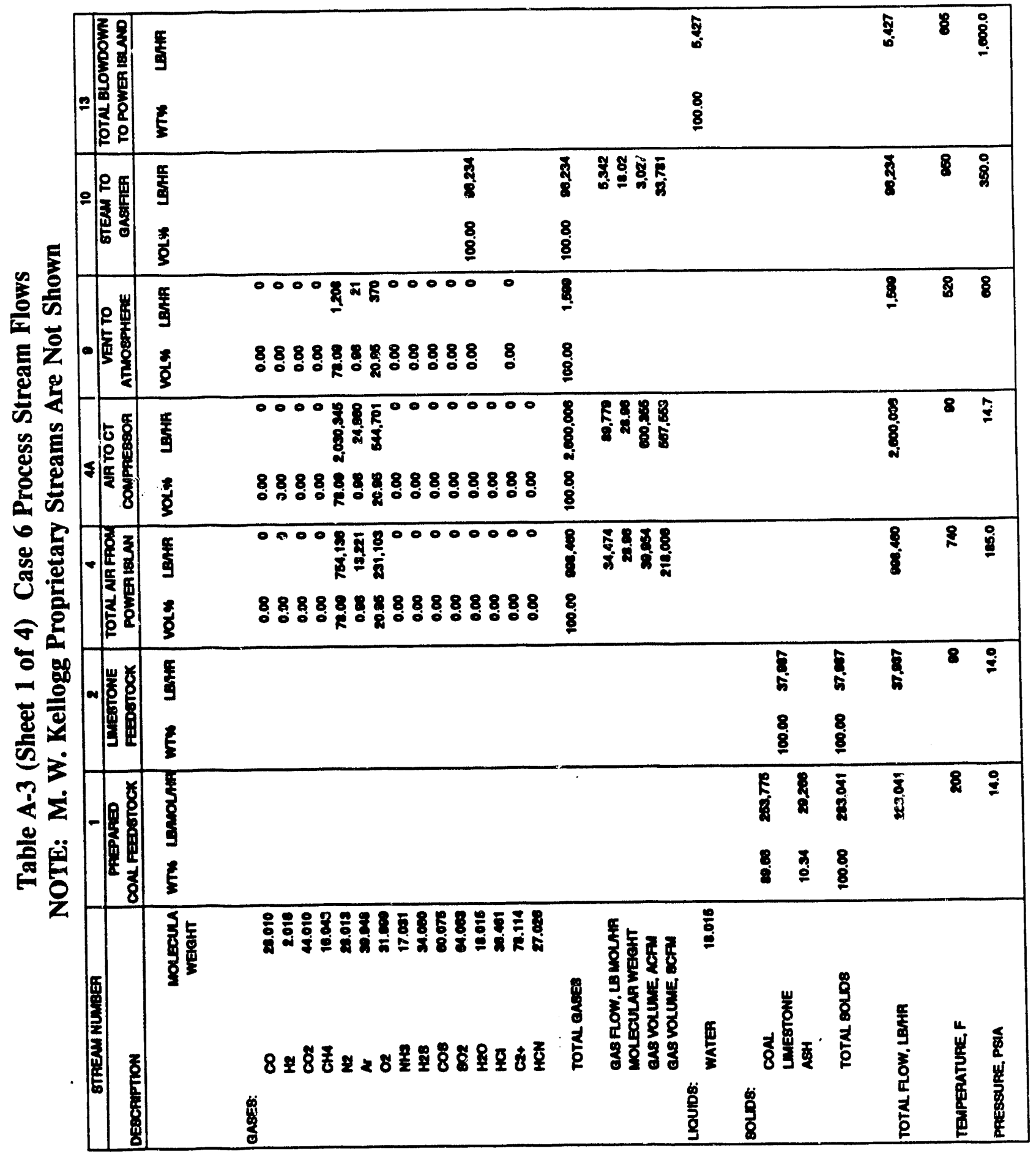




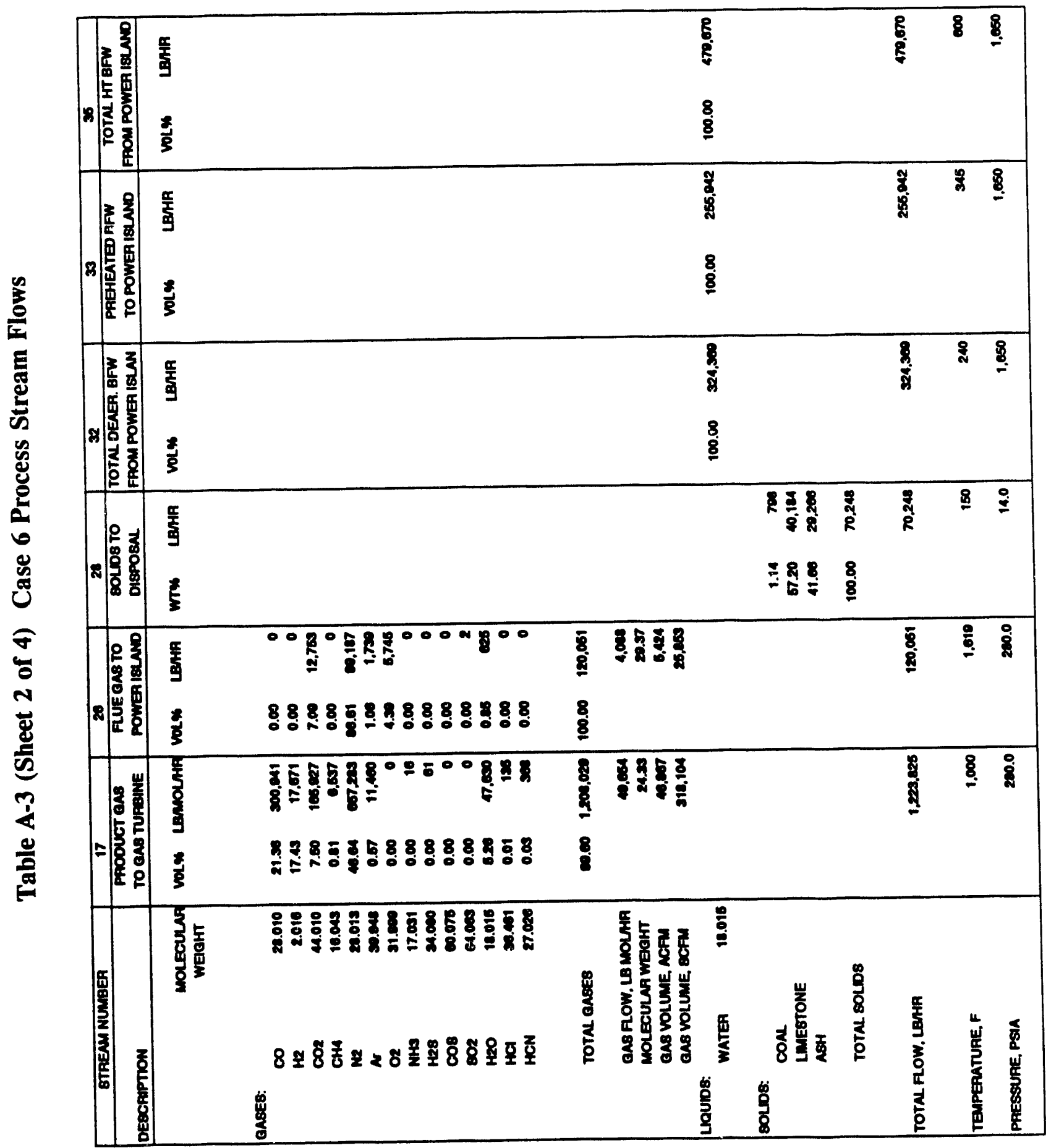


Assessment of Coal Gasification/Hot Gas

Cleanup Based Advanced Gas Turbine Systems

Appendix A of Greenfield Assessment

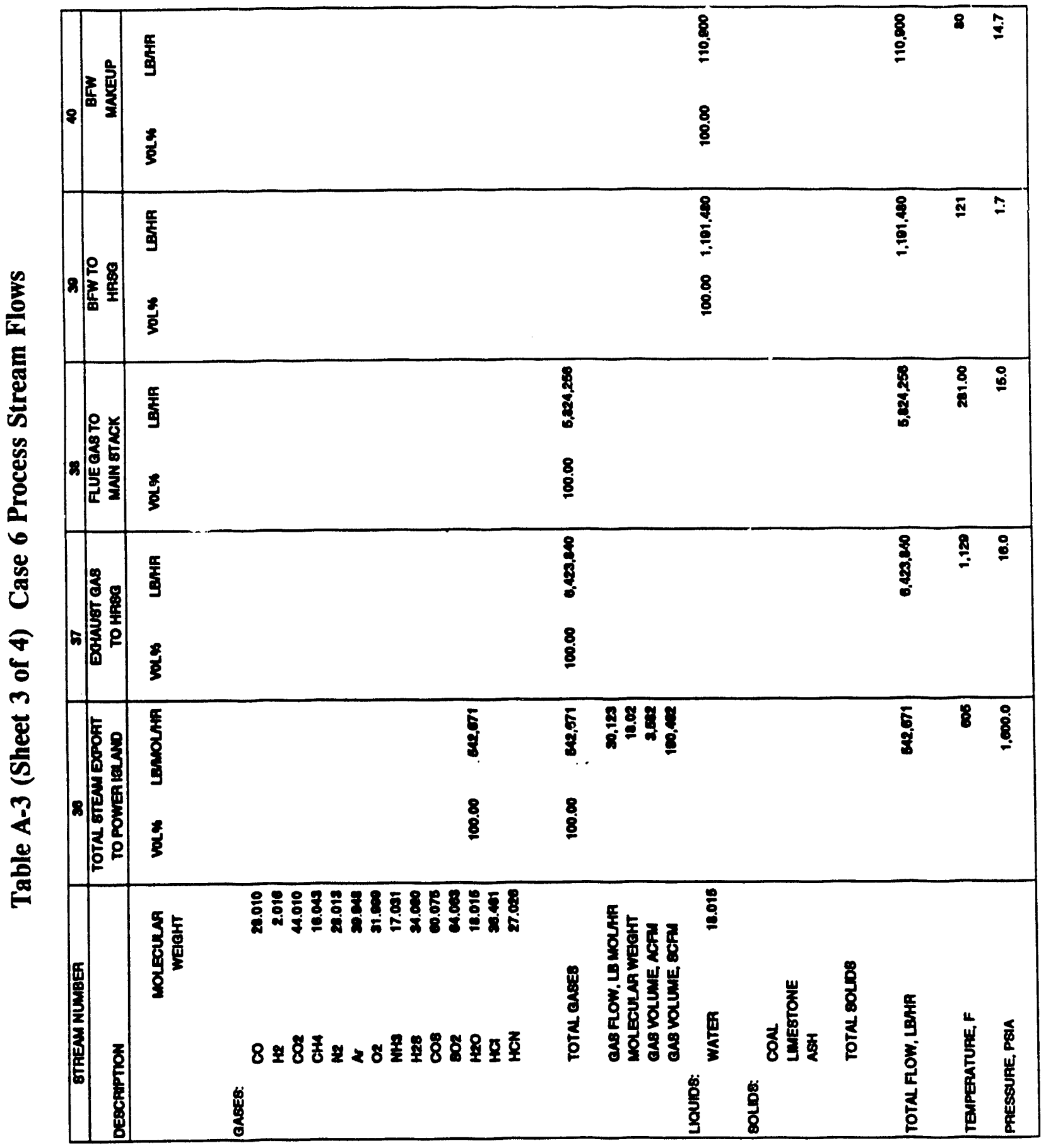




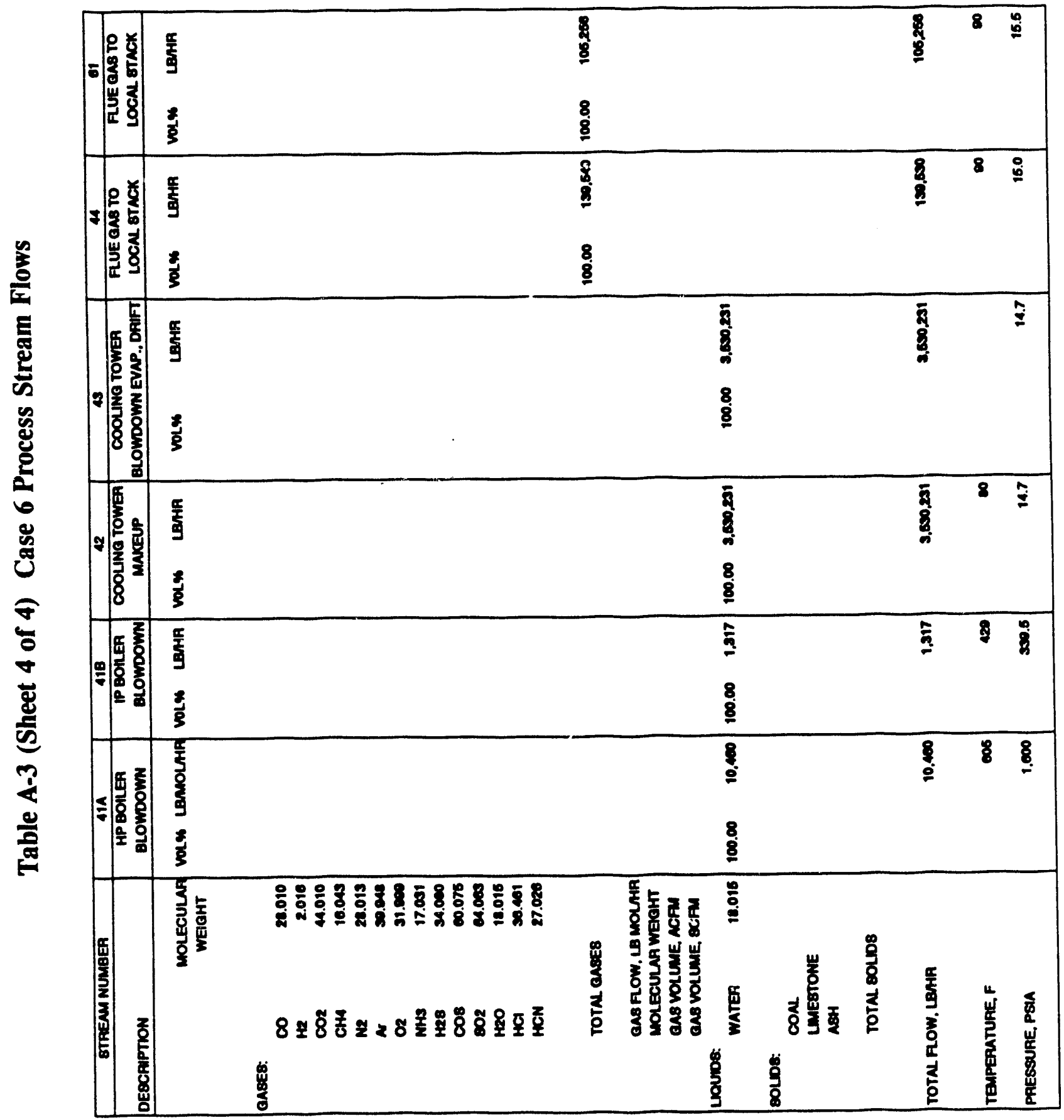


Assessment of Coal Gasification/Hot Gas

Cleanup Based Advanced Gas Turbine Systems

Appendix A of Greenfield Assessment

\section{A.3.1.2 Coal and Limestone Receiving, Handling, and Preparation}

The configuration of the system for Case 6 is the same as for Case 1 except for the differences listed below:

- The grind size is smaller (pulverized product versus minus $1 / 4$-inch).

- The coal silos and pulverizers have been relocated to a site closer to the HRSGs to make the use of hot flue gas cost effective.

- Case 6 has five storage silos and five pulverizers (four operating and one spare pulverizer).

- Coal and limestone are conveyed into the gasifier separately.

- Nitrogen is used to convey the coal to the gasification area with a closed-loop pneumatic conveying system; nitrogen is required for inerting due to the small coal particle size.

- Some equipment capacities are different because of the differences in coal feed rate.

Figure A-18 is the process flow diagram for the coal and limestone preparation area.

In this case, the pulverizers were relocated to allow hot flue gas from the HRSGs to be used for coal drying, since sulfator flue gas is not available. A sulfator is present in Case 6, but the sulfator is adjacent to the gasifier and is pressurized to the same pressure as the gasifier. Since the flue gas from the sulfator is under pressure, it is sent to the combustion turbines. Also, nitrogen is not available for drying since an air separation plant is not needed for Case 6.

With air blown gasification using fine coal particles, coal drying becomes a very important design consideration since nitrogen is not available for coal drying and inerting. Typically, coal handling and preparation are located far from the combined cycle equipment to minimize the exposure of the equipment to coal dust. However, the economics are much more favorable using HRSG flue gas for coal drying as compared to oil fired heaters. Heat losses from the drying gas would be too great if the flue gas were transported from the HRSG to the gasifier side of the plant and then back to the stacks at the HRSG. Therefore, the coal preparation area for Case 6 has been moved to a location nearer the HRSGs.

The layout of the limestone preparation system is the same as for Case 1, except that a dedicated pneumatic system is used to convey the limestone from the 24-hour storage silo to a surge bin in the gasification area. 


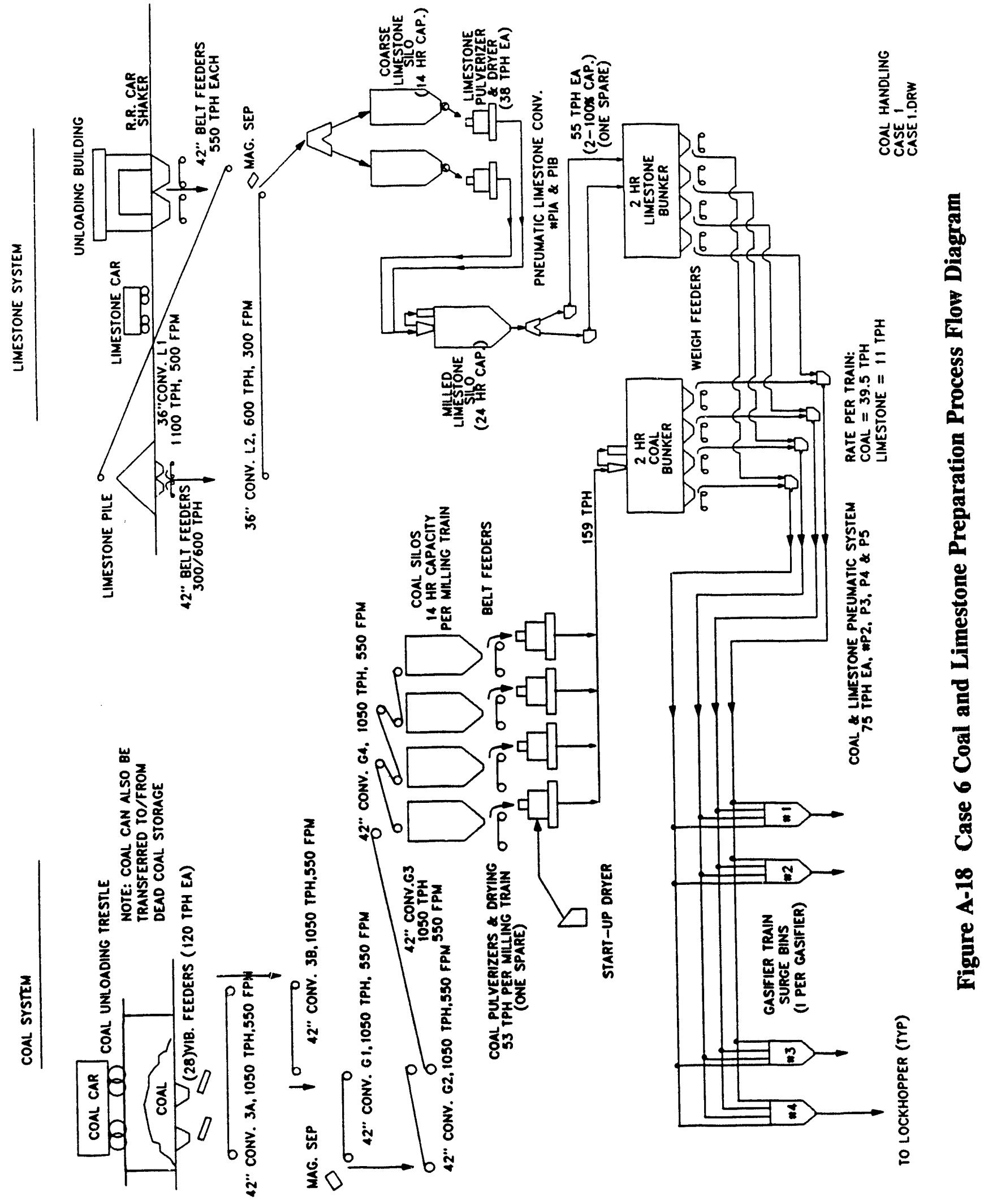


Assessment of Coal Gasification/Hot Gas

Cleanup Based Advanced Gas Turbine Systems

Appendix A of Greenfield Assessment

\section{A.3.1.3 Air Compression and Supply}

This area is comprised of two subsystems: the boost air compression system and the lockhopper air compression system. The subsystems are described separately below and are shown schematically in Figure A-19.

\section{Boost Air Compression (Area 250)}

The boost air compression system provides the air necessary for the operation of the gasifier and the sulfator. Air for this system is obtained by extraction from the compressor section of the gas turbine located in the combined cycle power plant.

Air from the gas turbine compressor discharge is first cooled in the air recuperator. This exchanger simultaneously cools the relatively high-temperature air obtained from the gas turbine and heats the compressor discharge air prior to delivery to the gasifier and the sulfator. After the initial air cooling is accomplished, a BFW preheater and a trim cooler are employed to cool the air to a lower temperature for more efficient air compression. A small stream of air from the booster compressor discharge is bypassed around the recuperator for compression and utilization as sulfator filter blowback gas. A knockout drum is provided at the compressor suction to remove condensed moisture.

\section{Lockhopper Air Compression}

A separate air compressor is provided for lockhopper pressurization. The compressor is sized for the average flow required by the lockhoppers. To accommodate the relatively large periodic flows to the lockhoppers, a surge vessel is provided. There are three lockhopper air compression trains.

\section{A.3.1.4 Coal Gasification and Recycle Gas Compression}

This area consists of three functional subsystems: coal/sorbent pressurization, gasification, and heat recovery. These subsystems are described below and illustrated in Figure A-19, the gasification process flow diagram.

\section{Coal/Sorbent Pressurization}

A conventional lockhopper system is used to pressurize the coal and limestone feed to the gasifier. Unlike the KRW gasifier, coal and limestone are not mixed together but are pressurized and fed separately to the gasifier to ensure that the desired calcium to sulfur ratio is maintained in the short-contact-time transport gasifier. The pressurization trains for coal and limestone are functionally identical, although the coal train is much bigger than the limestone train. The following description of the coal pressurization train is also applicable to the limestone pressurization train. 


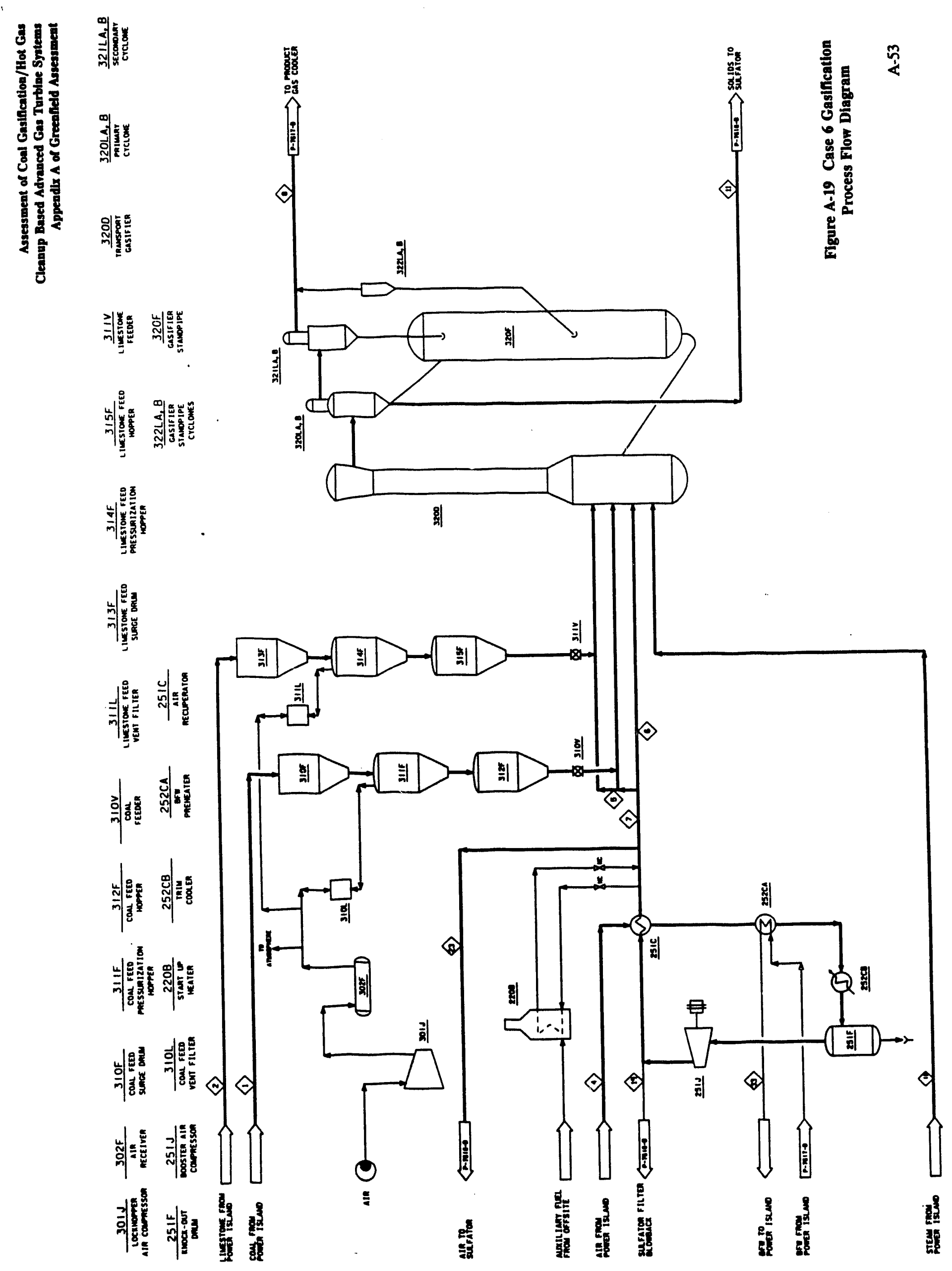


Coal is delivered to the coal feed surge drum from the coal preparation area. The coal feed pressurization hopper periodically receives coal from the feed surge drum. Two valves are used between the vessels: the upper valve to initiate or stop solids flow and the lower to provide a gas tight seal. After a batch of coal is received, the coal feed pressurization hopper is pressurized with high pressure air. When the pressure in the coal feed pressurization hopper is equalized with that of the coal feed hopper, a valve located between these two vessels is opened to dump coal into the feed hopper. After the coal feed pressurization hopper is emptied, the valve is closed and the hopper is vented to atmospheric pressure to repeat the cycle. A vent filter is installed on the pressurizing/venting line to essentially eliminate particulate emissions when the coal feed pressurization hopper is vented. The hopper is pressurized through this same filter to provide an automatic backflushing of the filter media.

The coal feed hopper is operated at constant pressure sufficient to permit starwheel feed rnetering and pneumatic conveying of the coal to the gasifier by an air stream. The relative proportions of coal and limestone fed to the gasifier will be established by setpoint adjustments based on sulfur content of the gasifier product gas obtained from an online sulfur analyzer.

\section{Gasification}

The coal is gasified in a pressurized transport gasifier. The gasifier is a refractory-linedriser-type reactor. The transport gasifier is made up of two sections, namely the mixing zone; where the recycled hot solids, coal and limestone, steam, and air are introduced; and the riser section. The mixing zone provides adequate residence time for gas and solid mixing. The fresh coal devolatilizes and the volatiles burn consuming all the supplied oxygen. Also, part of the sulfur in the coal is released here, and gasification and sulfur capture begin in this zone. The riser section provides additional residence time for coal gasification and sulfur capture.

Coal and limestone are fed continuously to the transport gasifier by their respective rotary feeders. Steam required for the gasification reactions is imported from the power island and fed to the gasifier. Air from the air recuperator is admitted at the bottom of the gasifier. All fresh feeds are mixed with recycle char from the gasifier standpipe in a mixing zone in the bottom of the gasifier where the devolatilization, gasification, and combustion reactions begin. The temperature in this zone is controlled to achieve desired carbon conversion.

A very high carbon conversion is predicted for the transport gasifier, with the remaining char being burned in the transport sulfator for nearly 100-percent carbon conversion. Conversion in the gasifier is controlled by maintaining the proper solids circulation rate in the system, thus controlling the gasifier bed density. The limestone sorbent completely calcines in the gasifier and removes most of the $\mathrm{H}_{2} \mathrm{~S}$ produced by the gasification reactions. 
The gas/solids mixture flows up through the gasifier at relatively high velocity and exits the reactor at the top. The heavily solids-laden fuel gas enters the primary cyclones where bulk-solids removal occurs and then flows through secondary cyclones, which remove most of the remaining solids. Two primary and two secondary cyclones are provided for each gasifier. Collected solids from the cyclones flow by gravity to the gasifier standpipe. This vessel provides the pressure head needed to maintain adequate solids circulation. The vessel is aerated with a small amount of recycle gas, and standpipe cyclones, two per standpipe, are provided to remove any entrained particles before the recycle gas exit stream is combined with the product fuel gas. Solids from the standpipe are returned to the gasifier. The unconverted carbon and partially sulfided sorbent are removed from the system by withdrawal from the primary cyclones and are sent directly to the transport sulfator. The gas leaving the cyclones is at $1455^{\circ} \mathrm{F}$ and contains small quantities of solids. It must be cooled to $1000^{\circ} \mathrm{F}$ and filtered prior to admission to the gas turbine.

\section{Heat Recovery}

Product gas leaving the gasifier secondary cyclone enters the fire-tube, downflow product gas cooler, where high-pressure steam is generated from BFW supplied by the HRSG steam drum. The water circulation from the steam drum to the product gas cooler is by natural convection. Heat is also recovered in the recycle gas cooler by preheating boiler feed water, which cools a small portion of fuel gas prior to compression for use as filter blowback gas.

\section{A.3.1.5 Gas Conditioning}

This area consists of two sections, namely, gas filtration and blowback gas compression, which are described below. Figure A-20 is the gas conditioning process flow diagram.

\section{Gas Filtration}

The cooled gas stream from the prcduct gas cooler flows to the gas filter, which removes all of the remaining particulates from the gas. These filters are of the ceramic-candletype and require periodic blowback. Fines collected in the gas filter are sent to the transport sulfator. The clean fuel gas, at about $1000^{\circ} \mathrm{F}$ and $280 \mathrm{psia}$, is sent directly to the gas turbine.

\section{Blowback Gas Compression}

A single-stage recycle compressor is employed here to compress a cooled slipstream of product gas for use as blowback gas. A gas receiver is included to provide the surge capacity necessary to accommodate the periodic flow of the blowback gas. 


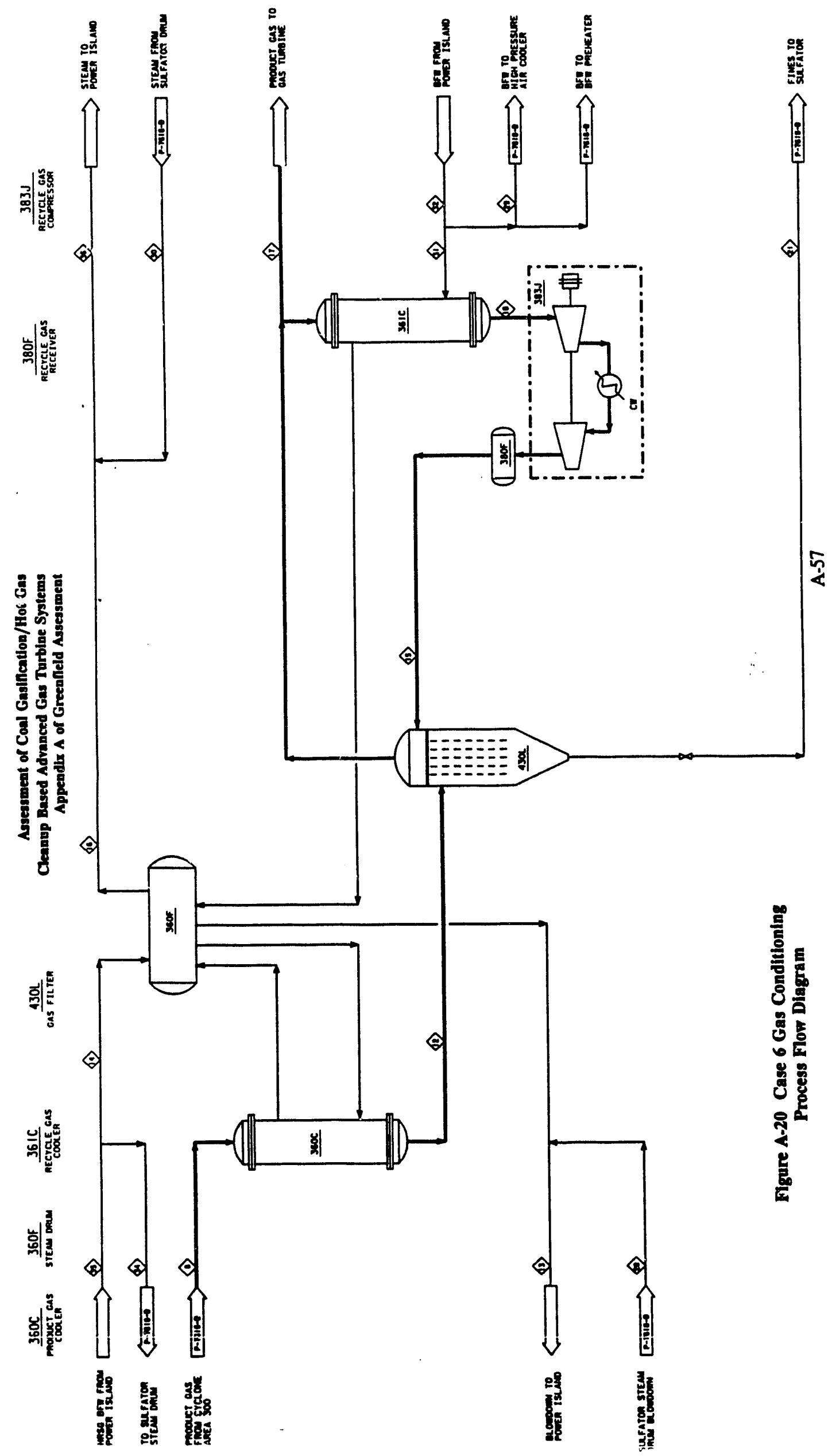




\section{A.3.1.6 Gasifier Solids Sulfation}

The process flow diagram for the sulfation step is illustrated in Figure A-21. Solids fed to the transport sulfator flow from the dipleg of the gasifier primary cyclone through two refractory-lined and adequately aerated return legs. The transport sulfator is made up of a mixing zone and a riser section. The char and sulfided limestone from the gasifier are injected in the mixing zone where they are mixed with hot recycled solids and primary air. Combustion of char, sulfur release, sulfur capture, and oxidation of calcium sulfide to calcium sulfate, start in the mixing zone. As the gas/solids mixture flows up through the riser at high velocity the sulfided sorbent in the feed from the gasifier is converted to $\mathrm{CaSO}_{4}$. Also, as residual char burns, sulfur is released as $\mathrm{SO}_{2}$. This is captured by the sorbent and converted to $\mathrm{CaSO}_{4}$. This reaction is expected to proceed fully because of the very fine particles used and the high degree of turbulence in the riser. Virtually complete $\mathrm{SO}_{2}$ removal is obtained in the sulfator. The exothermic heat of the combustion and sulfation reactions results in a relatively small increase in the gas/solids temperature leaving the reactor. The solids recirculation rate is set to control this temperature rise. Combustion of the char in the reactor is essentially complete.

The solids flow rate through the feed leg to the combustor is to be controlled by a plug valve. A mechanical valve is used in this leg to enable the gasifier and sulfator to be decoupled should this be required. The designed solids height in the feed leg is adequate to drive the char mixture into the mixing zone of the transport sulfator. Most of the air is fed to the mixing zone in the bottom of transport sulfator where it contacts char and sorbent fed from the gasifier system together with recycled solids from the fluid bed heat exchanger. Provisions are included to stage the combustion air feed in order to minimize $\mathrm{NO}_{\mathbf{x}}$ formation.

The gas/solids mixture leaves the sulfator at $1650^{\circ} \mathrm{F}$ and flows through primary cyclones where bulk solids separation occurs. The flue gas then flows through secondary cyclones where most of the remaining solids are recovered from the gas. Two primary and two secondary cyclones are required for each sulfator.

Solids collected in the primary and secondary cyclones are fed to fluid bed heat exchangers, where the net heat of reaction is removed by cooling of the solids. Steam coils are located in these fluidized beds. A slipstream of solids is taken from these exchangers and sent to bayonet boilers for additional heat removal. In all of these exchangers, BFW from the HRSG steam drum is imported to generate saturated steam at $1600 \mathrm{psig}$, which is exported to the power island for superheating and power generation. Water circulation between the sulfator steam drum and various exchangers that produce steam is maintained by natural convection. Fluidization air is required for all of these exchanger vessels and is supplied by a slip stream from the booster compressor. Air leaving these exchanger vessels flows through primary and secondary cyclones to remove entrained solids, which are returned to the bed. The cleaned air is then combined with the flue gas from the transport sulfator and fed to the sulfator barrier filter for final solids removal. 


\section{Assessment of Coal Gasification/Hot Gas \\ Cleanup Based Advanced Gas Turbine Systems \\ Appendix A of Greenfield Assessment}

The sulfator barrier filter is similar to that used in the gasification system, being of the ceramic candle type. Cleaned flue gas exits the filter at about $1650^{\circ} \mathrm{F}$ and is sent directly to the gas turbine. Compressed air at 585 psig is used for filter blowback. Air from the blowback air compressor is stored in the blowback air receiver which provides surge capacity required for periodic flow of blowback gas.

Most of the solids leaving the fluidized bed heat exchangers are recycled to the sulfator for further use. The net make of solids, which consists essentially of ash and spent sorbent, is sent to the high pressure ash cooler where the hot solids are cooled to about $300^{\circ} \mathrm{F}$. This vessel is fluidized with a small amount of air from the booster compressor, which then flows through an ash cooler cyclone for solids removal and is then combined with the flue gas feed to the gas filter. The ash cooling is accomplished via a coil in the fluid bed which preheats boiler feed water from the deaerator and supplies a portion of water to the sulfator steam drum.

Fines from the gas filters are collected in the ash depressurization hoppers together with ash/spent sorbent mixture from the high-pressure ash cooler. Two hoppers are provided per train. These vessels operate in parallel, with one filling while the other is depressurizing and discharging solids. Air from the blowback air receiver is used as pressurization gas. The ash depressu:zation vent filter removes any entrained dust during the depressurization cycle. After depressurization the solids are cooled by cooling water to $150^{\circ} \mathrm{F}$ in the ash screw conveyor and are then sent to disposal.

\section{A.3.1.7 Gas Turbine System}

The gas turbine configuration for Case 6 is similar to that developed for Case 1. (Refer to Section A.2.1.8.) Two advanced-design GE MS7001F combustion turbines form the basis of the power island. Figure A-22 shows the power island configuration for Case 6 .

The major flowsheet differences between the GE MS7001F designs for Cases 1 and 3 versus that for Case 6 are the heating value of the fuel produced by the gasifier island and the larger compressor discharge air extraction required for Case 6.

\section{A.3.1.8 HRSG System}

The heat recovery steam generator configuration for Case 6 is virtually identical to that developed for Case 1 with the only variations being differences in interface flows with the gasifier island and differences in steam or flue gas extractions for coal drying purposes. (Refer to Section A.2.1.9.) 
II

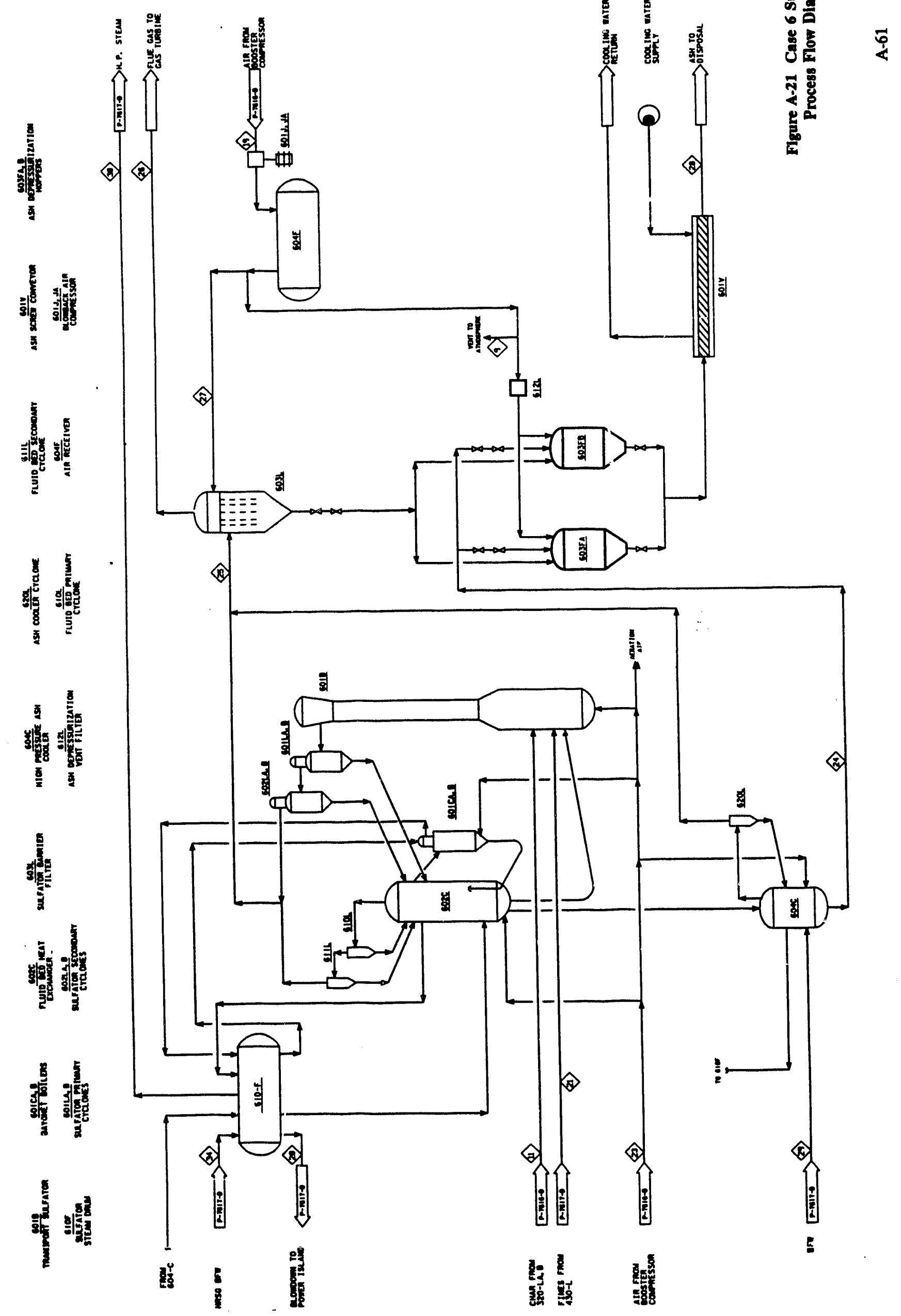




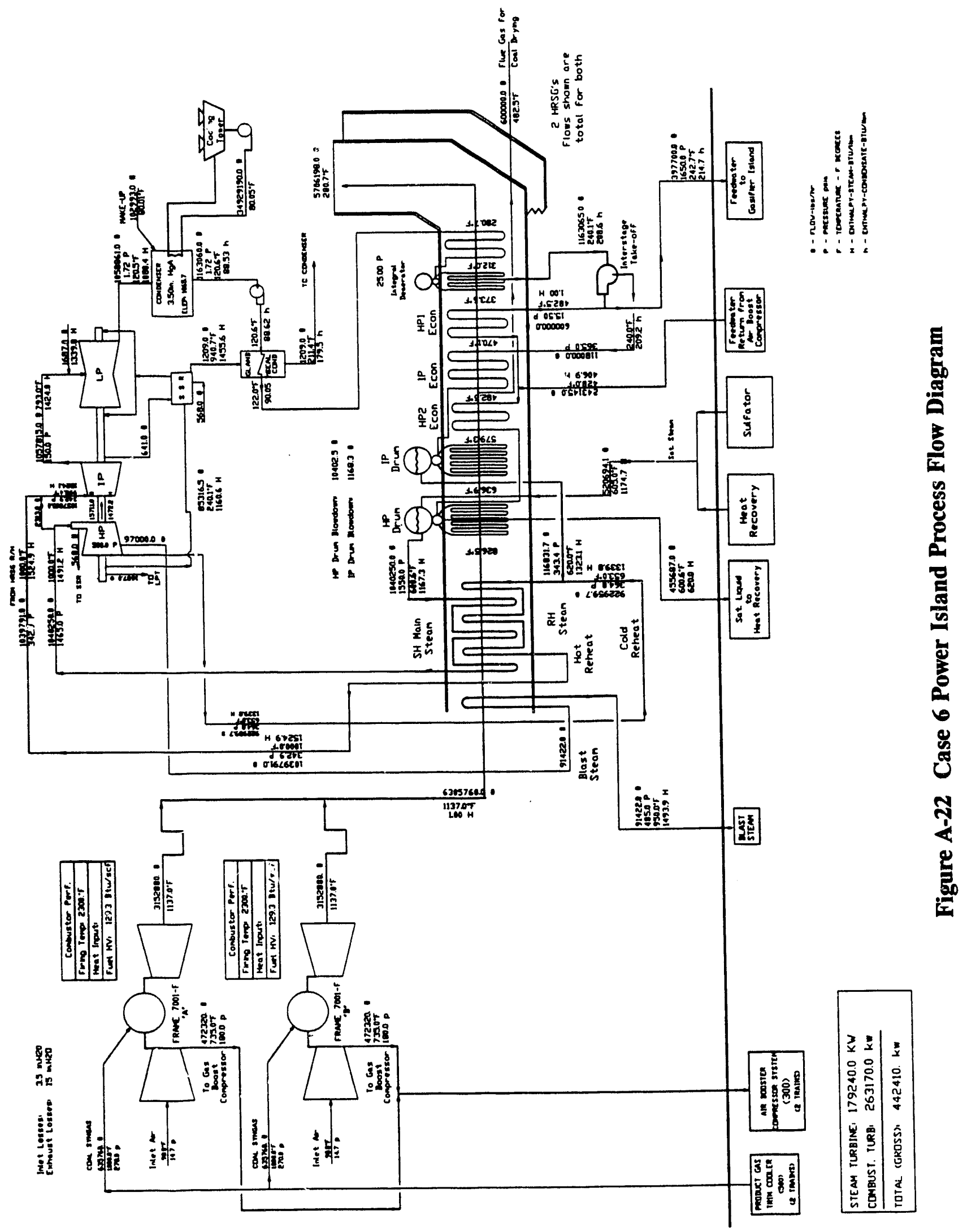


Assessment of Coal Gasification/Hot Gas

Cleanup Based Advanced Gas Turbine Systems

Appendix A of Greenfield Assessment

\section{A.3.1.9 Steam Turbine System}

The steam turbine configuration for Case 6 is virtually identical to that developed for Case 1, with the major variation being differences in interface flows with the gasifier island. (Refer to Section A.2.1.10.)

\section{A.3.2 Plant Layout}

The plant layout for Case 6 is illustrated in Figure A-23. A conceptual plot plan and elevation and isometric views of the gasification train for Case 6 are given in Figures A-24 and A-25, respectively.

\section{A.4 IGCC PLANT OPERATIONS AND PERFORMANCE (CASES 1, 3, AND 6)}

\section{A.4.1 Plant Equipment and Supplies}

\section{A.4.1.1 Spare Equipment and Material}

Equipment sparing was an important concern in the design of each IGCC case in order to achieve the desired reliability targets. The sparing approach for the power island and balance-of-plant portions of the plants is considered to be conventional and is not discussed in detail here. However, equipment sparing in the gasification island portions of the IGCC plants is dependent on the technology which has been selected, and can have a significant impact on operability and costs. Therefore, gasification island spare equipment was addressed in detail in the study.

There are two categories of gasification island capital spares included in the design cases: inline spare equipment and warehouse spare parts. Inline spares are those pieces of equipment that are permanently connected to the plant and are used only when a failure occurs in the piece of equipment being spared. These items are listed in Table A-4. Warehouse spare parts in this context are for major components and are in addition to those items included in normal spare part cost factors. Warehouse spares are itemized for the IGCC cases in Table A-5.

\section{A.4.1.2 Catalysts and Chemicals}

Initial catalysts and chemicals are included in the capital cost estimate as a separate line item. These material quantities are shown in Table A-6 for the various IGCC cases. Annual usages of these items are also provided as a basis for determination of operating costs. The recommendations for spare catalyst quantities are also shown in Table A-6 as inventory capital. The quantities shown are sufficient to replace a single reactor bed for each indicated catalyst. 


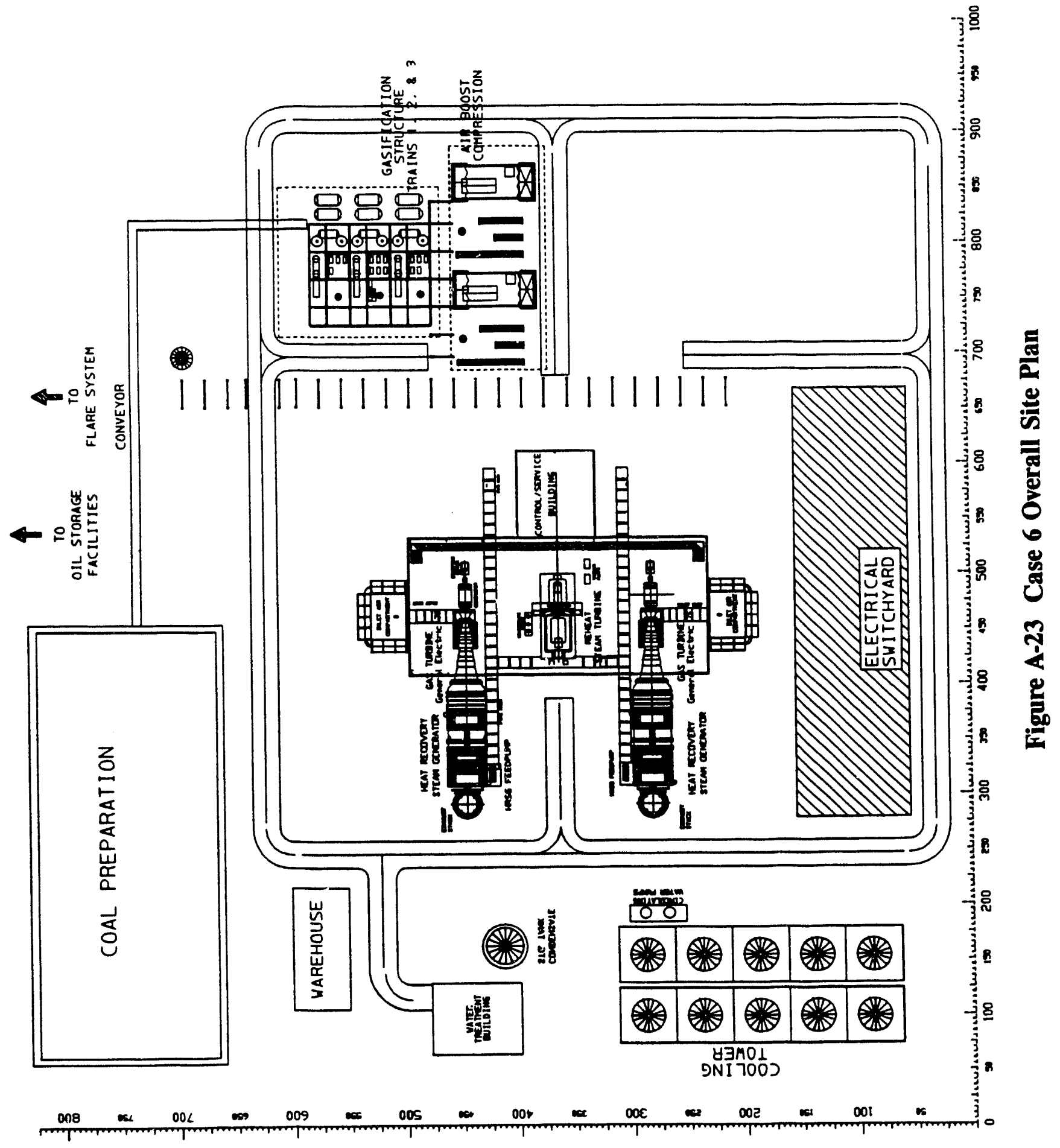


Table A-4

Inline Spare Equipment

\section{Items}

Coal Feeder (310-V)

Operational Units

Spare Units

Ash Feeder (330-V)

Operational Units

Spare Units

Recycle Gas Compressor (381-J)

Operational Units

Spare Units

Sulfator Vent Fan

Operational Units

Spare Units
Numbers of Units

Case 1 Case 3 Case 6

$\begin{array}{lll}4 & 2 & 3 \\ 2 & 1 & 1\end{array}$

$\begin{array}{lll}4 & 2 & 3 \\ 2 & 1 & 1\end{array}$

$4 \quad 2 \quad 3$

$2 \quad 1 \quad 1$

$\begin{array}{lll}3 & 2 & - \\ 3 & 2 & -\end{array}$

Table A-5

Major Component Warehouse Spares

Items

Ceramic Candle Filters

Operational Elements

Spare Elements

Hot Gas Valves (18 inch)

Operational Valves

Spare Valves

Hot Solids Valves

Operational Valves

Spare Valves

Sulfator Conveyor

Operational Units

Spare Units (602 V)

Spare Units (603 V)
Numbers of Units

Case 1 Case 3 Case 6

$\begin{array}{ccc}3928 & 1964 & 3285 \\ 400 & 300 & 400\end{array}$

32

2

16

1

$\begin{array}{rrr}20 & 10 & 24 \\ 4 & 2 & 4\end{array}$

$\begin{array}{lll}3 & 2 & 3 \\ 1 & 1 & 1 \\ 1 & 1 & 1\end{array}$ 


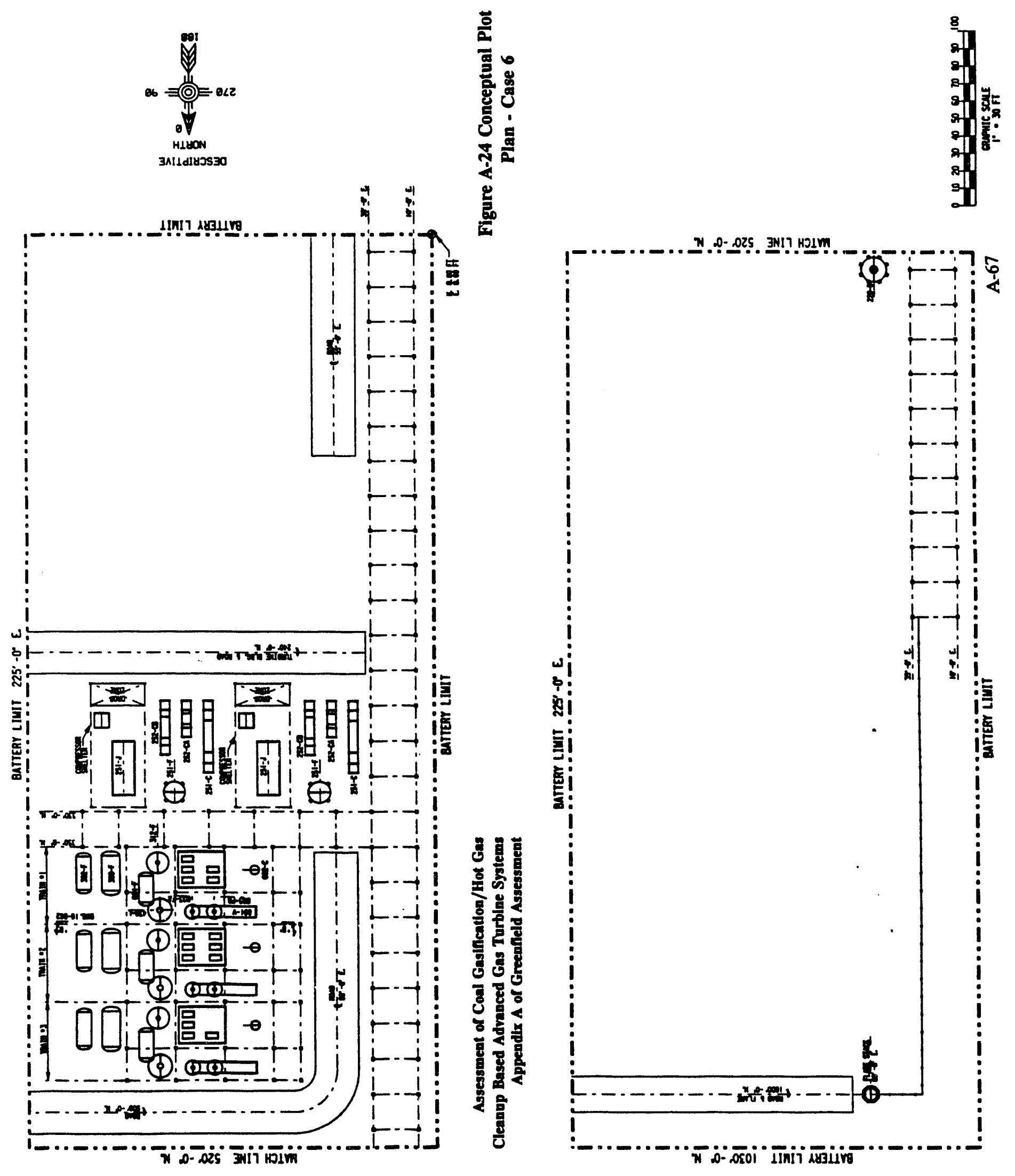



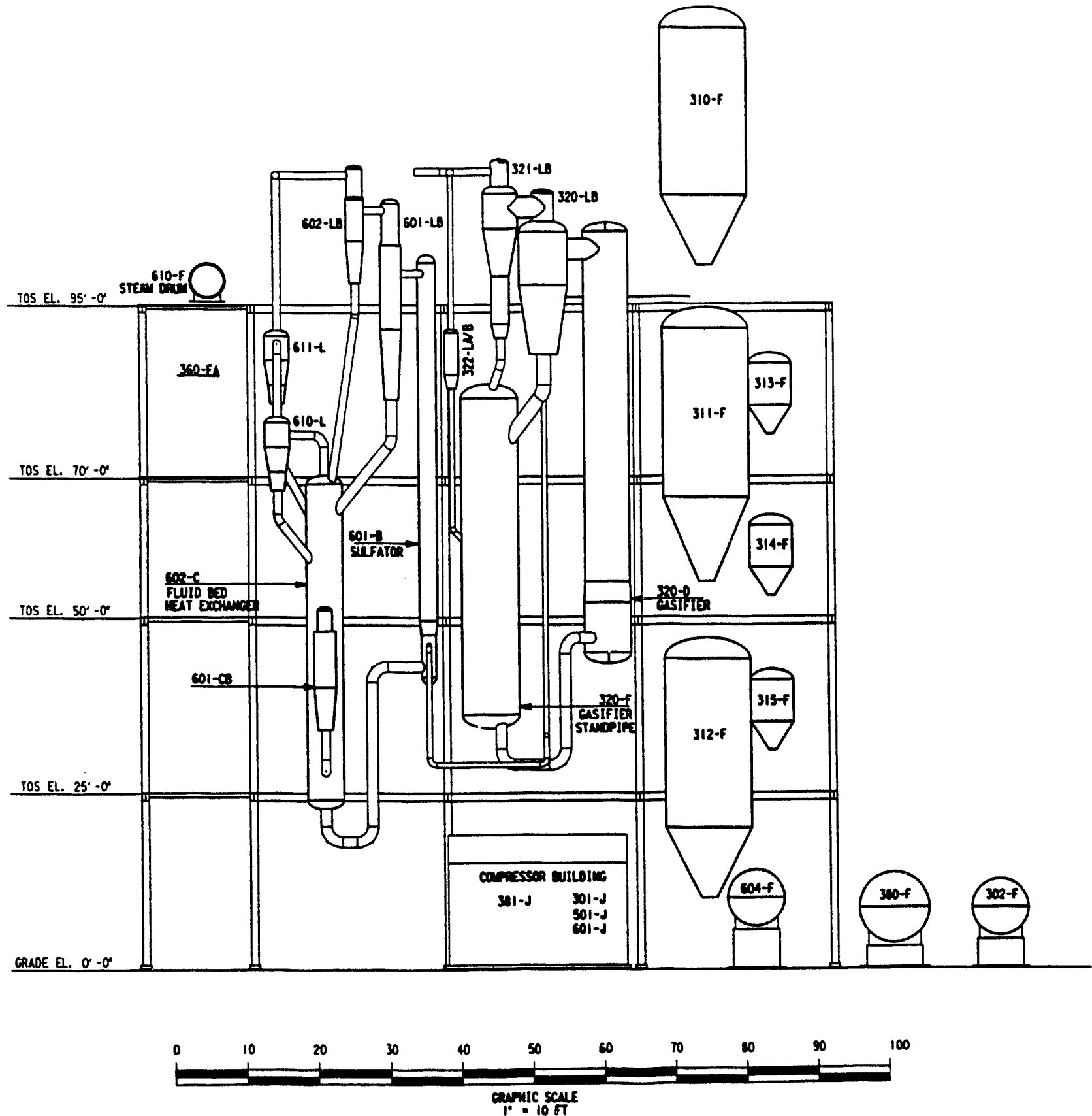

Figure A-25 (Sheet 1 of 2) Gasification Train Layout, Elevation View - Case 6 


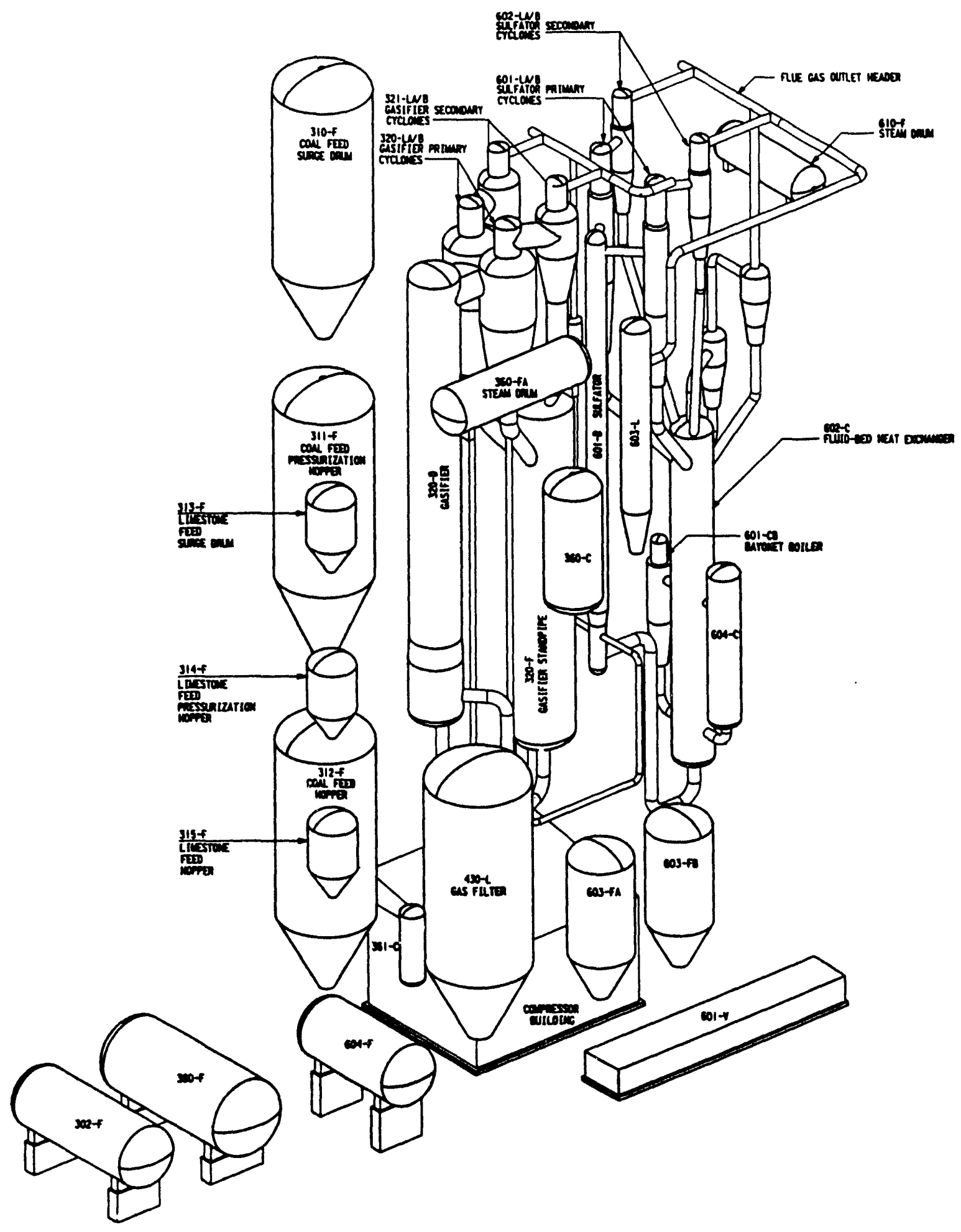

Figure A-25 (Sheet 2 of 2) Gasification Train Layout, Elevation View - Case 6 
Table A-6

\section{Catalysts and Chemicals}

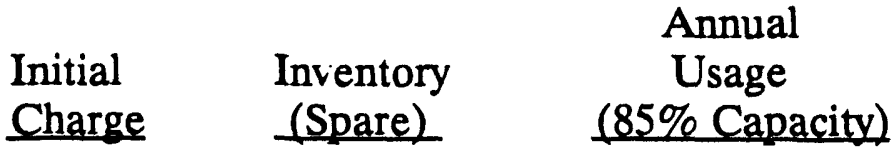

Case 1

Nahcolite (tons)

740

1,600

200

1,482

Zinc Ferrite (tons)

370

800

200

741

173

Case 6

There is no major catalyst or chemical usage for Case 6.

\section{A.4.1.3 Spare Capacity}

As part of the design process, reliability analysis was used to determine the equipment sparing requirements in order to achieve availability targets. This process was applicable primarily to the gasification island. The gasifier island equipment components are designed with excess capacity. Should it be necessary to idle or shut down one gasifier train, the capacity of the remaining trains can be increased to make up for a portion of the inoperative gasifier train output. A gasifier train consists of all equipment from the pressurization of feedstocks to the production of clean gas at the exit of the external desulfurizer. The complete train will be isolated and taken out of service if a component failure requires depressurization for repair. This excess capacity and the capacity less one operating train are shown for the IGCC cases in Table A-7. 
Table A-7

Spare Capacities

Case Number

Items

No. Gasifier Trains

Excess Capacity, \%

Capacity, Less One Train,\%

Equivalent Availability

of Gasifier Island
Case 1 Case 3 Case 6

4

19

89

95
2

19

59

93
3

26

84

96

\section{A.4.1.4 Equipment Reliability}

A reliability-availability-maintainability (RAM) analysis was conducted for each of the IGCC plant designs (Cases 1,3 , and 6 ) to determine equipment reliability. The results of the RAM analyses were compared to an equivalent availability (EA) goal of 85 percent for the large $(400 \mathrm{MW})$ plants and a 65-percent minimum for the small (200 MW) plant, Case 3.

The EPRI computer code, UNIRAM, was used as the analysis tool. UNIRAM was developed for EPRI by ARINC Research Corporation and has been in use since the early 1980s. The basic objective of UNIRAM is to relate failures or combinations of failures at the component level to the resultant curtailment, if any, of the power plant. UNIRAM calculates predicted estimates of equivalent availability (EA) and other performance measures.

The RAM model and analysis have been used not only to provide estimates of expected plant performance but also as an interactive tool in refining the plant designs to assist in optimizing the designs by balancing cost with performance.

\section{A.4.2 Process Performance}

\section{A.4.2.1 Heat and Material Balances}

Heat and material balances were conducted separately for the gasification island and power island of the plant. The material balances for the gas island conducted by MWK 
were performed using the ASPEN process simulation computer model which takes into account the proper energy flows in deriving the material balance. The power island used a SYNTHA thermal modeling computer program to determine the heat and material balances based on the interface points with the gas island.

The overall plant material balances for Cases 1, 3, and 6 are summarized in Table A-8. The material descriptions cover all four cases and thus some items do not apply to all cases.

\section{A.4.2.2 Gasifier Island Performance and Interfaces}

Gasifier island performance and interface parameters are summarized in Table A-9, which shows the quantities of plant feeds to the process and the gasifier island products produced. In this table, performance of the various cases are compared by cold gas efficiency, carbon conversion, and sulfur removal. Interface parameters between the gasification and power islands are summarized in Table A-10. These parameters are reflected in the material balances presented in earlier sections.

\section{A.4.2.3 Power Island Performance}

Four major areas were the focus for developing the thermal cycle: (1) combustion turbine configuration, (2) HRSG configuration, (3) steam turbine island, and (4) interface points with the gasifier island. A thermal model of each of the cases was developed using the SYNTHA thermal modeling computer program. The thermal model was based on the equipment configurations and interface flows previously described. The following major design points were utilized in the development of the thermal model:

- Reheat steam turbine design based on General Electric $1450 \mathrm{psig}, 1000^{\circ} \mathrm{F} / 1000^{\circ} \mathrm{F}$ design with 2-flow IP/LP section and 23-inch last stage blades - cold reheat pressure $350 \mathrm{psi}$

- HRSG - dual pressure with 1600-psi HP drum and 350-psi IP drum, integral deaerator and feedwater heating coil - overall 1.5-percent heat loss per section, 1-percent HP and IP drum blowdown

- Condenser pressure - 3.5-inch HgA

- Deaerator pressure -25 psi to provide $240^{\circ} \mathrm{F}$ feedwater temperature

- Boiler feedpump discharge pressure -1650 psi to allow for 13-percent pressure drop through HRSG

- LP turbine exhaust losses based on 23-inch LSB with 32.9 sq. $\mathrm{ft}$. annulus area 
Table A-8

\section{Overall Material Balances - IGCC Cases}

Material In, lb/hr

Limestone (Dried)

Coal (As Received)

EFW Makeup

Combustion Air to Gas Turbine

Cooling Tower Makeup

Air to Sulfator

Filter Blowback Air

Air Compressor Feed to Gasifier

Nitrogen to Coal Preparation

Coal Drying dilution Air

Total Material In

Material Out. $\mathrm{lb} / \mathrm{hr}$

HRSG Stack Gas to Main Stack

Coal Drying Gas to Local Stack

Solids to Disposal

$\mathrm{ZnFe}$ Regeneration Gas to Acid Plant

Vent Gas to Atmosphere

Vent Fuel Gas to Flare

Boiler Blowdown

Cooling Tower Blowdown, Evap., Drift

Total Material Out

\section{Closure}

Case 1 Case 3 Case 6

$\begin{array}{rrr}87,733 & 43,866 & 35,936 \\ 336,573 & 168,287 & 285,212 \\ 460,924 & 230,462 & 102,883 \\ 4,909,830 & 2,454,923 & 5,033,400 \\ 3,485,164 & 1,742,582 & 3,530,231 \\ 195,650 & 97,825 & 120,902 \\ -- & -- & 3,328 \\ 1,073,957 & 536,979 & 820,313 \\ --- & -- & -- \\ 218,665 & 109,224 & -- \\ 10,768,496 & 5,384,148 & 9,932,205\end{array}$

$6,740,748$

$3,370,385$

$102,576 \quad 51,288 \quad 66,455$

$102,576 \quad$ - $\quad$ - $\quad$ -

$\begin{array}{rrr}- & -. & 1,513 \\ 1,261 & 631 & --\end{array}$

$14,448 \quad 7,224 \quad 11,411$

3,$485 ; 164 \quad 1,742,582 \quad 3,530,231$

$10,768,536 \quad 5,384,170 \quad 9,931,773$

$100.00 \% \quad 100.00 \% \quad 100.00 \%$ 
Table A-9

Gas Island Design Basis Performance Comparison

Case 1 Case 3 Case 6

\section{FEEDS}

Coal Feed (T/Day,

$\begin{array}{lrrr}\text { After Drying) } & 3,792 & 1,896 & 3,213 \\ \text { Limestone Fee (T/Day) } & 1,053 & 526 & 431 \\ \text { Air Supply (T/Day) } & 12,888 & 6,444 & 11,334 \\ \text { Steam (MMLb/Day) } & & & \\ 450 \mathrm{lb} & 5,357 & 2,678 & 1,092^{*} \\ 850 \mathrm{lb} & --. & - & - \\ \quad \text { Solids Waste (T/Day) } & 1,231 & 615 & 795\end{array}$

Oxygen ( $T /$ Day)

PRODUCTS

$\begin{array}{lrrr}\begin{array}{l}\text { Fuel Gas (LHV, } \\ \text { MMBtu/Day) }\end{array} & 63,336 & 31,668 & 59,757 \\ \begin{array}{l}\text { Steam (MMLb/Day) } \\ \text { 1600 lb SAT. }\end{array} & 12,447 & 6,224 & 6,160 \\ \quad \text { 850 lb SAT. } & -- & -- & - \\ \begin{array}{l}\text { PERFORMANCE } \\ \text { Cold Gas Efficiency- }\end{array} & & & \\ \quad \text { LHV (\%) } & 69.7 & 69.7 & 77.6 \\ \quad \begin{array}{l}\text { Carbon Conversion (\%) } \\ \quad \text { Gasifier Only }\end{array} & 96.5 & 96.5 & 98.2 \\ \quad \text { Gas Island } & 99.9 & 99.9 & 9.9 \\ \quad \begin{array}{l}\text { Sulfur Removal (\%) } \\ \quad \text { Gasifier Only }\end{array} & 86.5 & 86.5 & - \\ \quad \text { Gas Island } & 99.4 & 99.4 & 99.2\end{array}$

* 350 psig steam supply pressure is adequate for Case 6 . 
Table A-10

MWK/SCS Interface Parameters

\begin{tabular}{|c|c|c|c|}
\hline GASIFIER/POWER ISLAND INTERF & Case 1 & Case 3 & Case 6 \\
\hline $\begin{array}{l}\text { Coal (Sized) } \\
\text { Flow, lb/hr } \\
\text { Temp, deg }^{\circ} \text { F } \\
\text { Pressure }\end{array}$ & $\begin{array}{r}315,975 \\
200 \\
\text { Amb }\end{array}$ & $\begin{array}{r}157,988 \\
200 \\
\text { Amb }\end{array}$ & $\begin{array}{r}267,757 \\
200 \\
\text { Amb }\end{array}$ \\
\hline $\begin{array}{r}\text { Limestone (Sized) } \\
\text { Flow, lb/hr }\end{array}$ & 87,733 & 43,866 & 35,936 \\
\hline $\begin{array}{l}\text { Process Air } \\
\text { Flow, lb } / \mathrm{hr} \\
\text { Temp, deg }{ }^{\circ} \mathrm{F} \\
\text { Pressure, psia }\end{array}$ & $\begin{array}{r}1,073,957 \\
760 \\
200\end{array}$ & $\begin{array}{r}536,979 \\
760 \\
200\end{array}$ & $\begin{array}{r}944,543 \\
740 \\
185\end{array}$ \\
\hline $\begin{array}{l}\text { Product Gas } \\
\text { LHV, Btu/SCF } \\
\text { Flow, MMBtu/hr (LHV) }\end{array}$ & $\begin{array}{r}87.4 \\
2,639\end{array}$ & $\begin{array}{l}87.4 \\
1,320\end{array}$ & $\begin{array}{l}137.9 \\
2,490\end{array}$ \\
\hline
\end{tabular}

BFW From Power Island

Flow, lb/hr

Temp ${ }^{\circ} \mathbf{F}$

Pressure, psia

$812,273 / 486,088$

BFW To Power Island

Flow, lb/hr

Temp ${ }^{\circ} \mathbf{F}$

Pressure, psia

Steam From Power Island

Flow, lb/hr

Temp ${ }^{\circ} \mathrm{F}$

Pressure, psia

Steam To Power Island

Flow, lb/hr

Temp ${ }^{\circ} \mathrm{F}$

Pressure, psia

Solids to Disposal, $\mathrm{lb} / \mathrm{hr}$
$600 / 240$

1,650

$406,136 / 243,044$

$600 / 240$

$5,186 / 125,360$
$605 / 428$
1,600

$$
\begin{array}{r}
56,699 / 389,707 \\
950 / 500 \\
450 / 450
\end{array}
$$

$28,349 / 194,954$
$950 / 500$
$450 / 450$

$1,037,268$

605

1,600

102,576

188,754

1,400

347

174
1,650

$453,768 / 306,853$

$600 / 240$

1,650

$5,134 / 242,121$

$605 / 345$

1,600

91,037

950

350

513,367

605

1,600

66,455

51,288

94,377

1,400

113,568

1,619

Vent Gas to Flare, SCFW 
Many model iterations were run to optimize the power output of the steam turbine. The two major points used to establish optimum steam flows were the HP evaporator pinch point and the HRSG exhaust temperature. Based on the composition of the exhaust gas, $280^{\circ} \mathrm{F}$ was set as the minimum exhaust gas temperature in order to minimize acidic deposition and avoid stack corrosion. The HP evaporator pinch point was varied with lower pinch points naturally providing higher overall power production. A value of $35^{\circ} \mathrm{F}$ was established as the design value for the HP evaporator pinch point based on a tradeoff between improved performance and higher capital cost.

\section{Gas Turbine Performance}

The gas turbine performance provided by General Electric was based on the applicable site conditions for Plant Wansley. The GE MS7001F design would be virtually identical to the design for a natural-gas-firing GE MS7001F with the exceptions of special considerations for the bleeding of compressor discharge air to the gasifier island and adjustments for high-temperature, low-Btu fuel gas flow to the combustor. Both of these areas require further research and testing before the GE MS7001F could be considered commercially operational for this application.

One important factor employed by General Electric in developing the performance data for the GE MS7001F was the use of the flat rating concept. As combustion turbines are constant volume machines, their output is highly dependent on the density of air, which is greatly affected by changes in ambient temperature. Lower ambient temperatures result in higher output due to higher air densities and, therefore, more mass flow through the gas turbine. Higher ambient temperatures result in lower output due to decreases in air density.

Table A-11 shows design information produced by General Electric regarding the calculated performance of the MS7001F using the coal gas compositions developed for Cases 1 and 3. Table A-12 shows design information produced by General Electric regarding the calculated performance of the GE MS7001F using the coal gas for Case 6. Table A-13 summarizes the performance data for the combustion turbines for all four IGCC cases at the $90^{\circ} \mathrm{F}$ design point. The gas turbine performance data is based on operation under the flat rating design scheme previously described.

\section{Steam Turbine Performance}

Using the SYNTHA thermal modeling program, a computer model of the steam cycle (HRSG and steam turbine) was developed. Using the gas turbine exhaust conditions developed by General Electric, corresponding steam turbine performance data were developed based on the HRSG(s) receiving the exhaust flow from the combustion turbine(s). The thermal model was developed using the gasifier interface flows previously described. Table A-14 shows the summary of the performance data developed for the steam turbine. 
Table A-11

\section{GE MS7001F Performance - Flat Rating}

Cases 1 and 3

$\begin{array}{llll}\text { Ambient Temperature }\left({ }^{\circ} \mathrm{F}\right) & 20 & 59 & 90 \\ \text { Relative Huraidity (\%) } & 60 & 60 & 60 \\ \begin{array}{l}\text { GT COMPRESSOR AIR TO } \\ \text { GASIFIER ISLAND }\end{array} & & & \\ \text { Ratio to fuel gas } & 0.5869 & 0.5869 & 0.5869 \\ \text { Mass flow (lb/sec) } & 149.1 & 149.1 & 149.1 \\ \left.\text { Temperature ( }{ }^{\circ} \mathrm{F}\right) & 635 & 695 & 760 \\ \text { Pressure (psia) } & 185 & 190 & 200 \\ \text { FUEL GAS FLOW TO GT } & & & \\ \text { Heating Value (LHV, Btu/scf) } & 87.4 & 87.4 & 87.4 \\ \text { Mass flow (lb/sec) } & 254.1 & 254.1 & 254.1 \\ \left.\text { Temperature ( }{ }^{\circ} \mathrm{F}\right) & 1000 & 1000 & 1000 \\ \text { Pressure (psia) } & 285 & 290 & 295 \\ & & & \\ \text { GENERATOR OUTPUT (kW) } & 160,410 & 160,410 & 155,820 \\ \text { TURBINE EXHAUST FLOW } & & & \\ \text { Mass Flow (lb/sec) } & & 918.9 & 935.5 \\ \text { Temperature ( }{ }^{\circ} \text { F) } & 900.8 & 1093 & 1098\end{array}$

Site elevation

Barometric pressure (sea level)

Inlet air pressure loss

Exhaust pressure loss

Steam injection for $\mathrm{NO}_{\mathbf{x}}$ control

Supplementary fuel

Generator power factor

GT auxiliary load (not included above)
725 feet

14.7 psia

3.5 in. $\mathrm{H}_{2} \mathrm{O}$

15 in. $\mathrm{H}_{2} \mathrm{O}$

none

none

0.9

$775 \mathrm{~kW}$ 
Table A-12

GE MS7001F Performance - Flat Rating

Case 6

$\begin{array}{llll}\text { Ambient Temperature }\left({ }^{\circ} \mathrm{F}\right) & 20 & 59 & 90 \\ \text { Relative Humidity (\%) } & 60 & 60 & 60\end{array}$

GT COMPRESSOR AIR TO

GASIFIER ISLAND

Ratio to fuel gas

0.816

0.816

0.816

Mass flow (lb/sec)

131.2

131.2

131.2

Temperature $\left({ }^{\circ} \mathrm{F}\right)$

610

670

735

Pressure (psia)

170

175

180

FUEL GAS FLOW TO GT

Heat Value (LHV, Btu/scf)

138

138

138

Mass flow (lb/sec)

160.8

160.8

160.8

Temperature $\left({ }^{\circ} \mathrm{F}\right)$

1000

1000

1000

Pressure (psia)

260

265

270

GENERATOR OUTPUT (kW)

133,730

134,035

131,585

TURBINE EXHAUST FLOW

Mass Flow (lb/sec)

840.2

859.9

875.8

Temperature ( $\left.{ }^{\circ} \mathrm{F}\right)$

1143

1138

1137

RELEVANT SITE CONDITIONS

Site elevation

Barometric pressure (sea level)

Inlet air pressure loss

Exhaust pressure loss

Steam injection for $\mathrm{NO}_{\mathrm{z}}$ control

Supplementary fuel

Generator power factor

GT auxiliary load (not included above)
725 feet

14.7 psia

3.5 in. $\mathrm{H}_{2} \mathrm{O}$

15 in. $\mathrm{H}_{2} \mathrm{O}$

none

none

0.9

$775 \mathrm{~kW}$ 
Table A-13

\section{Combustion Turbine Performance Summary} $90^{\circ}$ F Design Point

\begin{tabular}{|c|c|c|c|}
\hline & Case 1 & Case 3 & Case 6 \\
\hline $\begin{array}{l}\text { Power Output } \\
\text { per CT }(\mathrm{kW})\end{array}$ & 155,820 & 155,820 & 131,585 \\
\hline $\begin{array}{l}\text { Total CT } \\
\text { Power Output (kW) }\end{array}$ & 311,640 & 155,820 & 263,170 \\
\hline $\begin{array}{l}\text { CDP Conditions } \\
\text { Temperature }\left({ }^{\circ} \mathrm{F}\right) \\
\text { Pressure (psia) }\end{array}$ & $\begin{array}{l}760 \\
200\end{array}$ & $\begin{array}{l}760 \\
200\end{array}$ & $\begin{array}{l}735 \\
180\end{array}$ \\
\hline Exhaust Temperature $\left({ }^{\circ} \mathrm{F}\right)$ & 1098 & 1098 & 1137 \\
\hline \multirow[t]{3}{*}{ Exhaust Flow (lb/sec) } & 935.5 & 935.5 & 875.8 \\
\hline & \multicolumn{2}{|c|}{$\begin{array}{l}\text { Table A-14 } \\
\text { Performance Data - IGCC Cases }\end{array}$} & \\
\hline & Case 1 & Case 3 & Case 6 \\
\hline Throttle Flow (lb/hr) & $1,344,245$ & 672,123 & $1,048,665$ \\
\hline Reheat Flow (lb/hr) & $1,025,827$ & 512,914 & 936,954 \\
\hline Makeup Flow (lb/hr) & 460,924 & 230,462 & 102,833 \\
\hline HRSG Exhaust Temp $\left({ }^{\circ} \mathrm{F}\right)$ & 280.1 & 281.3 & 280.1 \\
\hline $\begin{array}{l}\text { Steam Turbine Gross } \\
\text { Power Output }(\mathrm{kW})\end{array}$ & 182,190 & 94,008 & 178,410 \\
\hline $\begin{array}{l}\text { Total CT } \\
\text { Power Output (kW) }\end{array}$ & 311,640 & 155,820 & 263,170 \\
\hline $\begin{array}{l}\text { Total Gross } \\
\text { Power Output (kW) }\end{array}$ & 493,830 & 249,828 & 441,580 \\
\hline
\end{tabular}




\section{Station Service Calculations}

Based on the thermal cycles developed for Cases 1,3, and 6, major equipment was sized and station-service power requirements determined. Table A-15 provides the breakdown of station-service values for the complete IGCC plants including the power island, gasifier island, and coal and limestone handling areas.

\section{Net Power Island Performance}

Table A-16 shows the calculated net power output for Cases 1, 3, and 6. The net power values are merely the gross power outputs of the power island less the station- service requirements of the power island, gasifier island, and coal/limestone handling facilities. The fuel consumption, and consequently the heat rates, shown in Table A-16 are based on the design flow rates of the coal to the gasifier island on a higher heating value (HHV) basis (12,469 Btu/lb as prepared, after drying). 
Table A-15

Detailed Plant Station Service Values - IGCC Cases (All Values in Kilowatts)

Gasifier Island Booster Air Compressor

KRW Gasification

Recycle Gas

Compression

Sulfation

Miscellaneous

Tptal Gasifier

Island

Power Island

HRSG Feedpumps

Condensate Pumps

Circ. Water Pumps

Cooling Tower Fans

Vacuum Pumps

Service Water Pumps

Make-up Pumps

Service Air System

Gas Turbine Aux.

Steam Turbine Aux.

Water Treatment

Powerhouse

Service Building/

Control Room

Total Power

Island

Coal \& Limestone

Handling

Total

\section{Case 1 Case 3 Case 6}

$\begin{array}{lll}17,341 & 8,670 & 17,476\end{array}$

$1,004 \quad 502 \quad 729$

$\begin{array}{lll}1,714 & 857 & 254\end{array}$

$1,281 \quad 641 \quad 53$

$\frac{320}{21,660} \quad \frac{160}{10,830} \quad \frac{250}{18,762}$

$3,420 \quad 1,710 \quad 2,742$

$144 \quad 72 \quad 115$

$2,027 \quad 1,014 \quad 2,083$

$1,600 \quad 800 \quad 1,645$

$400 \quad 200 \quad 400$

$227 \quad 114 \quad 227$

$\begin{array}{lll}19 & 9 & 5\end{array}$

$\begin{array}{llr}149 & 75 & 149\end{array}$

$\begin{array}{lll}1,550 & 775 & 1,550\end{array}$

$1,500 \quad 750 \quad 1,500$

$\begin{array}{lll}320 & 160 & 77\end{array}$

$\begin{array}{lll}15 & 10 & 15\end{array}$

$\frac{18}{11,389} \quad \frac{12}{5,701} \quad \frac{18}{10,526}$

$\frac{2,372}{35,421} \quad \frac{1,621}{18,152} \quad \frac{2,765}{32,053}$ 
Table A-16

Overall Performance Summary for IGCC

Cases 1,3 , and $6\left(90^{\circ} \mathrm{F}\right)$

Gross Power

Case 1 Case 3 Case 6

Output (kW)

$493,830 \quad 249,828 \quad 441,580$

Gasifier Island

$21,660 \quad 10,803 \quad 18,762$

Station

Service (kW)

Power Island

11,389

5,701

10,526

Station

Service $(\mathrm{kW})$

Coal/Limestone

2,372

1,621

2,765

Handling Station

Service (kW)

Net Plant

$458,409 \quad 231,703 \quad 409,527$

Power Output (kW)

Fuel Consumption

3,940

1,970

3,339

(MMBtu/hr - HHV)

Net Plant Heat Rate

8,595

8,503

8,153

(Btu/kWh - HHV) 


\section{APPENDIX B \\ DETAILED COST OF ELECTRICITY \\ RESULTS FOR GREENFIELD ASSESSMENT \\ (DOE MODEL) \\ CASES 1, 3, AND 6}


Table B-1

Greenfield/Hot Gas Cleanup Case 1

458 MW Power Plant

Capital Requirements (Mid-1990 Dollars)

Total Plant Investment

Area

No. Plant Section Description

Process

Cost,K\$

Cont. K\$

W/O Cont

100 Coal Receiving, Handling \& Prep

$\$ 20,362$

150 Limestone Receiving, Hand \& Pre

$\$ 11,693$

250 Booster Compression

$\$ 8,822$

300 KRW Gasification

$\$ 55,163$

380 Recycle Gas Compression

$\$ 5,035$

$\$ 13,939$

400

Gas Conditioning

$\$ 1,430$

$\$ 35,212$

500 External Desulfurization

$\$ 1,548$

$\$ 20,171$

600 Sulfation

$\$ 2,043$

$\$ 13,091$

700 Sulfuric Acid Plant

$\$ 0$

$\$ 0$

900 Gas Turbine System

$\$ 3,630$

$\$ 71,120$

1000 HRSG System

$\$ 1,277$

$\$ 25,042$

1100 Steam Turbine System

$\$ 0$

$\$ 46,491$

1200 Ash \& Fines Handling \& Disp

$\$ 0$

$\$ 13,444$

1300 General Facilities

$\$ 0$

$\$ 334,550$

Subtotal, Process Plant Cost

$\$ 37,235$

General Plant Facilities

$\$ 27,766$

Engineering Fees

$\$ 19,810$

Process Contingency (Using contingencies listed above)

$\$ 83,872$

Project Contingency, $20 \%$ Proc Plt \& Gen Plt Fac

$\$ 503,233$

Total Plant Cost (TPC)

$\$ 93,700$

Adjustment for Interest and Inflation (AFUDC)

$\$ 596,933$

Total Plant Investment (TPI)

$\$ 1,890$

Prepaid Royalties

$\$ 10,642$

Initial Catalyst and Chemical Inventory

$\$ 15,324$

Startup Costs

$\$ 7,834$

Spare Parts

$\$ 9,883$

Working Capital

$\$ 2,828$

Land, 435 Acres

$\$ 645,333$

Total Capital Requirement (TCR) 


\section{ANNUAL OPERATING COSTS}

Capacity Factor $=65 \%$

Cost Item

Quantity

Unit \$

Annual

Ill. No. 6 Coal Fuel Type

4053.1 T/D

Price

Cost. KS

Consuriable Materials

Limestone

Nahcolite

Zinc Ferrite

Miscellaneous

$1085.6 \mathrm{~T} / \mathrm{D}$

$4.8 \mathrm{~T} / \mathrm{D}$

$1.1 \mathrm{~T} / \mathrm{D}$

$2509.6 \mathrm{~T} / \mathrm{D}$

Ash/Sorbent Disposal Costs

$1231.0 \mathrm{~T} / \mathrm{D}$

$\$ 35.00 / \mathrm{T}$

$\$ 33,656$

Plant Labor

Oper Labor (incl benef)

$23 \mathrm{Men} / \mathrm{shift}$

Supervision \& Clerical

Maintenance Costs

$\$ 11.20 / \mathrm{T}$
$\$ 261.25 / \mathrm{T}$
$\$ 6,270 / \mathrm{T}$
$\$ 1.00 / \mathrm{T}$

$\$ 2,885$

$\$ 296$

$\$ 1,648$

$\$ 595$

$\$ 2.94 / \mathrm{T}$

$\$ 859$

Insurance \& Local Taxes

$\$ 21.80 / \mathrm{Hr}$.

$\$ 4,380$

$\$ 1,691$

$\$ 8,921$

$\$ 3,019$

Royalties

Other Operating Costs

$\$ 564$

Total Operating Costs

$\$ 58,514$

Total By-Product Credits

$\$ 0$

Net Operating Costs

$\$ 58,514$ 


\section{BASES AND ASSUMPTIONS}

\section{A. CAPITAL BASES AND DETAILS}

QUANTITY UNIT \$ PRICE COST, K\$

Initial Catalyst Inventory

Gasification

- $\mathrm{lb}$.

$/ \mathrm{lb}$.

$\$ 10,583$

Initial Chemicals Inventory

Miscellaneous

$59000 \mathrm{lb}$.

$\$ 1.00 / \mathrm{lb}$.

$\$ 59$

Total Catalyst and Chemical Inventory

$\$ 10,642$

Startup costs

Plant modifications, $2 \%$ TPI

$\$ 11,939$

Operating costs

$\$ 2,321$

Fuel

$\$ 1,064$

Total Startup Costs

$\$ 15,324$

Working capital

Fuel \& Consumables inv, 60 days supply

$\$ 9,883$

By-Product inventory, 30 days supply

Direct expenses, 0 days

$\$ 0$

Total Working Capital

$\$ 9,883$

\section{B. ECONOMIC ASSUMPTIONS}

Project life

Book life

Tax life

Federal and state income tax rate

Tax depreciation method

Investment Tax Credit
30 Years

30 Years

20 Years

$37.7 \%$

ACRS

$0.0 \%$

Financial structure

Type of Security

Debt

Preferred Stock

Common Stock

Discount rate (cost of capital)
Current Dollar Cost. \% Ret. \% 10.34 .6

$9.8 \quad 1.0$

13.8

6.2

11.8
Constant Dollar Cost. \% Ret. \%

$\begin{array}{ll}5.6 & 2.5 \\ & \end{array}$

5.10 .5

$8.9 \quad 4.0$

Inflation rate, $\%$ per year

Real Escalation rates (over inflation)

Fuel, \% per year

0.5

Operating \& Maintenance, \% per year

0.0 
Assessment of Coal Gasification/Hot Gas

Cleanup Based Advanced Gas Turbine Systems

Appendix B of Greenfield Assessment

\section{COST OF ELECTRICITY}

The approach to determining the cost of electricity is based upon the methodology described in the Technical Assessment Guide, published by the Electric Power Research Institute, Volume I, EPRI-4463-SR, December 1986. The cost of electricity is stated in terms of 10 th-year levelized dollars.

Current \$

0.169

Operating \& Mainienance, 10th year

Capital Carrying Charge, 10th year

Fuel, 10th year

Levelizing Factors

1.234

mills/kWh

Constant $\$$

0.113

1.000

Cost of Electricity - Levelized

Capital Charges

Fuel costs

Operating \& Mainteuance 
TABLE B-2

GREENFIELD/HOT GAS CLEANUP CASE $>$

231.7 MW POWER PLANT

CAPITAL REQUIREMENTS (Mid-1990 Dollars)

Total Plant Investment

Area

No. Plant Section Description

100 Coal Receiving, Handling \& Prep

150 Limestone Receiving, Hand \& Pre

250 Booster Compression

300 KRW Gasification

380 Recycle Gas Compression

400 Gas Conditioning

500 External Desulfurization

600 Sulfation

700 Sulfuric Acid Plant

900 Gas Turbine System

1000 HRSG System

1100 Steam Turbine System

1200 Ash \& Fines Handling \& Disp

1300 General Facilities
Process

Cont. K\$

$\$ 0$

$\$ 0$

$\$ 0$

$\$ 2,654$

$\$ 736$

$\$ 2,486$

$\$ 796$

$\$ 1,132$

$\$ 0$

$\$ 1,860$

$\$ 671$

$\$ 0$

$\$ 0$

$\$ 0$
Cost, $\mathrm{K} \$$

W/O Cont

$\$ 15,519$

$\$ 9,311$

$\$ 4,450$

$\$ 28,643$

$\$ 7,054$

$\$ 17,819$

$\$ 10,213$

$\$ 7,062$

$\$ 0$

$\$ 36,453$

$\$ 13,169$

$\$ 25,875$

$\$ 8,161$

Subtotal, Process Plant Cost

$\$ 183,729$

General Plant Facilities

$\$ 29,942$

$\$ 21,630$

$\$ 10,335$

$\$ 49,127$

Process Contingency (Using contingencies listed above)

$\$ 294,763$ Total Plant Cost (TPC)

$\$ 52,400$

$\$ 347,163$

Total Plant Investment (TPI)

$\$ 1,094$

$\$ 5,322$

$\$ 8,850$

$\$ 5,751$

$\$ 4,957$

$\$ 2,828$

Land, 435 Acres

$\$ 375,965$ 


\section{ANNUAL OPERATING COSTS}

Capacity Factor $=65 \%$

Cost Item

Quantity

Ill. No. 6 Coal Fuel Type

Consumable Materials

Limestone

Nahcolite

Zinc Ferrite

Miscellaneous

Ash/Sorbent Disposal Costs

Plant Labor

Oper Labor (incl benef)

Supervision \& Clerical

Maintenance Costs

Insurance \& Local Taxes

Royalties

Other Operating Costs

Total Operating Costs

By-Product Credits

Total By-Product Credits

$0.0 \mathrm{~T} / \mathrm{D}$

$42.3 \mathrm{~T} / \mathrm{D}$

$2.4 \mathrm{~T} / \mathrm{D}$

$0.6 \mathrm{~T} / \mathrm{D}$ $1517.7 \mathrm{~T} / \mathrm{D}$

$615.0 \mathrm{~T} / \mathrm{D}$

$17 \mathrm{Men} / \mathrm{shift}$

$2026.6 \mathrm{~T} / \mathrm{D}$

$\$ 35.00 / \mathrm{T}$

$\$ 16,828$

Unit \$

Annual

Price

Cost. K\$

$\$ 1,441$

$\$ 148$

$\$ 824$

$\$ 360$

$\$ 1.00 / \mathrm{T}$

$\$ 2.94 / \mathrm{T}$

$\$ 429$

$\$ 21.80 / \mathrm{Hr}$.

$\$ 3,238$

$\$ 1,222$

$\$ 5,167$

$\$ 1,769$

$\$ 0$

$\$ 407$

$\$ 31,834$

$\$ 0$

$\$ 0$

$\$ 31,834$

Net Operating Costs 
BASES AND ASSUMPTIONS

\section{A. CAPITAL BASES AND DETAILS}

Initial Catalyst Inventory

Gasification

Initial Chemicals Inventory

Miscellaneous

Total Catalyst and Chemical Inventory

lb.
QUANTITY UNIT \$ PRICE COST, K\$

/lb.

$\$ 5,292$

$\$ 1.00 / \mathrm{lb}$.

$\$ 30$

$\$ 5,322$

$\$ 6,943$

$\$ 1,375$

$\$ 532$

$\$ 8,850$

$2 \%$ TPI
Total Startup Costs

Operating costs

Fuel

Working capital

Fuel \& Consumables inv, 60 days supply

By-Product inventory, 30 days supply

Direct expenses, 0 days

Total Working Capital

\section{B. ECONOMIC ASSUMPTIONS}

Project life

Book life

Tax life

Federal and state income tax rate

Tax depreciation method

Investment Tax Credit
30 Years

30 Years

20 Years

$37.7 \%$

ACRS

$0.0 \%$

Financial structure

\begin{tabular}{|c|c|c|c|c|c|}
\hline Type of Security & \%o ofTotal & \multicolumn{2}{|c|}{$\begin{array}{l}\text { Current Dollar } \\
\text { Cost \% Ret. \% }\end{array}$} & \multicolumn{2}{|c|}{$\begin{array}{l}\text { Constant Dollar } \\
\text { Cost. \% Ret. \% }\end{array}$} \\
\hline Debt & 45 & 10.3 & 4.6 & 5.6 & 2.5 \\
\hline Preferred Stock & 10 & 9.8 & 1.0 & 5.1 & 0.5 \\
\hline Common Stock & 45 & 13.8 & 6.2 & 8.9 & 4.0 \\
\hline \multicolumn{2}{|c|}{ Discount rate (cost of capital) } & & 11.8 & & 0 \\
\hline
\end{tabular}

Inflation rate, \% per year

Real Escalation rates (over inflation)

Fuel, \% per year

Operating \& Maintenance, \% per year 


\section{COST OF ELECTRICITY}

The approach to determining the cost of electricity is based upon the methodology described in the Technical Assessment Guide, published by the Electric Power Research Institute, Volume I, EPRI-4463-SR, December 1986. The cost of electricity is stated in terms of 10 th-year levelized dollars.

Levelizing Factors

Capital Carrying Charge, 10th year

Fuel, 10th year

Current \$

Constant \$

Operating \& Maintenance, 10th year

0.169

0.113

1.265

1.025

1.234

1.000

Cost of Electricity - Levelized

Capital Charges

mills/kWh

mills/kWh

Fuel costs

Operating \& Maintenance

48.1

32.3

16.1

13.1

14.0

11.4

Total Cost of Electricity

78.3

56.8 
Table B-3

Greenfield/Hot Gas Cleanup Case 6

409.6 MW Power Plant

Capital Requirements (Mid-1990 Dollars)

Total Plant Investment

Area

No. Plant Section Description

100 Coal Receiving, Handling \& Prep

150 Limestone Receiv'g, Hand \& Pre

250 Booster Compression

300 KRW Gasification

380 Recycle Gas Compression

400 Gas Conditioning

500 External Desulfurization

600 Sulfation

700 Sulfuric Acid Plant

900 Gas Turbine System

000 HRSG System

1100 Steam Turbine System

1200 Ash \& Fines Handling \& Disp

1300 General Facilities
Process

Cont, K\$

$\$ 0$

$\$ 0$

$\$ 0$

$\$ 6,358$

$\$ 619$

$\$ 1,925$

$\$ 0$

$\$ 3,488$

$\$ 0$

$\$ 3,629$

$\$ 1,277$

$\$ 0$

$\$ 0$

$\$ 0$

Cost, $\mathrm{K} \$$

W/O Cont

$\$ 22,966$

$\$ 10,276$

$\$ 7,933$

$\$ 40,622$

$\$ 5,855$

$\$ 12,740$

$\$ 0$

$\$ 21,383$

$\$ 0$

$\$ 71,078$

$\$ 25,028$

$\$ 42,128$

$\$ 12,451$

$\$ 0$

$\$ 272,460$

$\$ 39,315$

$\$ 38,418$

$\$ 17,296$

$\$ 73,498$

$\$ 440,987$

$$
\text { Total Plant Cost (TPC) }
$$

$\$ 81,496$

Plant Construction Period, 5 Years (1 or more)

Construction Interest Rate, $11.8 \%$

Adjustment for Interest and Inflation

$\$ 522,483$

Total Plant Investment (TPI)

$\$ 1,644$

$\$ 59$

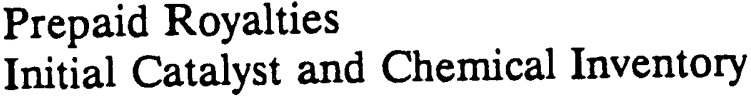

$\$ 12,993$

Startup Costs

Spare Parts

$\$ 6,318$

Working Capital

$\$ 7,688$

$\$ 2,828$

Land, 435 Acres

Total Capital Requirement (TCR) 


\section{ANNUAL OPERATING COSTS}

Capacity Factor $=65 \%$

Cost Item

Ill. No. 6 Coal Fuel Type

Consumable Materials

Limestone

Nahcolite

Zinc Ferrite

Miscellaneous

Ash/Sorbent Disposal Costs

Plant Labor

Oper Labor (incl benef)

Supervision \& Clerical

Maintenance Costs

Insurance \& Local Taxes

Royalties

Other Operating Costs

Total Operating Costs

By-Product Credits

$0.0 \mathrm{~T} / \mathrm{D}$

$44.7 \mathrm{~T} / \mathrm{D}$

$0.0 \mathrm{~T} / \mathrm{D}$

$0.0 \mathrm{~T} / \mathrm{D}$

$2963.5 \mathrm{~T} / \mathrm{D}$

$798.0 \mathrm{~T} / \mathrm{D}$

$21 \mathrm{Men} / \mathrm{shift}$

$\$ 21.80 / \mathrm{Hr}$.

$\$ 11.20 / \mathrm{T}$

$\$ 261.25 / \mathrm{T}$

$\$ 6,270 / \mathrm{T}$

$\$ 1.00 / \mathrm{T}$

$\$ 2.94 / \mathrm{T}$

$\$ 557$

$\$ 3,999$

$\$ 1,577$

$\$ 7,472$

$\$ 2,646$

$\$ 0$

$\$ 526$

$\$ 47,174$

Total By-Product Credits

Net Operating Costs

Cost, K\$

$\$ 28,513$

$\$ 1,182$

$\$ 0$

$\$ 0$

.

Annual

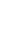




\section{BASES AND ASSUMPTIONS}

\section{A. CAPITAL BASES AND DETAILS}

\section{QUANTITY UNIT \$ PRICE COST, K\$}

Initial Catalyst Inventory

Gasification

Initial Chemicals Inventory

Miscellaneous
- lb.

$59000 \mathrm{lb}$. /lb.

$\$ 1.00 / \mathrm{lb}$.

$\$ 59$

Total Catalyst and Chemical Inventory

Startup costs

Plant modifications, 2\% TPI

$\$ 10,450$

Operating costs

Fuel

Total Startup Costs

Working capital

Fuel \& Consumables inv, 60 days supply

By-Product inventory, 30 days supply

$\$ 0$

Direct expenses, 0 days

$\$ 0$

Total Working Capital

$\$ 7,688$

\section{B. ECONOMIC ASSUMPTIONS}

Project life

Book life

Tax life

Federal and state income tax rate

Tax depreciation method

Investment Tax Credit
30 Years

30 Years

20 Years

$37.7 \%$

ACRS

$0.0 \%$

Financial structure

Type of Security

Debt

Preferred Stock

Common Stock

Discount rate (cost of capital) 45

10

45

)

Current Dollar Constant Dollar

\section{$\%$ ofTotal}

Cost. \%

10.3

9.8

13.8
Ret.\%

Cost. \%

5.6

Ret. \%

1.0

5.1

6.2

8.9

11.8

4.5

Inflation rate, $\%$ per year

0.5

Fuel, \% per year

0.0 
Assessment of Coal Gasification/Hot Gas

Cleanup Based Advanced Gas Turbine Systems

Appendix B of Greenfield Assessment

\section{COST OF ELECTRICITY}

The approach to determining the cost of electricity is based upon the methodology described in the Technical Assessment Guide, published by the Electric Power Research Institute, Volume I, EPRI-4463-SR, December 1986. The cost of electricity is stated in terms of 10 th-year levelized dollars.

Levelizing Factors

Current \$

Capital Carrying Charge, 10th year Fuel, 10th year

Operating \& Maintenance, 10th year

Cost of Electricity - Levelized

Capital Charges

Fuel costs

Operating \& Maintenance

Total Cost of Electricity
0.169

1.265

1.234

mills/kWh

40.1

15.5

9.9

65.5
Constant \$

0.113

1.025

1.000

mills/kWh

26.9

12.5

8.0

47.5 

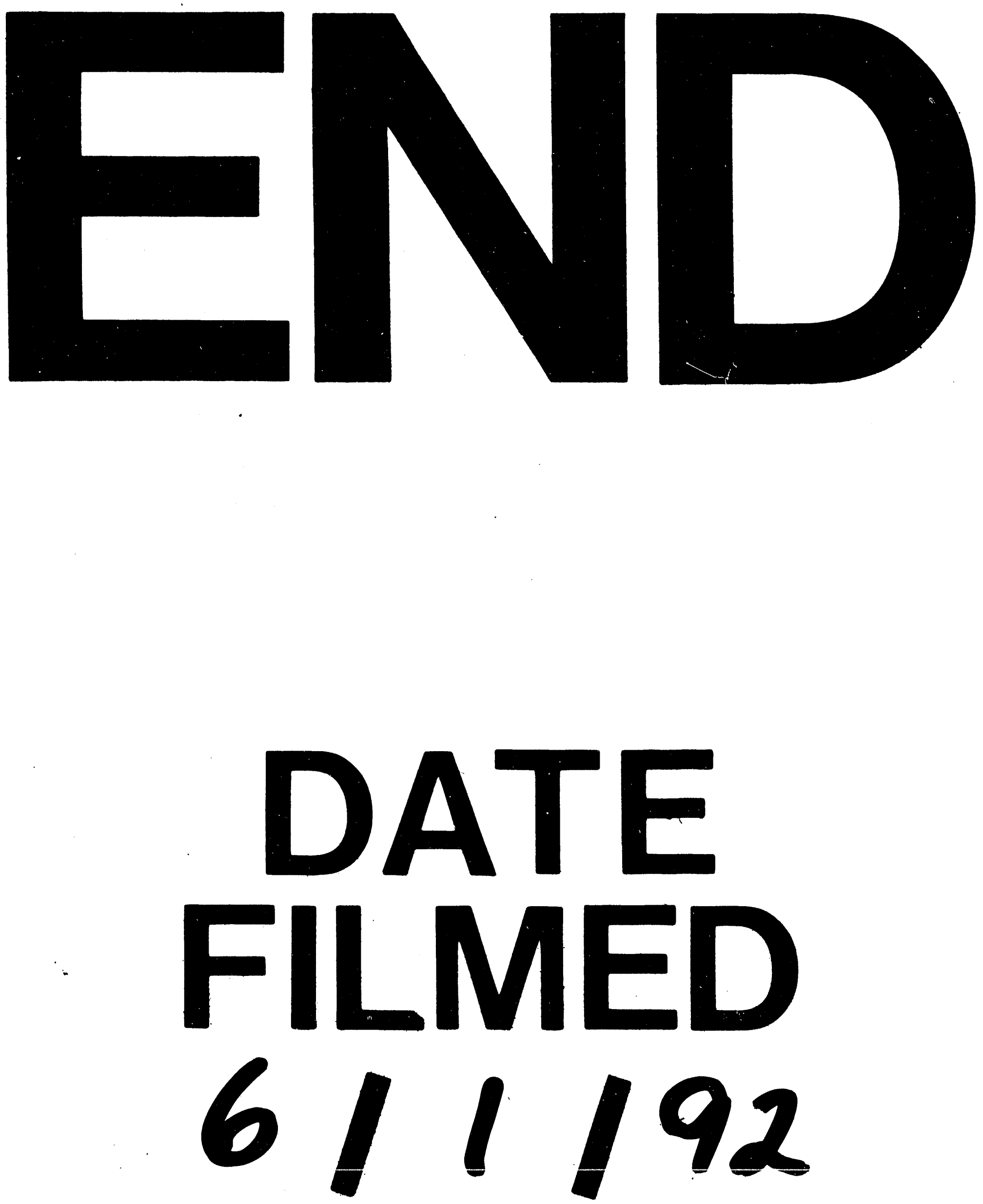
